\title{
Generic Assignments, Strain Histories and Properties of Pure Cultures of Cyanobacteria
}

\author{
By ROSMARIE RIPPKA, JOSETTE DERUELLES, \\ JOHN B. WATERBURY, ${ }^{*}$ MICHAEL HERDMAN† AND \\ ROGER Y. STANIER \\ Unité de Physiologie Microbienne, Département de Biochimie et Génétique Microbienne, \\ Institut Pasteur, 28 rue du Docteur Roux, Paris 75015, France
}

(Received 8 June 1978)

\begin{abstract}
On the basis of a comparative study of 178 strains of cyanobacteria, representative of this group of prokaryotes, revised definitions of many genera are proposed. Revisions are designed to permit the generic identification of cultures, often difficult through use of the field-based system of phycological classification. The differential characters proposed are both constant and readily determinable in cultured material. The 22 genera recognized are placed in five sections, each distinguished by a particular pattern of structure and development. Generic descriptions are accompanied by strain histories, brief accounts of strain properties, and illustrations; one or more reference strains are proposed for each genus. The collection on which this analysis was based has been deposited in the American Type Culture Collection, where strains will be listed under the generic designations proposed here.
\end{abstract}

\section{INTRODUCTION}

The cyanobacteria constitute one of the largest sub-groups of Gram-negative prokaryotes. As a result of their traditional assignment to the algae, the classification of these organisms was developed by phycologists, working under the provisions of the Botanical Code (Stafleu et al., 1972). Almost entirely on the basis of observations on field materials, about 150 genera and well over 1000 species have been described. The discriminatory properties, both generic and specific, are either structural or ecological, these being virtually the only characters determinable in the field. Types are represented by herbarium specimens or, failing these, by descriptions and illustrations; cultures are not recognized as valid type materials under the Botanical Code.

The attempt to identify cyanobacteria in culture through this field-based system of classification leads to many difficulties and ambiguities. The limited and necessarily provisional taxonomic goal of the present article is to redefine certain cyanobacterial genera in such a way that simple and clear-cut generic assignments can be made for cultures. It is based on our experience over the past decade with pure strains representative of all major sub-groups of cyanobacteria. As far as possible, we have attempted to maintain the system of generic nomenclature and the generic definitions now used by phycologists (Bourrelly, 1970; Geitler, 1932; Desikachary, 1959). However, when the discriminatory characters that nominally distinguish two genera are either not determinable on cultures or within the range of variation of a single strain, the existing genera have been combined. Some of the proposed generic definitions include discriminatory characters that have not hitherto received taxo-

\footnotetext{
* Present address: Biology Department, Woods Hole Oceanographic Institution, Woods Hole, Massachusetts 02543, U.S.A.

$\dagger$ Present address: Department of Biological Sciences, The University, Dundee DD1 4HN.
}

0022-1287/79/0000-8209\$02.00 (C) 1979 SGM

Vol. 110, No. 2 was issued 15 February 1979 
nomic recognition because they were discovered only through investigations of cultures. The present article also presents full strain histories and succinct surveys of outstanding properties of strains assigned to each genus.

The cyanobacterial collection on which this study was based, hereafter termed the Pasteur Culture Collection, has recently been deposited in the American Type Culture Collection, where the strains will be carried under the generic designations proposed here.

Specific names have been applied to only two strains: those on which descriptions of the type species of two monotypic genera, Chlorogloeopsis (Mitra \& Pandey, 1966) and Gloeobacter (Rippka et al., 1974), are based. Under the rules of the Bacteriological Code (Lapage et al., 1975), both strains would be holotypes; under the Botanical Code (Stafleu et al., 1972), only Chlorogloeopsis has nomenclatural status.

The reasons which have led us not to attach specific names to strains of other genera deserve brief discussion. The most important has been the difficulty of making unambiguous identifications in the complete absence of living type materials. This problem is further compounded by the very large number of nomenspecies (frequently associated with descriptions having minimal information content) that already exist in many genera of cyanobacteria. In a recent taxonomic review of two genera of unicellular cyanobacteria, Synechococcus and Synechocystis, Komarek (1976) accepts as valid 39 species in the former genus and 17 in the latter. The species are distinguished primarily by the dimensions of the cell (rod-shaped in Synechococcus, spherical in Synechocystis), in some cases supplemented by information about habitat. Since cell dimensions may vary with culture conditions, and information concerning the habitat is often lacking, culture-based studies on cyanobacterial speciation cannot be satisfactorily fitted into the present nomenclatural framework, even if specific entities can be well characterized both genetically and phenetically. The Botanical Code (Stafleu et al., 1972) provides no remedy, since types are considered immutable. On the other hand, the recognition that living type materials are indispensable for culture-based taxonomic research has led to inclusion in the Bacteriological Code of Rule 18h (revision of 1976), specifically designed to deal with this problem. Under Rule $18 \mathrm{~h}$, a bacterial type represented by a herbarium specimen, description or illustration can be replaced by a subsequently isolated culture of the organism in question, which thereafter becomes the holotype. Under the provision of Rule $18 \mathrm{~h}$ (which was not in effect in 1974), cultures. of myxobacteria (McCurdy, 1974) would have constituted holotypes, rather than representative strains.

A proposal to bring cyanobacteria under the rules of the Bacteriological Code has recently been submitted to the Judicial Commission (Stanier et al., 1978). If successful, this change of jurisdiction would permit the progressive replacement of the existing dead type materials by living holotypes. As an interim measure, one (or sometimes more) reference strains have been designated for the genera recognized here. These have been selected because they appear to be reasonably typical of the genera in question, although they do not necessarily represent or closely resemble the type species. Reference strains lack nomenclatural standing, even under the Bacteriological Code (Lapage et al., 1975), but may be useful for comparative cultural studies as long as living type materials are unavailable.

\section{METHODS}

Abbreviations. P, Pure culture; I, impure culture; ATCC, American Type Culture Collection; PCC, Pasteur Culture Collection; UTEX, Culture Collection of Algae at the University of Texas (formerly IUCC, Indiana University Culture Collection); CCAP, Culture Collection of Algae and Protozoa, Cambridge, England; SAUG, Sammlung von Algenkulturen am Pflanzenphysiologischen Institut der Universität, Göttingen, German Federal Republic.

Organisms. A majority of the cyanobacterial strains of the Pasteur Culture Collection 
were isolated and purified over the last 15 years by past or present members of our research group. Such strains are identified only by a generic name, a PCC number and an ATCC number. Other strains were received either from algal culture collections or from other investigators, often as impure cultures. After purification, such strains were assigned PCC numbers and incorporated into the collection. In the histories of strains received from these sources, the names and/or strain designations which they bore prior to accession to the PCC have been included where the information was available and the purity of cultures checked upon receipt.

Maintenance media and conditions of cultivation. All strains are maintained under photoautotrophic growth conditions in one of the media listed in Table 1. Medium BG-11 and its variant BG-11 $1_{0}$ (BG-11 with omission of $\mathrm{NaNO}_{3}$ ) are used for strains of freshwater, soil or thermal origin and for some strains isolated from marine source materials which do not display the ionic requirements characteristic of indigenous marine cyanobacteria (Stanier \& Cohen-Bazire, 1977). All strains which fix nitrogen aerobically, i.e. heterocystous cyanobacteria and members of the unicellular genus Gloeothece, are maintained in BG-11 $1_{0}$. It was noted that prolonged maintenance of heterocystous cyanobacteria in BG-11 sometimes leads to the selection of mutants which have lost the ability to fix nitrogen aerobically and which either form abnormal heterocysts or, more rarely, have become aheterocystous.

Most cyanobacteria from marine sources cannot grow in BG-11, even if it is supplemented with $3 \%(\mathrm{w} / \mathrm{v}) \mathrm{NaCl}$; analysis of their nutritional properties (Stanier \& Cohen-Bazire, 1977) showed that such cyanobacteria, hereafter defined as marine strains, have elevated requirements for $\mathrm{Na}^{+}, \mathrm{Cl}^{-}, \mathrm{Mg}^{2+}$ and $\mathrm{Ca}^{2+}$. Most of them are maintained in medium $\mathrm{MN}$, which has a natural seawater base and is supplemented with the minerals of medium BG-11 at half strength. Some marine strains grow poorly on $\mathrm{MN}$ and are maintained in a synthetic seawater medium, ASN-III. These are: PCC 7302, 7303, 7304, 7305, 7306, 7345, 7310 and 7418.

A few strains have an absolute requirement for vitamin $B_{12}$, and these are cultivated in the appropriate maintenance medium containing $10 \mu \mathrm{g}$ vitamin $1^{-1}$ (filter-sterilized).

Solid media are prepared by mixing a separately autoclaved aqueous solution of Difco Bacto-agar with the mineral medium, to give a final agar concentration of $1 \%(\mathrm{w} / \mathrm{v})$ (Allen, 1968). Nearly all cyanobacteria grow well on agar and appear to remain viable longer on solid than in liquid media, provided that cultures are kept at low light intensities. We therefore recommend agar slants for routine maintenance.

Stock cultures are grown under continuous illumination with Osram Fluorescent White or Osram L Interna lamps, at a relatively low intensity ( $<500$ lux). Higher intensities should be avoided, since many strains (particularly those containing phycoerythrin) are lightsensitive. With the exception of strains of thermal origin, stock cultures are incubated at $25^{\circ} \mathrm{C}$. For convenience, thermal strains are kept at $37^{\circ} \mathrm{C}$, even though this temperature is close to their minimum for growth. Many cyanobacteria die rapidly when placed at 0 to $4{ }^{\circ} \mathrm{C}$; cultures should therefore never be stored in a refrigerator. Other aspects of cultivation have been discussed previously (Stanier et al., 1971).

It should be emphasized that the media and conditions described above have been selected for their simplicity and convenience in the maintenance of a large and diverse collection. The determination of optimal growth conditions is a different problem, which requires separate study for each strain.

Control of purity. The presence of contaminating bacteria can nearly always be detected by microscopic examination, particularly of old cultures. As a routine control of purity, a heavy streaking on two media is recommended: the solidified maintenance medium, supplemented with $0.2 \%(\mathrm{w} / \mathrm{v})$ glucose and $0.02 \%$ Casamino acids; and nutrient agar. Both should be incubated in the dark at 25 to $30^{\circ} \mathrm{C}$.

Characterization of strains: structural properties. The structural properties on which generic definitions are based are, with one exception, determinable by light microscopy. The 


\section{Table 1. Composition of standard mineral media}

\begin{tabular}{|c|c|c|c|}
\hline \multirow[b]{2}{*}{ Ingredient } & \multicolumn{3}{|c|}{ Amount $\left(\mathrm{g} \mathrm{l}^{-1}\right)$ in medium } \\
\hline & BG-11 & $\mathrm{MN}$ & ASN-III \\
\hline $\mathrm{NaCl}$ & - & - & $25 \cdot 0$ \\
\hline $\mathrm{MgCl}_{2} \cdot 6 \mathrm{H}_{2} \mathrm{O}$ & - & - & $2 \cdot 0$ \\
\hline $\mathrm{KCl}$ & - & - & 0.5 \\
\hline $\mathrm{NaNO}_{3}$ & $1 \cdot 5$ & 0.75 & $0 \cdot 75$ \\
\hline $\mathrm{K}_{2} \mathrm{HPO}_{4} \cdot 3 \mathrm{H}_{2} \mathrm{O}$ & 0.04 & 0.02 & 0.02 \\
\hline $\mathrm{MgSO}_{4} \cdot 7 \mathrm{H}_{2} \mathrm{O}$ & 0.075 & 0.038 & $3 \cdot 5$ \\
\hline $\mathrm{CaCl}_{2} \cdot 2 \mathrm{H}_{2} \mathrm{O}$ & 0.036 & 0.018 & 0.5 \\
\hline Citric acid & 0.006 & 0.003 & 0.003 \\
\hline Ferric ammonium citrate & 0.006 & $0 \cdot 003$ & 0.003 \\
\hline EDTA (disodium magnesium salt) & 0.001 & 0.0005 & 0.0005 \\
\hline $\mathrm{Na}_{2} \mathrm{CO}_{3}$ & 0.02 & 0.02 & 0.02 \\
\hline Trace metal mix A5 + Co* & $1 \mathrm{ml} \mathrm{l}^{-1}$ & $1 \mathrm{ml} \mathrm{l}^{-1}$ & $1 \mathrm{ml} \mathrm{l}^{-1}$ \\
\hline Sea water & - & $750 \mathrm{ml}$ & - \\
\hline Deionized water & $1000 \mathrm{ml}$ & $250 \mathrm{ml}$ & $1000 \mathrm{ml}$ \\
\hline $\mathrm{pH}$ after autoclaving and cooling & $7 \cdot 4$ & $8 \cdot 3$ & $7 \cdot 5$ \\
\hline
\end{tabular}

* Trace metal mix A5+Co contains $\left(\mathrm{g} \mathrm{l}^{-1}\right): \mathrm{H}_{3} \mathrm{BO}_{3}, 2 \cdot 86 ; \mathrm{MnCl}_{2} .4 \mathrm{H}_{2} \mathrm{O}, 1 \cdot 81 ; \mathrm{ZnSO}_{4} .7 \mathrm{H}_{2} \mathrm{O}, 0.222$; $\mathrm{Na}_{2} \mathrm{MoO}_{4} .2 \mathrm{H}_{2} \mathrm{O}, 0.390 ; \mathrm{CuSO}_{4} .5 \mathrm{H}_{2} \mathrm{O}, 0.079 ; \mathrm{Co}\left(\mathrm{NO}_{3}\right)_{2} .6 \mathrm{H}_{2} \mathrm{O}, 0.0494$.

exception is the absence of thylakoids, characteristic of Gloeobacter; this property can only be determined by electron microscopy (Rippka et al., 1974). Although a certain amount of information can be derived from the light microscopic examination of mass cultures, semicontinuous observations of development on agar media are often necessary to reveal determinatively important developmental properties, such as planes of successive divisions, formation of baeocytes, and formation and structure of hormogonia. The Cooper dish culture technique (Waterbury \& Stanier, 1978) is particularly useful for the study of the two former properties, although it cannot be successfully applied to some small-celled cyanobacteria as a result of its optical limitations. In such cases, slide culture techniques (Allen \& Stanier, 1968) must be used.

Many filamentous cyanobacteria (Sections III to V) form motile hormogonia structurally distinguishable from the vegetative filaments. The formation of motile hormogonia can be followed by inoculating material on the centre of an agar plate, and examining at intervals of 2 to $3 \mathrm{~d}$ the filaments in the expanding peripheral region, where hormogonia are enriched as a result of their gliding movement. With highly motile cyanobacteria, gliding motility is also readily evident in wet mounts, prepared by crushing a small piece of agar from a plate culture under a coverslip; the crushed agar provides a substrate which facilitates gliding movement. However, in organisms of Section II, gliding movement is transient, being displayed only by baeocytes; and in organisms of Section I, it is relatively slow. For such organisms, the phototactic response of plate cultures exposed to unidirectional illumination (Stanier et al., 1971; Waterbury \& Stanier, 1978) is the most reliable method of demonstrating motility.

The structural properties described are those displayed by cultures growing photoautotrophically in the appropriate maintenance medium. The use of medium BG- $11_{0}$ is essential for the characterization of heterocystous cyanobacteria (Sections IV and V), since most of these organisms do not develop heterocysts when cultivated with a combined nitrogen source.

All photomicrographs were taken with a Zeiss Universal microscope, equipped with Neofluar objectives, under bright field or phase contrast illumination.

Characterization of strains: physiological properties. Photoheterotrophy was demonstrated by growth of strains in the light in the appropriate mineral medium, supplemented with an organic substrate and with $10^{-5} \mathrm{M}$-dichlorophenyldimethylurea (Rippka, 1972). Substrates 
tested universally were the carbohydrates glucose, fructose and sucrose $(0 \cdot 3$ to $0.5 \%, \mathrm{w} / \mathrm{v})$. Growth on ribose $(0.5 \%$, w/v), glycerol, acetate and glycollate $(0.1 \%, \mathrm{w} / \mathrm{v})$ was tested for all strains with the exception of members of Section II. Acetate and glycollate did not support photoheterotrophic growth of any strain examined; data on the utilization of carbohydrates are given in the descriptions of strains belonging to each genus.

Most strains incapable of aerobic nitrogen fixation were screened for their ability to synthesize nitrogenase under strictly anaerobic conditions, by a special technique described elsewhere (Rippka \& Waterbury, 1977). This property is noted in strain descriptions.

All cyanobacteria so far examined synthesize chlorophyll $a$ and three blue, water-soluble phycobiliproteins: phycocyanin $\left(\lambda_{\max } 620 \mathrm{~nm}\right)$, allophycocyanin $\left(\lambda_{\max } 650 \mathrm{~nm}\right)$ and allophycocyanin $B\left(\lambda_{\max } 670 \mathrm{~nm}\right)$. With respect to pigmentation, the only property now known to be of determinative significance within the group is the presence or absence of an additional phycobiliprotein with an absorption maximum at a wavelength shorter than that of phycocyanin. Several different chromoproteins of this type have been identified in cyanobacteria (reviewed by Stanier \& Cohen-Bazire, 1977). They include C-phycoerythrin $\left(\lambda_{\max } 550\right.$ to $570 \mathrm{~nm})$; other phycoerythrins, showing an additional peak at a shorter wavelength; and phycoerythrocyanin $\left(\lambda_{\max } 565 \mathrm{~nm}\right.$; shoulder at $\left.590 \mathrm{~nm}\right)$. The presence of such compounds, hereafter termed collectively phycoerythrinoid pigments, can often be detected by determining the absorption spectrum of a crude cell-free extract, or even of a cell suspension; however, a definitive characterization usually requires isolation in a spectrally pure state. In strain descriptions, phycoerythrinoid pigments are tentatively designated as C-phycoerythrin, other phycoerythrins (distinct from C-phycoerythrin) or phycoerythrocyanin.

Techniques for the extraction and purification of DNA, and for the determination of mean DNA base composition, are described by Herdman et al. (1979).

\section{RESULTS AND DISCUSSION}

\section{Primary sub-divisions}

Differences in structure and development permit the recognition among cyanobacteria of five large sub-groups (Table 2). These sub-groups do not, for the most part, correspond precisely to major taxa now recognized by phycologists; they will be described here as sections.

Section I is composed of unicellular organisms that reproduce either by binary fission or by budding; the cells are spherical, cylindrical or oval. These are the simplest cyanobacteria, structurally speaking, and have counterparts in other major groups of Gram-negative, unicellular bacteria.

The members of Section II are characterized by a special type of reproduction - multiple fission - which has not been reported in any other prokaryotic group. They all share one property: the vegetative cell is always enclosed by an additional fibrous layer closely investing the outer membrane layer. Multiple fission (rapid binary fission of a vegetative cell within the fibrous wall layer without accompanying growth) leads to the formation of small, spherical reproductive cells (baeocytes) that are subsequently released by rupture of the fibrous layer of the parental cell wall (Waterbury \& Stanier, 1978). The number of baeocytes produced from one parental cell ranges from 4 to over 1000 . In the phycological literature, the reproductive cell characteristic of members of this section is termed an endospore. The alternative name, baeocyte (Greek: 'small cell'), was recently proposed in order to avoid confusion in the prokaryotic context (Waterbury \& Stanier, 1978). In most members of Section II, synthesis of the fibrous wall layer is repressed during multiple fission, and the baeocytes at the time of their release possess walls that contain only peptidoglycan and outer membrane layers. These baeocytes display gliding motility, but become immotile as their size increases and synthesis of the fibrous wall layer begins. In other members of Section II, synthesis of the fibrous wall layer accompanies multiple fission. Consequently, 
Table 2. Major sub-groups of cyanobacteria

\begin{tabular}{|c|c|c|c|}
\hline \multirow{2}{*}{$\begin{array}{l}\text { Unicellular; cells } \\
\text { single or forming } \\
\text { colonial aggregates } \\
\text { held together by } \\
\text { additional outer } \\
\text { cell wall layers }\end{array}$} & \multicolumn{2}{|c|}{ Reproduction by binary fission or by budding } & Section I \\
\hline & \multicolumn{2}{|c|}{$\begin{array}{l}\text { Reproduction by multiple fission giving rise } \\
\text { to small daughter cells (baeocytes), or by both } \\
\text { multiple fission and binary fission }\end{array}$} & Section II \\
\hline \multirow{3}{*}{$\begin{array}{l}\text { Filamentous; a tri- } \\
\text { chome (chain of } \\
\text { cells) which grows } \\
\text { by intercalary cell } \\
\text { division }\end{array}$} & \multirow{3}{*}{$\begin{array}{l}\text { Reproduction by ran- } \\
\text { dom trichome break- } \\
\text { age, by formation of } \\
\text { hormogonia and } \\
\text { (Sections IV and V } \\
\text { only) sometimes by } \\
\text { germination of } \\
\text { akinetes }\end{array}$} & $\begin{array}{l}\text { Trichome always com- } \\
\text { posed only of vegeta- } \\
\text { tive cells }\end{array}$ & $\begin{array}{l}\text { Division in only one } \\
\text { plane } \\
\text { Section III }\end{array}$ \\
\hline & & \multirow{2}{*}{$\begin{array}{l}\text { In the absence of } \\
\text { combined nitrogen, } \\
\text { trichome contains } \\
\text { heterocysts; some } \\
\text { also produce } \\
\text { akinetes }\end{array}$} & $\begin{array}{l}\text { Division in only one } \\
\text { plane } \\
\text { Section IV }\end{array}$ \\
\hline & & & $\begin{array}{l}\text { Division in more than } \\
\text { one plane } \\
\text { Section } \mathbf{V}\end{array}$ \\
\hline
\end{tabular}

the baeocytes already have a thin fibrous wall layer at the moment of their release. Such baeocytes are never motile. Members of the genera Dermocarpa and Xenococcus divide only by multiple fission. In Dermocarpella, Myxosarcina, Chroococcidiopsis and the Pleurocapsa group, baeocyte enlargement is followed by a series of binary fissions, resulting in the formation of an aggregate of vegetative cells, which remain firmly adherent to one another. Some or all of the cells in the aggregate later undergo multiple fission and release baeocytes.

The unit of structure in cyanobacteria of Sections III to V is a filament of cells, or trichome. Elongation of the trichome is accompanied by an increase in cell number, as a result of repeated intercalary cell divisions. Transverse wall formation occurs through centripetal ingrowth of the peptidoglycan layer, followed by that of the outer membrane layer. The extent to which the outer membrane layer participates in the formation of the transverse walls is evidenced by the degree of constriction between the cells that compose the trichome. Reproduction is effected by breakage of the trichome into shorter lengths. These short, reproductive filaments are often distinguishable from the mature trichome by their gliding motility. Phycologists (e.g. Geitler, 1932) have applied the term hormogonium to any motile trichome fragment released from an immotile, ensheathed parental trichome. This term can now be extended (in the specific context of the heterocystous cyanobacteria) to designate filaments, either motile or immotile, that are distinguishable from the parental trichome by cell size, cell shape, gas vacuolation or the absence of heterocysts, even when grown without a source of combined nitrogen.

The vegetative trichomes of filamentous cyanobacteria are often enclosed by tubular sheaths. If trichome breakage occurs within a sheath, subsequent elongation may result in the protrusion of one or both daughter filaments through the sheath wall, eventually bringing them into angular apposition. This configuration, often evident in ensheathed cyanobacteria belonging to Sections III to V, is termed 'false branching' in order to distinguish it from the 'true' (i.e. dichotomous) branching (Bourrelly, 1970; Geitler, 1932) that is characteristic of most cyanobacteria in Section V.

In cyanobacteria of Section III, the trichome is composed solely of vegetative cells, and is always uniseriate (one cell thick), since cell divisions occur regularly in a plane at right angles to the long axis of the trichome.

The filamentous cyanobacteria of Sections IV and V are collectively distinguished from those of Section III by their capacity for cellular differentiation. In the absence of a combined nitrogen source, a small fraction of the cells in the trichome develop into heterocysts, 
distinguishable from vegetative cells by their thick walls, relatively weak pigmentation and refractile polar granules (Figs 43, 44, 49). When mature, the heterocyst can neither divide nor dedifferentiate; it is the specific cellular site of nitrogen fixation under aerobic conditions (Stewart et al., 1969). Polar granules form near the point(s) of attachment of the heterocyst to adjacent vegetative cells. An intercalary heterocyst thus has a granule at each pole; a terminal heterocyst has a granule at only one pole. Many members of Sections IV and V can also produce thick-walled resting cells known as akinetes (Stanier \& Cohen-Bazire, 1977; Fogg et al., 1973). The development of akinetes (Figs 36, 46, 69, 85) occurs as cultures approach the stationary phase, and it is usually not dependent on the nature of the nitrogen source.

Sections IV and V are distinguished by one basic character: the polarity of successive cell divisions during growth of the trichome. In Section IV, intercalary cell divisions always occur in a plane at right angles to the long axis of the trichome, which is consequently uniseriate and unbranched (though it may display false branching) (Figs 59, 62). In Section $\mathrm{V}$, hormogonia are uniseriate and unbranched at the time of their release. However, as growth proceeds, some cell divisions occur in planes that are not at right angles to the long axis of the trichome. In those members of Section V that retain a filamentous structure throughout growth (Fischerella), the primary trichome becomes partly multiseriate and develops lateral branches which are uniseriate and composed of small cylindrical cells. At this stage in development, the cellular continuity of the primary trichome is often interrupted by the deposition of a fibrous wall layer between adjacent cells (Thurston \& Ingram, 1971; Martin \& Wyatt, 1974); such interruptions of cellular continuity are evidenced by the frequent presence of terminal heterocysts in an intercalary position within the primary trichome (Figs 70, 72, 75). Hormogonia that are initially uniseriate, unbranched and devoid of heterocysts, even in medium BG- $11_{0}$, are formed from the lateral branches. Heterocyst differentiation in a hormogonium is almost invariably intercalary. In the mature trichome, heterocysts are either intercalary, terminal or lateral. Lateral heterocysts possess only one polar granule: they are heterocysts that have differentiated from vegetative cells that divided in a plane parallel to the long axis of the trichome (Figs 75, 76, 95, 96).

In the special case of Chlorogloeopsis, the filamentous structure is lost relatively early in development and the cylindrical cells of hormogonia become rounded and start to divide in several planes. Associated detachment of groups of cells, enclosed in a common sheath, eventually leads to a virtually unicellular (mode of growth (Gloeocapsa-like). Conditions which favour rapid cell division give rise to hormogonia within such cellular aggregates (Figs 91 to 93).

The fundamental difference between Sections IV and V, the polarity of successive cell division, is also expressed in the mode of akinete germination. In members of Section IV, the germination of an akinete gives rise to a new uniseriate trichome by division in only one plane (Figs 47, 55 to 58,69). Rapid cell division of this trichome leads in some genera to the formation of hormogonia as defined here. In Section V, however, germination of an akinete gives rise to a multicellular aggregate by division in several planes. Subsequent division in only one plane leads to hormogonia formation (Chlorogloeopsis; Figs 91 to 93) or to the development of lateral branches (Fischerella; Fig. 76).

\section{Genera of Section I}

The 57 strains of this section are assigned to six form genera, distinguished by the characters shown in Table 3.

Unicellular cyanobacteria with cylindrical to ovoid cells that reproduce by binary transverse fission are placed in three genera: Synechococcus Nägeli 1849, Gloeothece Nägeli 1849 and Gloeobacter Rippka, Waterbury \& Cohen-Bazire 1974.

In Synechococcus, cells occur singly, in pairs or in short chains and are devoid of sheaths (Figs 1,2). Nägeli (1849) proposed another genus, Aphanothece, for organisms like Synecho- 
Table 3. Section I: Unicellular cyanobacteria that divide by binary fission or by budding

\begin{tabular}{|c|c|c|c|}
\hline & Thylakoids absent & $\begin{array}{c}\text { Division in one } \\
\text { plane }\end{array}$ & $\begin{array}{c}\text { Division in two or three } \\
\text { planes }\end{array}$ \\
\cline { 2 - 4 } $\begin{array}{c}\text { Reproduction by } \\
\text { binary fission }\end{array}$ & $\begin{array}{c}\text { Sheath present } \\
\text { Gloeobacter }\end{array}$ & \\
\cline { 2 - 4 } & Thylakoids present & $\begin{array}{c}\text { Sheath present } \\
\text { Gloeothece }\end{array}$ & $\begin{array}{c}\text { Sheath present } \\
\text { Gloeocapsa }\end{array}$ \\
\cline { 3 - 5 } & $\begin{array}{c}\text { Sheath absent } \\
\text { Synechococcus }\end{array}$ & $\begin{array}{c}\text { Sheath absent } \\
\text { Synechocystis }\end{array}$ \\
\hline $\begin{array}{c}\text { Reproduction by } \\
\text { budding }\end{array}$ & Thylakoids present & Chamaesiphon & \\
\hline
\end{tabular}

coccus that develop as irregular aggregates united by a common slime layer. Although many strains of Synechococcus produce considerable quantities of extracellular slime in culture, none develops in the form of aggregates. The maintenance of the genus Aphanothece appears questionable, particularly since Nägeli (1849) himself suggested that it might be united with Synechococcus. A new genus Cyanothece has recently been proposed by Komarek (1976) to accommodate some species hitherto placed in Synechococcus. Its principal distinguishing character is that cells occur either singly or in pairs, but never in chains. Since the extent of chain formation in organisms of the Synechococcus type is strongly dependent on the conditions of culture, Komarek's proposal is not accepted here. The extreme genetic diversity of the strains now included in the form genus Synechococcus is shown by the very wide span of mean DNA base composition (Stanier et al., 1971; Herdman et al., 1979). This character, in conjunction with phenetic properties, may eventually make possible the recognition of additional genera; but to propose a generic split without taking the base compositional data into account appears unwise.

The genus Gloeothece is distinguished from Synechococcus by sheath formation: welldefined laminar sheaths enclose both individual cells and small cell groups that produce characteristic aggregates (Fig. 3). Sheath formation is both stable and constant in culture, being possessed by strains some of which have been maintained for 15 years. The five Gloeothece strains of the collection also share a distinctive physiological property not possessed by any other strains of Section I: the ability to fix nitrogen aerobically (Wyatt \& Silvey, 1969; Rippka et al., 1971). This may eventually prove to be a second discriminatory character of Gloeothece.

The genus Gloeobacter was created (Rippka et al., 1974) for an ensheathed, unicellular cyanobacterium which has the appearance of a small-celled Gloeothece strain by light microscopy (Fig. 4), but shows an ultrastructure unlike that of any other known cyanobacterium. Both thylakoids and typical phycobilisomes are absent from the cells of Gloeobacter. A cytoplasmic membrane of simple contour is the only unit membrane system within the cell, and this bears a cortical layer of phycobiliproteins on its inner surface.

Unicellular cyanobacteria with spherical cells that divide in two or three successive planes at right angles to one another are assigned to either Synechocystis Sauvageau 1892 or Gloeocapsa Kützing 1843.

At least five different genera have been proposed for unicellular, spherical cyanobacteria that do not produce well-defined sheaths. In both Microcystis Kützing 1833 and Aphanocapsa Nägeli 1849 a common slime layer unites the cells into irregular aggregates: cells of Microcystis often contain gas vacuoles, those of Aphanocapsa do not (Geitler, 1932). Planes of successive divisions are not specified. The genera Merismopedia Meyen 1839 and Eucapsis 
Clements \& Shantz 1909 are distinguished by the formation of rectangular plates and cubical packets of cells, respectively; these reflect regular divisions in two or in three planes. The genus Synechocystis Sauvageau 1892 is distinguishable from the preceding four genera by the failure to produce aggregates, cells occurring singly or in pairs. This is the characteristic growth habit in culture of all strains of unsheathed, spherical cyanobacteria in our collection, and Synechocystis therefore appears to be the most appropriate form genus for such organisms (Figs 5, 6).

When cell separation occurs soon after division, the planes of successive divisions cannot be easily determined, as noted by Sauvagcau (1892). However, most strains of Synechocystis appear to divide in two planes at right angles to one another (Stanier et al., 1971; Komarek, 1976; unpublished observations). When cell separation does not occur, the formation in culture of Merismopedia-like aggregates may occasionally occur (Stanier et al., 1971). One strain, PCC 6906, which does not now form aggregates in culture, was observed on first isolation to produce cubical packets of cells, and should therefore divide in three planes. Pending further study, we propose that Synechocystis be defined as comprising unicellular cyanobacteria with spherical cells that divide successively in more than one plane.

Two genera, Gloeocapsa Kützing 1843 and Chroococcus Nägeli 1849, have been proposed for ensheathed cyanobacteria with spherical cells that divide regularly in three planes. These genera are nominally distinguished by the structure of the sheath (relatively loose and wide in Gloeocapsa) and by the shape of cells immediately after division (rounded in Gloeocapsa, hemispherical in Chroococcus). Geitler (1932) has emphasized that it is often difficult to make the generic distinction on field material, and we have had a similar experience with cultures. Within a single strain, both rounded and hemispherical post-divisional cells may be observed. The factor that determines post-divisional cell shape-obviously often a variable character - is probably the degree of compression exerted by the common sheath that encloses the two daughter cells. We consider that only one genus for ensheathed cyanobacteria with spherical cells is required; and in this event, Chroococcus becomes a later synonym of Gloeocapsa (Figs 7,8).

The generic assignment of the two strains in Section I that reproduce by forming successive spherical buds from one pole of the ovoid cell (Waterbury \& Stanier, 1977) presents no problem. This is the mode of reproduction ('exospore formation' in phycological terminology) distinctive of the genus Chamaesiphon Braun \& Grunow 1865 emend. Geitler 1925 (Figs 9, 10).

\section{Genus Synechococcus Nägeli 1849}

Many of the PCC strains were first described by Stanier et al. (1971). The three strains which these authors placed in group IB of Synechococcus (PCC 6802, 6901 and 6903) have been transferred to the genus Pseudanabaena (Section III). One strain which they assigned to group IA (PCC 6605) has been transferred to Chamaesiphon, since it has been found to reproduce by budding (Waterbury \& Stanier, 1977). Four strains of group IA (PCC 6706, 6707, 6708 and 6709) were isolated from the same water sample as PCC 6710 and appear to be identical with it; they have therefore been eliminated from the collection. With the addition of nine strains isolated since the publication of Stanier et al. (1971), Synechococcus is now represented by 28 strains. Two of these (PCC 7335 and 7424) are shown in Figs 1 and 2. The histories of the strains are as follows:

ATCC 27144 PCC.6301 (Stanier et al., 1971). $\stackrel{\text { P }}{\leftarrow}$ M. B. Allen $\stackrel{\text { I }}{\leftarrow}$ W. A. Kratz [Anacystis nidulans (Kratz \& Myers, 1955), strain Tx20 (Stevens \& Myers, 1976)], fresh water, Texas, U.S.A., 1952. Named as Anacystis nidulans in CCAP (1405/1) (Culture Collection of Algae and Protozoa: List of Strains, 1971), SAUG (1402/1) (Koch, 1964) and UTEX (625 and 1550) (Starr, 1964, 1966). 

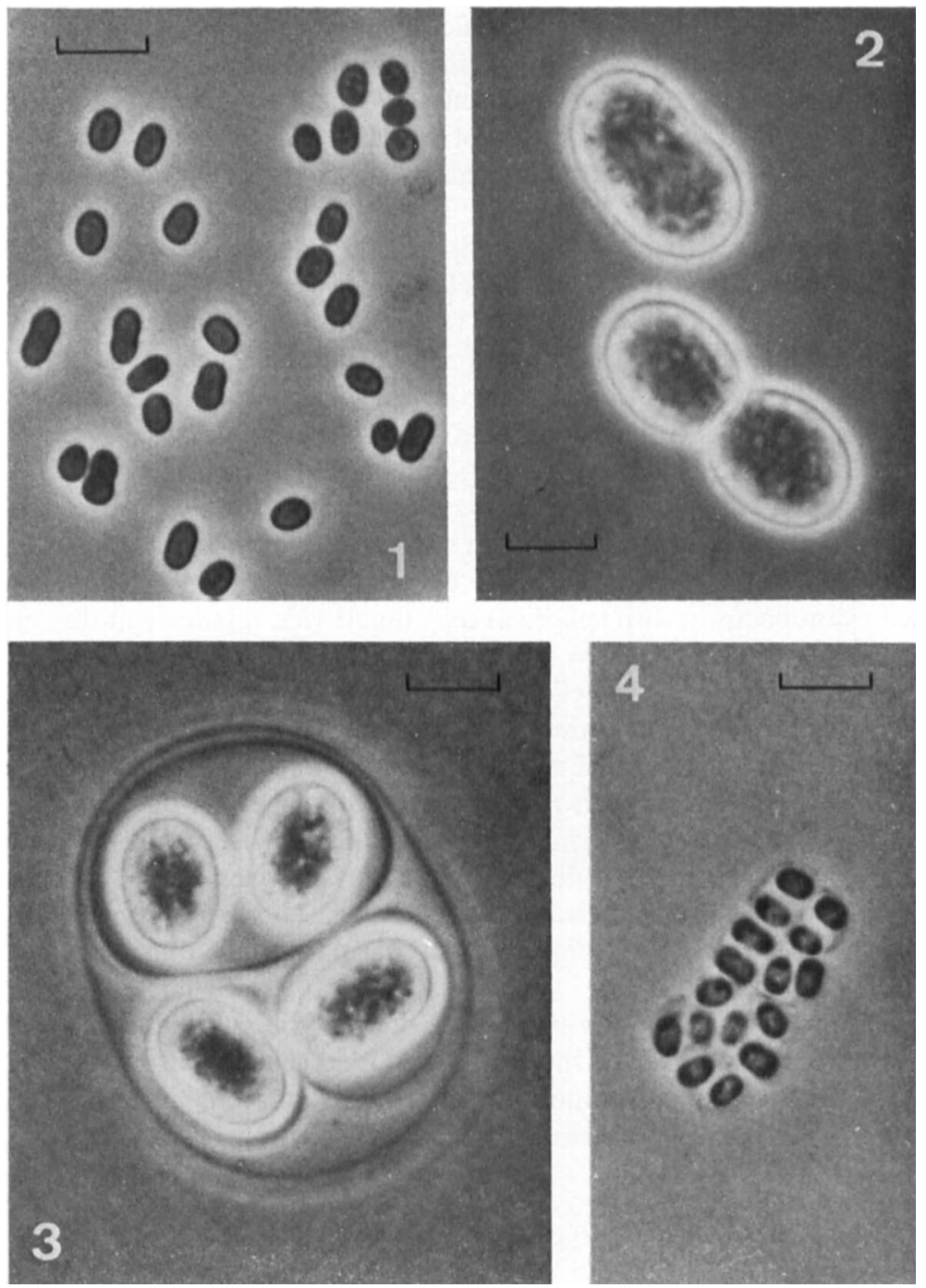

Figs 1 and 2. Synechococcus PCC 7335 and PCC 7424, respectively. Fig. 3. Gloeothece PCC 6909.

Fig. 4. Gloeobacter violaceus PCC 7421. All phase contrast; bar markers represent $5 \mu \mathrm{m}$.

ATCC 27147 PCC 6307 (Stanier et al., 1971). $\stackrel{\mathrm{I}}{\leftarrow}$ G. C. Gerloff (Coccochloris peniocystis 1020), lake water, Wisconsin, U.S.A., 1949 (Gerloff et al., 1950). Named as Coccochloris peniocystis in UTEX (1548) (Starr, 1966).

ATCC 27145 PCC 6311 (Stanier et al., 1971). M. M. Allen, fresh water, California, U.S.A., 1963. Named as Anacystis sp. in UTEX (1549) (Starr, 1966).

ATCC 27167 PCC 6312 (Stanier et al., 1971). M. M. Allen (Anacystis sp.), fresh water, California, U.S.A., 1963.

ATCC 27168 PCC 6603 (Stanier et al., 1971). M. M. Allen, pond water, California, U.S.A., 1966.

ATCC 27174 PCC 6710 (Stanier et al., 1971). R. Kunisawa, fresh water, California, U.S.A., 1967.

ATCC 27177 PCC 6713 (Stanier et al., 1971). R. Kunisawa, fresh water, California, U.S.A., 1967. 
ATCC 27149 PCC 6715 (Stanier et al., 1971). $\stackrel{\text { I }}{\leftarrow}$ D. S. Berns $\stackrel{\text { I }}{\leftarrow}$ D. L. Dyer (Synechococcus lividus), hot spring Yellowstone National Park, U.S.A., 1961 (Dyer \& Gafford, 1961).

ATCC 27179 PCC 6716 (Stanier et al., 1971). $\stackrel{\mathrm{P}}{\leftarrow}$ R. Castenholz (Synechococcus lividus OH-53s), Hunter's Hot Spring, Oregon, U.S.A., 1967 (Castenholz, 1970).

ATCC 27180 PCC 6717 (Stanier et al., 1971). $\stackrel{\mathrm{P}}{\leftarrow}$ R. Castenholz (Synechococcus lividus Y-52s), hot spring, Yellowstone, U.S.A., 1967 (Castenholz, 1970).

ATCC 29138 PCC 6904. A. Neilson, shallow stream, Sierra Valley, California, U.S.A., 1969.

ATCC 27148 PCC 6907 (Stanier et al., 1971). $\stackrel{\text { I }}{\leftarrow}$ UTEX $\stackrel{\text { I }}{\leftarrow}$ E. G. Pringsheim, pond water, Cambridge, England (Pringsheim, 1951). Named as Synechococcus elongatus Naeg. in CCAP (1479/1a) (Culture Collection of Algae and Protozoa: List of Strains, 1971) and UTEX (563) (Starr, 1964).

ATCC 27146 PCC 6908 (Stanier et al., 1971). $\stackrel{\mathrm{r}}{\leftarrow}$ UTEX $\stackrel{\mathrm{I}}{\leftarrow}$ E. B. Gassner $\stackrel{\mathrm{I}}{\leftarrow}$ W. Arnold, source unknown. Named as Synechococcus in UTEX (1191) (Starr, 1964).

ATCC 27191 PCC 6910 (Stanier et al., 1971). $\stackrel{\text { I }}{\leftarrow}$ G. C. Gerloff (Gloeocapsa alpicola 1051), lake water, Wisconsin, U.S.A., 1949; does not correspond to original description (Gerloff et al., 1950).

ATCC 27192 PCC 6911 (Stanier et al., 1971). $\stackrel{\mathrm{I}}{\leftarrow}$ R. Haselkorn $\leftarrow$ R. Safferman $\leftarrow$ P. R. Gorham (Microcystis aeruginosa NRC-1), lake water, Ontario, Canada, 1954; does not correspond to original description (Hughes et al., 1958; Zehnder \& Gorham, 1960).

ATCC 27194 PCC 7001 (Stanier et al., 1971). $\stackrel{\text { P }}{\leftarrow}$ C. Van Baalen (Anacystis marina 6), intertidal mud, City Island, New York, U.S.A., 1961 (Van Baalen, 1962).

ATCC 27264 PCC 7002. $\stackrel{\text { P }}{\leftarrow}$ C. Van Baalen (Agmenellum quadruplicatum PR-6), mud sample from 'fish pens', Magueyes Island, Puerto Rico, 1961 (Van Baalen, 1962).

ATCC 27265 PCC 7003 (Stanier et al., 1971). $\stackrel{\text { }}{\leftarrow}$ C. Van Baalen (Coccochloris elabens 17a), sand sample at edge of clam bed, Greenwich, Connecticut, U.S.A., 1960 (Van Baalen, 1962).

ATCC 29203 PCC 7009. A. Neilson, low salinity brine pond, Newark, California, U.S.A., 1970.

ATCC 29139 PCC 7117. A. Neilson, low salinity brine pond, Port Hedland, Western Australia, 1971.

ATCC 29140 PCC 7202. $\stackrel{\text { I }}{\leftarrow}$ Algothèque du C.N.R.S., Gif-sur-Yvette $\stackrel{\mathrm{I}}{\leftarrow}$ M. Lefèvre, alkaline pond, Chad, 1963. Named as Synechococcus cedrorum in CCAP (1479/2a and 1479/2b) (Culture Collection of Algae and Protozoa: List of Strains, 1971).

ATCC 29403 PCC 7335. J. B. Waterbury, snail shell, intertidal zone, Puerto Penasco, Mexico, 1971.

ATCC 29404 PCC 73109. $\stackrel{\dot{p}}{\leftarrow}$ C. Van Baalen (Agmenellum quadruplicatum BG-1), sea water, City Island, New York, U.S.A., 1961 (Van Baalen, 1962).

ATCC 29534 PCC 7418. $\stackrel{\text { I }}{\leftarrow}$ Y. Cohen (Aphanothece halophitica), Solar Lake, Israel, 1972 (Garlick et al., 1977).

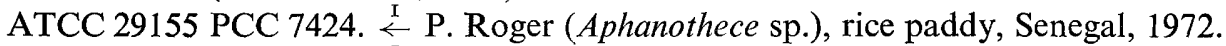

ATCC 29141 PCC 7425. $\stackrel{\text { I }}{\leftarrow}$ P. Roger, rice paddy, Senegal, 1972.

ATCC 29172 PCC 7502. R. Rippka, sphagnum bog, near Kastanienbaum, Vierwaldstättersee, Switzerland, 1972.

ATCC 29154 PCC 7511. R. Rippka, calcareous rock, Aareschlucht, Meiringen, Switzerland, 1972.

The span of mean DNA base composition in Synechococcus extends from 39 to $71 \mathrm{~mol} \%$ GC (Stanier et al., 1971; Herdman et al., 1979); within this range there are three compositional sub-groups with spans of 39 to 43,47 to 56 and 66 to $71 \mathrm{~mol} \%$ GC. However, this 
Table 4. Properties of Synechococcus strains

Mean DNA

base

composition

(mol \% GC)

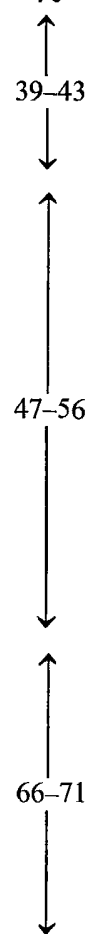

\begin{tabular}{|c|c|c|c|c|}
\hline \multirow[b]{2}{*}{ PCC no.* } & \multicolumn{4}{|c|}{ Facultative photoheterotroph, using: } \\
\hline & Glucose & Fructose & Sucrose & Glycerol \\
\hline 7202 & - & - & - & - \\
\hline 7418 & - & - & - & - \\
\hline 7424 & - & - & - & - \\
\hline 7502 & - & - & - & - \\
\hline 7511 & + & - & + & - \\
\hline 6301) & - & - & - & - \\
\hline 6311$\}$ & - & - & - & - \\
\hline $6908 J$ & - & - & - & - \\
\hline 6312 & - & - & - & - \\
\hline 6715] & - & - & - & - \\
\hline 6716$\}$ & - & - & - & - \\
\hline $6717 J$ & - & - & - & - \\
\hline 6910 & - & - & - & - \\
\hline 7002$\}$ & $(+)$ & - & - & + \\
\hline $73109 f$ & $(+)$ & $(+)$ & - & + \\
\hline 7003 & $(+)$ & - & - & + \\
\hline 7117 & - & - & - & - \\
\hline 7335 & - & + & - & - \\
\hline 7425 & - & - & - & - \\
\hline 6307$)$ & - & - & - & - \\
\hline 6603 & - & - & - & - \\
\hline 6710 & - & - & - & - \\
\hline 6713 & - & - & - & - \\
\hline 6904 & - & - & - & - \\
\hline 6907 & - & - & - & - \\
\hline 6911) & - & - & - & - \\
\hline 7001 & - & - & - & - \\
\hline 7009 & - & - & - & - \\
\hline
\end{tabular}

\section{Synthesis of}

nitrogenase$$
\text { in }
$$

anaerobio

$$
\begin{gathered}
- \\
\text { ND } \\
+ \\
- \\
-
\end{gathered}
$$

Synthesis of C-PE $\dagger$

-
$\overline{+}$
-
-

Marinet:

$$
\begin{aligned}
& - \\
& + \\
& - \\
& -
\end{aligned}
$$$$
-
$$$$
-
$$$$
\text { - }
$$$$
\text { ND }
$$$$
\text { ND }
$$$$
\text { ND }
$$$$
-
$$$$
-
$$$$
\text { - }
$$$$
\begin{aligned}
& - \\
& - \\
& - \\
& - \\
& - \\
& - \\
& - \\
& - \\
& - \\
& - \\
& - \\
& + \\
& - \\
& - \\
& - \\
& - \\
& - \\
& - \\
& - \\
& - \\
& -
\end{aligned}
$$

ND, Not determined; $(+)$, weak growth

* Strains bracketed together are probably independent isolates of the same species.

$\dagger$ C-PE, C-phycoerythrin.

Requirement for high concentrations of $\mathrm{Na}^{+}, \mathrm{Mg}^{2+}$ and $\mathrm{Ca}^{2+}$.

Maximum growth temperature, $53^{\circ} \mathrm{C}$.

$\| \mathrm{o}$, Obligate requirement for vitamin $\mathbf{B}_{12} ; \mathrm{s}$, vitamin $\mathbf{B}_{12}$ stimulates growth, but is not an obligate requirement.
Vitamin $\mathbf{B}_{12}$

require- Cell width

\begin{tabular}{|c|c|}
\hline- & - \\
\hline$+^{s}$ & + \\
\hline- & + \\
\hline- & - \\
\hline- & - \\
\hline- & - \\
\hline- & - \\
\hline- & - \\
\hline- & - \\
\hline- & - \\
\hline- & - \\
\hline- & - \\
\hline- & - \\
\hline$+^{0}$ & - \\
\hline$+^{0}$ & - \\
\hline$+^{0}$ & - \\
\hline- & - \\
\hline- & - \\
\hline- & + \\
\hline- & - \\
\hline
\end{tabular}
ment $\| \quad>3 \mu \mathrm{m}$ 
extreme genetic heterogeneity is mirrored only to a limited extent by known phenotypic properties (Table 4). Most strains possess small cells, less than $2 \mu \mathrm{m}$ wide. Permanent immotility is the rule; only PCC 6910 has been observed to glide (Stanier et al., 1971). The great majority of strains are obligate photoautotrophs. Phycoerythrinoid pigments are produced by only two strains.

Four strain clusters (bracketed in Table 4) are each probably composed of independent isolates belonging to one species.

In view of the diversity in base composition characteristic of this form genus, it appears desirable to designate three reference strains, each representative of one base compositional group.

Reference strains: PCC 7202 for the low GC group

PCC 6301 for the intermediate GC group

PCC 6307 for the high GC group

\section{Genus Gloeothece Nägeli 1849}

One of the five strains assigned to this genus is shown in Fig. 3. Strains PCC 6501 and 6909 were described by Stanier et al. (1971) as Gloeocapsa spp., on the basis of an earlier observation (Allen \& Stanier, 1968) which had suggested that the former strain could divide in more than one plane. Re-examination has shown that PCC 6501 and 6909 divide in only one plane (unpublished observations) and therefore should be assigned to Gloeothece. Three additional Gloeothece strains have since been added to the collection. The histories of the strains are as follows:

ATCC 27151 PCC 6501 (Stanier et al., 1971). $\stackrel{\text { }}{\leftarrow}$ M. M. Allen, fresh water, California, U.S.A., 1965 (Allen \& Stanier, 1968). Named as Gloeocapsa sp. in CCAP $(1430 / 2)$ (Culture Collection of Algae and Protozoa: Second Amendments to the 1971 List of Strains, 1973).

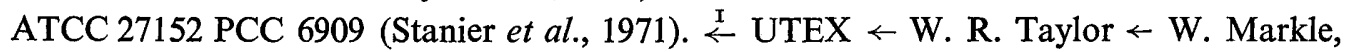
source unknown, 1926. Named as Gloeocapsa sp. in CCAP (1430/3) (Culture Collection of Algae and Protozoa: Second Amendments to the 1971 List of Strains, 1973) and UTEX (795) (Starr, 1964).

ATCC 29163 PCC 7109. J. B. Waterbury, limestone cave, Bermuda, 1971.

ATCC 29116 PCC 73107. R. Rippka, sphagnum bog, near Kastanienbaum, Vierwaldstättersee, Switzerland, 1972.

ATCC 29164 PCC 73108. R. Rippka, sphagnum bog, near Kastanienbaum, Vierwaldstättersee, Switzerland, 1972.

The range of mean DNA base composition is 40 to $43 \mathrm{~mol} \%$ GC (Herdman et al., 1979). Motility has never been observed. All strains are obligate photoautotrophs, and all are capable of fixing nitrogen aerobically. With the exception of PCC 73107, all produce a phycoerythrinoid pigment distinct from C-phycoerythrin.

\section{Reference strain: PCC 6501}

Genus Gloeobacter Rippka, Waterbury \& Cohen-Bazire 1974

Strain PCC 7421, the only representative of this genus so far isolated, is shown in Fig. 4; it has the following history:

ATCC 29082 PCC 7421. R. Rippka, calcareous rock, near Kastanienbaum, Vierwaldstättersee, Switzerland, 1972. Holotype of the type species, Gloeobacter violaceus (Rippka et al., 1974).

This strain has a DNA base composition of $64 \mathrm{~mol} \%$ GC (Rippka et al., 1974), very different from that of Gloeothece strains. It is an immotile, obligate photoautotroph that 

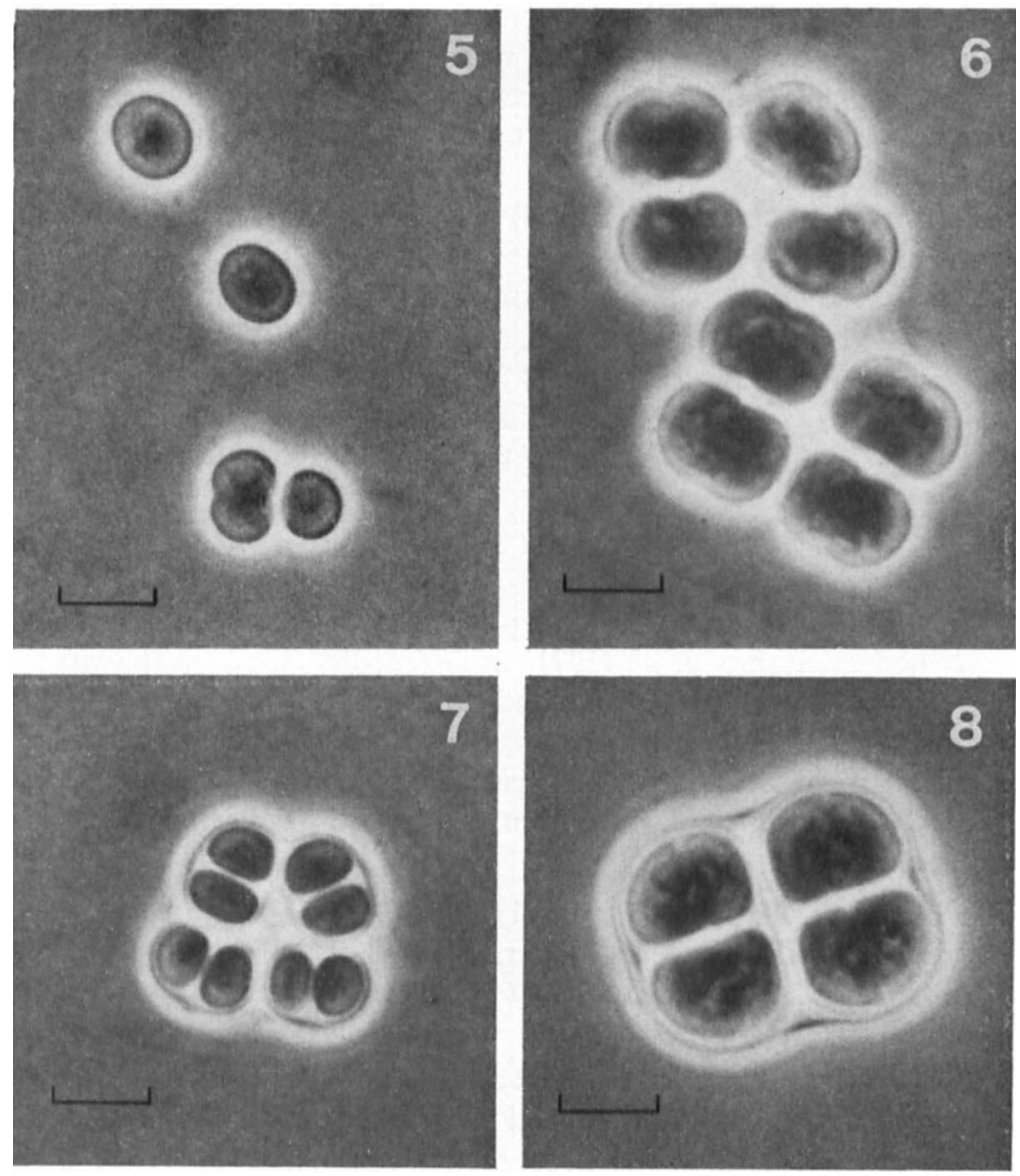

Figs 5 and 6. Synechocystis PCC 7509 and PCC 6808, respectively. Figs 7 and 8. Gloeocapsa PCC 7428 and PCC 73106, respectively. All phase contrast; bar markers represent $5 \mu \mathrm{m}$.

fails to synthesize nitrogenase in anaerobiosis; it produces a phycoerythrinoid pigment distinct from C-phycoerythrin. For further information, see Rippka et al. (1974).

\section{Genus Synechocystis Sauvageau 1892}

Two representatives of Synechocystis are shown in Figs 5 and 6. A majority of the strains of this genus were originally described by Stanier et al. (1971) either as Aphanocapsa (group IIA) or as Microcystis (group IIC). Komarek (1976) pointed out that the strains of group IIA conform to the definition of Synechocystis since they do not normally develop in culture as cell aggregates, an interpretation with which we agree. The one strain of group IIC (PCC 7005) was received by Stanier et al. (1971) from an algal culture collection as Microcystis aeruginosa. The cells, which occur singly, contained phase-bright granules interpreted by Stanier et al. (1971) as gas vacuoles, and on this basis assignment to Microcystis was maintained. However, subsequent work has shown that these granules are not gas vacuoles. Although it cannot be stated categorically that PCC 7005 did not at one time produce gas vacuoles, it has not done so since its purification in 1970 and should therefore be assigned, like the strains of group IIA, to Synechocystis. One of the strains described by Stanier et al. (1971), PCC 6807, has since been lost. Six new strains of this genus (PCC 6902, 6905, 6906, 7008,7201 and 7509) have been added to the collection. The histories of all strains are as follows: 
ATCC 27150 PCC 6308 (Stanier et al., 1971). $\stackrel{\text { I }}{\leftarrow}$ G. C. Gerloff (Gloeocapsa alpicola 1051), lake water, Wisconsin, U.S.A., 1949 (Gerloff et al., 1950). Named as Gloeocapsa alpicola in UTEX (1598) (Starr, 1971) and CCAP (1431/1) (Culture Collection of Algae and Protozoa: List of Strains, 1971).

ATCC 27170 PCC 6701 (Stanier et al., 1971). $\stackrel{\text { P }}{\leftarrow}$ J. Hauxhurst (Aphanocapsa HA), fresh water, California, U.S.A., 1967.

ATCC 27171 PCC 6702 (Stanier et al., 1971). $\stackrel{\text { P }}{\leftarrow}$ J. Hauxhurst (Aphanocapsa HD), fresh water, California, U.S.A., 1967.

ATCC 27175 PCC 6711 (Stanier et al., 1971). R. Kunisawa (Aphanocapsa sp.), California, U.S.A., 1967.

ATCC 27178 PCC 6714 (Stanier et al., 1971). R. Kunisawa (Aphanocapsa sp.), fresh water, California, U.S.A., 1967.

ATCC 27184 PCC 6803 (Stanier et al., 1971). R. Kunisawa (Aphanocapsa sp.), fresh water, California, U.S.A., 1968.

ATCC 27185 PCC 6804 (Stanier et al., 1971). R. Kunisawa (Aphanocapsa sp.), fresh water, California, U.S.A., 1968.

ATCC 27186 PCC 6805 (Stanier et al., 1971). R. Kunisawa (Aphanocapsa sp.), fresh water, California, U.S.A., 1968.

ATCC 27187 PCC 6806 (Stanier et al., 1971). R. Kunisawa (Aphanocapsa sp.), fresh water, California, U.S.A., 1968.

ATCC 27189 PCC 6808 (Stanier et al., 1971). R. Kunisawa (Aphanocapsa sp.), California, U.S.A., 1968.

ATCC 29108 PCC 6902. A. Neilson, brackish water, Oregon, U.S.A., 1969.

ATCC 29109 PCC 6905. A. Neilson, low salinity brine pond, Newark, California, U.S.A., 1569 .

ATCC 27266 PCC 6906. $\stackrel{\text { I }}{\leftarrow}$ J. West (Eucapsis sp.), hypersaline lake, Salton Sea, California, U.S.A., 1969.

ATCC 27153 PCC 7005 (Stanier et al., 1971). $\stackrel{\text { r }}{\leftarrow}$ SAUG $(1450 / 1)($ Koch, 1964) $\leftarrow$ G. C. Gerloff (Microcystis aeruginosa 1036), Lake Mendota, Wisconsin, U.S.A., 1946 (Gerloff et al., 1950, 1952). Named as Microcystis aeruginosa in CCAP (1450/1) (Culture Collection of Algae and Protozoa: List of Strains, 1971).

ATCC 29110 PCC 7008. A. Neilson, shallow pond, Point Reyes Peninsula, California, U.S.A., 1970.

ATCC 29152 PCC 7201. J. B. Waterbury, hemispherical macroscopic colony, bank above high water, Bodega, California, U.S.A., 1970.

ATCC 29235 PCC 7509. R. Rippka, rock scraping, Schöllenen, below Teufelsbrücke, Switzerland, 1972.

Strains of this genus fall into two sub-groups, distinguishable by their mean DNA base composition: 35 to 37 and 42 to $48 \mathrm{~mol} \%$ GC (Stanier et al., 1971; Herdman et al., 1979). All strains of low GC content are obligate photoautotrophs, whereas most strains of high GC content (9 out of 12) are facultative photoheterotrophs (Table 5). The latter include seven strains of independent origin that are similar in all respects and probably represent independent isolates of one species. Some strains in both base compositional groups display gliding motility. Phycoerythrins are produced only by some strains of the low GC group. As for Synechococcus, reference strains representative of each base compositional sub-group are designated. Reference strains: PCC 6308 for the low GC group PCC 6714 for the high GC group 
Table 5. Properties of Synechocystis strains

\begin{tabular}{|c|c|c|c|c|c|c|c|}
\hline \multirow{2}{*}{$\begin{array}{l}\text { Mean DNA } \\
\text { base } \\
\text { composition } \\
\text { (mol \% GC) }\end{array}$} & \multirow[b]{2}{*}{$\begin{array}{l}\text { PCC } \\
\text { no.* }\end{array}$} & \multirow[b]{2}{*}{ Motility } & \multicolumn{3}{|c|}{$\begin{array}{l}\text { Facultative photoheterotroph, } \\
\text { using: }\end{array}$} & \multirow{2}{*}{$\begin{array}{l}\text { Synthesis } \\
\text { of nitro- } \\
\text { genase in } \\
\text { anaero- } \\
\text { biosis }\end{array}$} & \multirow{2}{*}{$\begin{array}{l}\text { Synthesis } \\
\text { of } \\
\text { C-PE } \dagger\end{array}$} \\
\hline & & & Glucose & Sucrose & Glycerol & & \\
\hline \multirow{5}{*}{$35-37$} & 6308 & - & - & - & - & - & - \\
\hline & 6701 & - & - & - & - & - & + \\
\hline & 6711 & + & - & - & - & - & + \\
\hline & 6804 & + & - & - & - & - & - \\
\hline & 6808 & + & - & - & - & - & + \\
\hline \multirow[t]{12}{*}{$\uparrow$} & $6702)$ & - & + & - & - & - & - \\
\hline & 6714 & - & + & - & - & - & - \\
\hline & 6803 & + & + & - & - & - & - \\
\hline & 6805 & - & + & - & - & - & - \\
\hline & 6806 & - & + & - & - & - & - \\
\hline & 6905 & + & + & - & - & - & - \\
\hline & 7201) & + & + & - & - & - & - \\
\hline & 6902 & + & - & - & - & - & - \\
\hline & 6906 & - & $(+)$ & - & + & - & - \\
\hline & 7005 & - & - & - & - & - & - \\
\hline & 7008 & - & - & - & - & - & - \\
\hline & 7509 & - & + & + & - & ND & - \\
\hline & $\begin{array}{l}\text { ND, Not } \\
* \text { Brack } \\
+ \text { C-PE } \\
\text { \$ Requ } \\
\S \text { s, Vit }\end{array}$ & $\begin{array}{l}\text { ent fo } \\
B_{12}\end{array}$ & $\begin{array}{l}\text { +), we } \\
\text { e proba }\end{array}$ & $\begin{array}{l}\text { k growth. } \\
\text { bly indepe } \\
\text { ntrations }\end{array}$ & ndent isol & tes of $t$ & $\begin{array}{l}\text { ame specie } \\
{ }^{2+} \text {. } \\
\text { uirement. }\end{array}$ \\
\hline
\end{tabular}

Vitamin
$B_{12}$
require-
ment§

\section{Genus Gloeocapsa Kützing 1843}

The four strains that conform to the definition of this genus are recent isolates and none has been described previously. Two of them (PCC 7428 and 73106) are shown in Figs 7 and 8. The strain histories are as follows:

ATCC 27928 PCC 73106. R. Rippka, sphagnum bog, Switzerland, 1972.

ATCC 29159 PCC 7428. $\stackrel{\text { I }}{\leftarrow}$ A. Neilson, moderate hot spring, Amparai District, Maha Oya, Ceylon, 1973.

ATCC 29113 PCC 7501. J. B. Waterbury, rock scraping, Pont Neuf, Paris, France, 1975. ATCC 29115 PCC 7512. $\stackrel{\mathrm{I}}{\leftarrow}$ J. B. Waterbury, rock scraping, Pont Neuf, Paris, France, 1975.

The range of DNA base composition is narrow (40 to $46 \mathrm{~mol} \% \mathrm{GC}$; Herdman et al., 1979) and similar to the ranges both for Gloeothece ( 40 to $43 \mathrm{~mol} \% \mathrm{GC}$ ) and for the high GC cluster of Synechocystis (42 to $48 \mathrm{~mol} \% \mathrm{GC}$ ). The four strains are phenotypically distinguishable by the characters shown in Table 6.

\section{Reference strain: PCC 73106}

Genus Chamaesiphon Braun \& Grunow 1865 emend. Geitler 1925

The two strains of Chamaesiphon (Figs 9 and 10) have both been in culture for many years, but were wrongly identified in earlier publications: PCC 6605 as Synechococcus sp. (Stanier et al., 1971) and PCC 7430 as Chroococcidiopsis sp. (Komarek \& Hindak, 1975). Their histories are as follows:

ATCC 27169 PCC 6605 (Stanier et al., 1971). M. M. Allen, stream water, Berkeley, California, U.S.A., 1966. 
Table 6. Properties of Gloeocapsa strains

$\begin{array}{cccccccccccc}\begin{array}{c}\text { Mean DNA } \\ \text { base } \\ \text { composition } \\ \text { (mol \% GC) }\end{array} & \begin{array}{c}\text { PCC } \\ \text { no. }\end{array} & \text { Motility } & \text { Glucose } & \text { Fructose } & \text { Ribose } & \text { Sucrose Glycerol } & \text { Facultative photoheterotroph, using: } & \begin{array}{c}\text { Synthesis of } \\ \text { nitrogenase } \\ \text { in }\end{array} & \begin{array}{c}\text { Synthesis } \\ \text { of }\end{array} \\ \uparrow & 73106 & + & - & - & - & - & - & - & - & + & - \\ 40-46 & 7428 & - & + & + & + & + & - & - & - & - \\ \downarrow & 7501 & + & + & - & - & - & - & - & - & + \\ \downarrow & 7512 & - & - & - & - & - & - & - & + & -\end{array}$

* C-PE, C-phycoerythrin; X-PE, phycoerythrinoid pigment tentatively designated as being spectroscopically distinct from C-phycoerythrin.
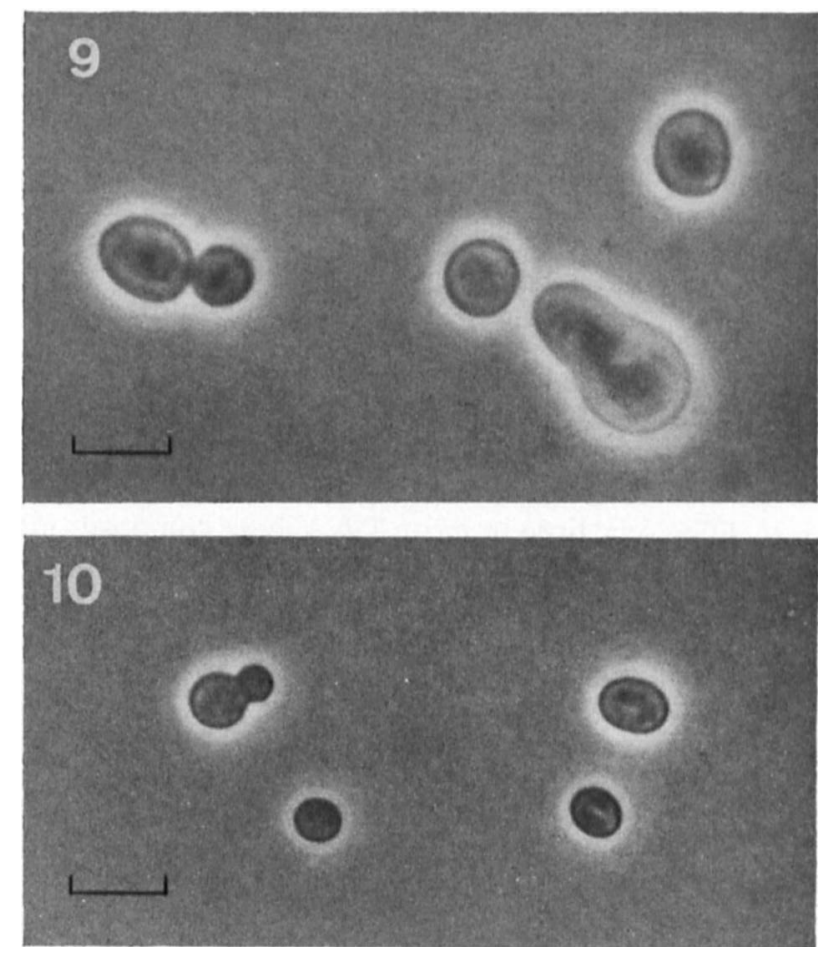

Figs 9 and 10. Chamaesiphon PCC 7430 and PCC 6605, respectively. Both phase contrast; bar markers represent $5 \mu \mathrm{m}$.

ATCC 29397 PCC 7430 (Waterbury \& Stanier, 1977). $\stackrel{\mathrm{x}}{\leftarrow}$ J. Komarek $\leftarrow$ F. Hindak (Chroococcidiopsis sp., strain 1963/133), stream water, Sarka Valley near Prague, Czechoslovakia, 1963 (Komarek \& Hindak, 1975; Komarek, 1972).

Although these two strains are identical in mean DNA base composition ( $47 \mathrm{~mol} \% \mathrm{GC}$; Herdman et al., 1979), they differ phenotypically in many respects and clearly represent two different species (Waterbury \& Stanier, 1977). Strain PCC 6605 has much smaller cells than PCC 7430. It is an obligate autotroph, whereas PCC 7430 can grow photoheterotrophically with glucose, fructose and sucrose. Both strains produce C-phycoerythrin and PCC 6605 exhibits chromatic adaptation (Waterbury \& Stanier, 1977).

Reference strain: PCC 7430 
Table 7. Section II: Unicellular cyanobacteria that reproduce by multiple fission

\begin{tabular}{|c|c|c|}
\hline \multirow[b]{2}{*}{$\begin{array}{l}\text { Reproduction only by } \\
\text { multiple fission }\end{array}$} & \multicolumn{2}{|c|}{$\begin{array}{l}\text { Baeocytes without fibrous outer wall layer } \\
\text { ( Baeocytes with fibrous outer wall layer }\end{array}$} \\
\hline & $\begin{array}{l}\text { Motile baeocytes } \\
\text { Immotile baeocytes }\end{array}$ & $\begin{array}{l}\text { Dermocarpa } \\
\text { Xenococcus }\end{array}$ \\
\hline \multirow{3}{*}{$\begin{array}{l}\text { Reproduction by both } \\
\text { binary fission and } \\
\text { multiple fission }\end{array}$} & $\begin{array}{l}\text { Binary fission leads to pear-shaped structure com- } \\
\text { posed of one or two basal cells and one apical } \\
\text { cell; subsequent multiple fission of the apical } \\
\text { cell yields motile baeocytes } \bigcirc\end{array}$ & Dermocarpella \\
\hline & $\begin{array}{l}\text { Binary fission yields cubical cellular aggregates; } \\
\text { subsequent multiple fission yields: } \\
\text { motile baeocytes } \\
\text { immotile baeocytes }\end{array}$ & $\begin{array}{l}\text { Myxosarcina } \\
\text { Chroococcidiopsis }\end{array}$ \\
\hline & $\begin{array}{l}\text { Binary fission yields irregular cellular aggregates } \\
\text { (pseudofilamentous); subsequent multiple fission } \\
\text { yields motile baeocytes }\end{array}$ & Pleurocapsa group \\
\hline
\end{tabular}

\section{Genera of Section II}

The 32 strains of this section are assigned to five genera, all long recognized by phycologists, and to one provisional assemblage, termed the Pleurocapsa group (Table 7). The choice of generic names and the problem of generic definitions in Section II are discussed by Waterbury \& Stanier (1978). Although diverse in structural and developmental respects, the members of Section II differ very little in mean DNA base composition: the overall range is 38 to $47 \mathrm{~mol} \%$ GC (Herdman et al., 1979). Consequently DNA base composition is not a useful character for distinguishing genera, or (with one exception: see Table 10) for making intrageneric sub-divisions.

\section{Genus Dermocarpa Crouan \& Crouan 1858}

A marine strain, PCC 7301, is carried in two algal culture collections as Dermocarpa violacea, type species of the genus; however, no justification for this specific name has been published. Two freshwater strains, PCC 7437 and 7438, were described on the basis of the study of impure cultures (Komarek \& Hindak, 1975) as Chroococcidiopsis cyanosphaera: subsequent structural and developmental study of the pure strains showed that they were typical members of the genus Dermocarpa (Waterbury \& Stanier, 1978). A representative of this genus is shown in Fig. 11. The histories of the strains are as follows:

ATCC 29367 PCC 7301 (Waterbury \& Stanier, 1978). $\stackrel{\text { P }}{\leftarrow}$ R. A. Lewin, marine aquarium, Scripps Institute of Oceanography, La Jolla, California, U.S.A., 1964. Named as Dermocarpa violacea in CCAP (1416/1) (Culture Collection of Algae and Protozoa: List of Strains, 1971) and UTEX (1635) (Starr, 1971).

ATCC 29368 PCC 7302 (Waterbury \& Stanier, 1978). J. B. Waterbury, sea water tank, Arizona Marine Station, Puerto Penasco, Mexico, 1971.

ATCC 29369 PCC 7303 (Waterbury \& Stanier, 1978). J. B. Waterbury, sea water tank, Arizona Marine Station, Puerto Penasco, Mexico, 1971.

ATCC 29370 PCC 7304 (Waterbury \& Stanier, 1978). J. B. Waterbury, epiphyte on Rhodochorton sp., high intertidal zone, Bodega Marine Laboratory, California, U.S.A., 1970.

ATCC 29371 PCC 7437 (Waterbury \& Stanier, 1978). $\stackrel{\text { I }}{\leftarrow}$ J. Komarek $\leftarrow$ F. Hindak (Chroococcidiopsis cyanosphaera, strain 1965/25), pool, botanical garden, 

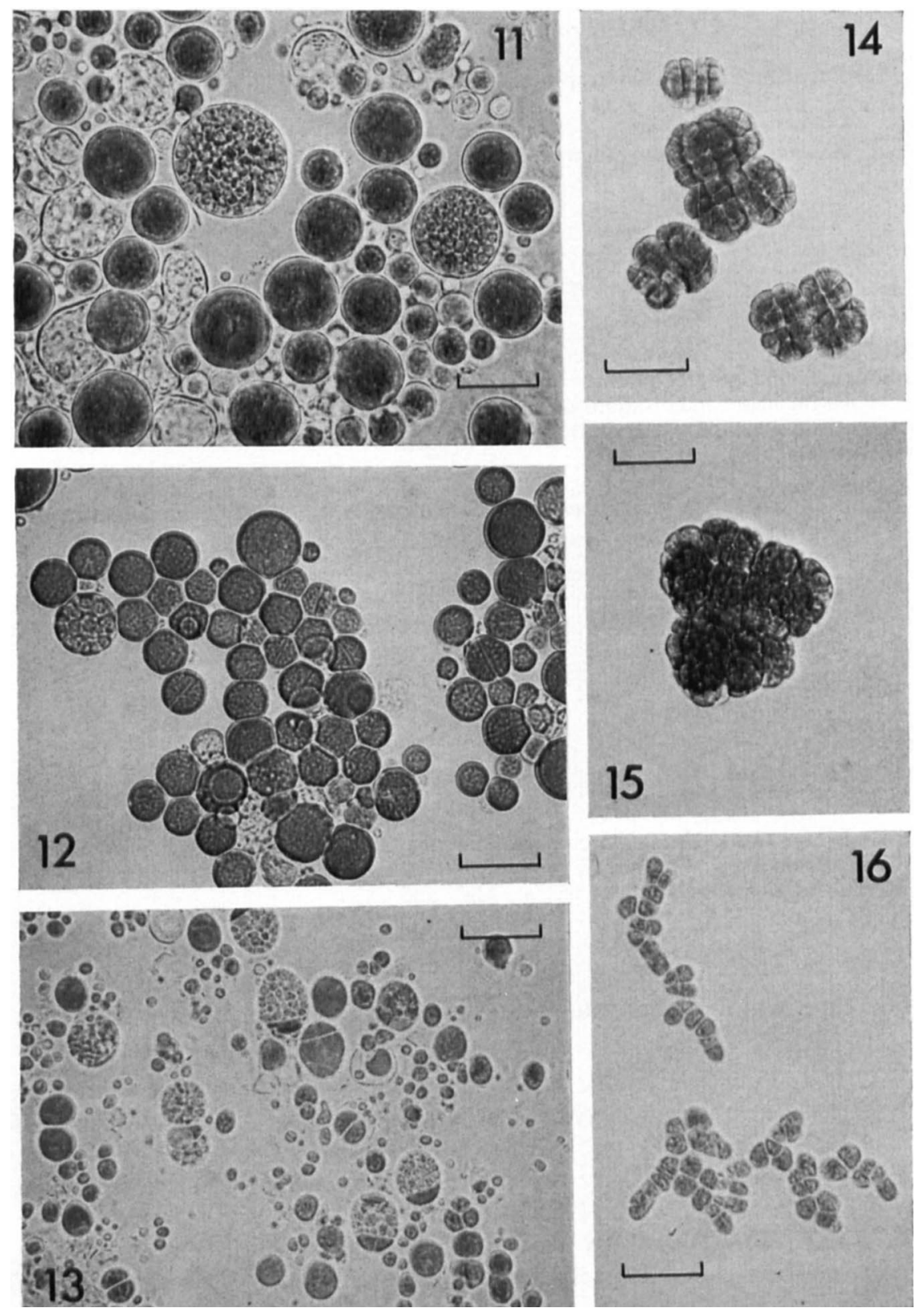

Figs 11 to 16. Representatives of the pleurocapsalean genera. Dermocarpa PCC 7437 (Fig. 11), Xenococcus PCC 7306 (Fig. 12), Dermocarpella PCC 7326 (Fig. 13), Myxosarcina PCC 7312 (Fig. 14), Chroococcidiopsis PCC 7431 (Fig. 15) and Pleurocapsa strain PCC 7319 (Fig. 16). All bright field; bar markers represent $20 \mu \mathrm{m}$.

Havana, Cuba, 1965 (Komarek \& Hindak, 1975; Komarek, 1972; Komarek et al., 1975).

ATCC 29372 PCC 7438 (Waterbury \& Stanier, 1978). $\stackrel{\text { I }}{\leftarrow}$ J. Komarek $\leftarrow$ F. Hindak (Chroococcidiopsis cyanosphaera, strain 1965/26), mineral spring, near Santa Fé, Cuba, 1965 (Komarek \& Hindak, 1975; Komarek, 1972).

Some strain properties are shown in Table 8. 
Table 8. Properties of Dermocarpa strains

Facultative photoheterotroph, Synthesis of using: nitrogenase Synthesis of:*

PCC no. $\overbrace{\text { Glucose }}$ Fructose $\overbrace{\text { Sucrose anaerobiosis }}^{\text {in }} \overbrace{\mathrm{C}-\mathrm{PE}}^{\mathrm{X}-\mathrm{PE}}$ Marinet requirement

$\begin{array}{lllllllll}7301 & + & + & + & + & + & - & + & +^{\circ} \\ 7302 & - & - & - & - & + & - & + & +^{\mathrm{s}} \\ 7303 & - & - & - & + & + & - & + & +^{\mathrm{s}} \\ 7304 & + & - & + & - & - & + & + & - \\ 7437 & + & - & + & - & + & - & - & - \\ 7438 & + & + & - & - & - & + & - & -\end{array}$

* C-PE, C-phycoerythrin; X-PE, phycoerythrinoid pigment tentatively designated as being spectroscopically distinct from C-phycoerythrin.

$\dagger$ Requirement for high concentrations of $\mathrm{Na}^{+}, \mathrm{Mg}^{2+}$ and $\mathrm{Ca}^{2+}$.

$\ddagger \mathrm{o}$, Obligate requirement for vitamin $\mathrm{B}_{12} ; \mathrm{s}$, vitamin $\mathrm{B}_{12}$ stimulates growth markedly, but is not an obligate requirement.

Table 9. Properties of Xenococcus, Dermocarpella and Myxosarcina strains

\begin{tabular}{|c|c|c|c|c|c|c|c|c|}
\hline \multirow[b]{2}{*}{ Genus } & \multirow[b]{2}{*}{ PCC no. } & \multicolumn{3}{|c|}{$\begin{array}{c}\text { Facultative } \\
\text { photoheterotroph, using: }\end{array}$} & \multirow{2}{*}{$\begin{array}{c}\text { Synthesis of } \\
\text { nitrogenase } \\
\text { in } \\
\text { anaerobiosis }\end{array}$} & \multicolumn{2}{|c|}{ Synthesis of:* } & \multirow[b]{2}{*}{ Marine $\dagger$} \\
\hline & & Glucose & Fructose & Sucrose & & C-PE & X-PE & \\
\hline Xenococcus & $\begin{array}{l}7305 \\
7306 \\
7307\end{array}$ & $\begin{array}{l}- \\
- \\
+\end{array}$ & $\begin{array}{l}- \\
- \\
-\end{array}$ & $\begin{array}{l}- \\
- \\
+\end{array}$ & $\begin{array}{l}+ \\
- \\
-\end{array}$ & $\begin{array}{l}- \\
- \\
-\end{array}$ & $\begin{array}{l}+ \\
+ \\
+\end{array}$ & $\begin{array}{l}+ \\
+ \\
+\end{array}$ \\
\hline Dermocarpella & 7326 & + & + & + & - & + & - & + \\
\hline Myxosarcina & $\begin{array}{l}7312 \\
7325\end{array}$ & $\bar{t}$ & - & $\begin{array}{l}+ \\
+\end{array}$ & + & $\bar{t}$ & + & $\begin{array}{l}+ \\
+\end{array}$ \\
\hline
\end{tabular}

* C-PE, C-phycoerythrin; X-PE, phycoerythrinoid pigment tentatively designated as being spectroscopically distinct from C-phycoerythrin.

$\uparrow$ Requirement for high concentrations of $\mathrm{Na}^{+}, \mathrm{Mg}^{2+}$ and $\mathrm{Ca}^{2+}$.

\section{Genus Xenococcus Thuret 1880}

One of the three strains in this genus is shown in Fig. 12. The histories of the strains are as follows:

ATCC 29373 PCC 7305 (Waterbury \& Stanier, 1978). $\stackrel{\text { P }}{\leftarrow}$ R. A. Lewin (Dermocarpa sp.), marine aquarium, Scripps Institute of Oceanography, La Jolla, California, U.S.A., 1971.

ATCC 29374 PCC 7306 (Waterbury \& Stanier, 1978). J. B. Waterbury, rock chip, high intertidal zone, Pillar Point, California, U.S.A., 1970.

ATCC 29375 PCC 7307 (Wäterbury \& Stanier, 1978). J. B. Waterbury, rock chip, high intertidal zone, Horseshoe Cove, Bodega Marine Laboratory, California, U.S.A., 1970.

Some strain properties are shown in Table 9.

Reference strain: PCC 7305

\section{Genus Dermocarpella Lemmermann 1907}

This genus is so far represented by only one strain, illustrated in Fig. 13, which has the following history:

ATCC 29376 PCC 7326 (Waterbury \& Stanier, 1978). J. B. Waterbury, snail shell, intertidal zone, Arizona Marine Station, Puerto Penasco, Mexico, 1971.

Some properties of the strain are summarized in Table 9. 
Genus Myxosarcina Printz 1921

One of the two strains in this genus is shown in Fig. 14. Their histories are as follows:

ATCC 29377 PCC 7312 (Waterbury \& Stanier, 1978). J. B. Waterbury, snail shell, intertidal zone, Arizona Marine Station, Puerto Penasco, Mexico, 1971.

ATCC 29378 PCC 7325 (Waterbury \& Stanier, 1978). J. B. Waterbury, snail shell, intertidal zone, Arizona Marine Station, Puerto Penasco, Mexico, 1971.

Some properties of the strains are shown in Table 9.

\section{Reference strain: PCC 7312}

\section{Genus Chroococcidiopsis Geitler 1933}

A representative of this genus (PCC 7431) is shown in Fig. 15. One strain (PCC 6712) was described by Stanier et al. (1971) as Chlorogloea sp., since the formation of baeocytes was not observed. A second strain (PCC 7203) was received as Myxosarcina chroococcoides, but was transferred to Chroococcidiopsis as a result of the observation that it produces immotile baeocytes (Waterbury \& Stanier, 1978). The strain histories are as follows:

ATCC 27176 PCC 6712 (Stanier et al., 1971; Waterbury \& Stanier, 1978). R. Kunisawa, water sample, reservoir, Marin County, California, U.S.A., 1967. Named as Chlorogloea sp. in CCAP (1411/2) (Culture Collection of Algae and Protozoa: Second Amendments to the 1971 List of Strains, 1973).

ATCC 27900 PCC 7203 (Waterbury \& Stanier, 1978). $\stackrel{\text { I }}{\leftarrow}$ CCAP $\stackrel{\text { I }}{\leftarrow}$ Ernst-Moritz ArndtUniversity, soil sample, near Greifswald, East Germany, 1962 (Komarek, 1972). Named as Myxosarcina chroococcoides in CCAP (1451/1) (Culture Collection of Algae and Protozoa: List of Strains, 1971).

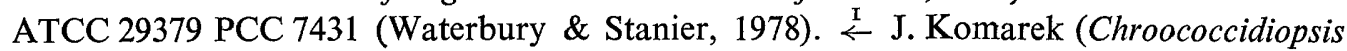
thermalis, strain 1964/48), mineral spring, near San Diego, Cuba, 1964 (Komarek \& Hindak, 1975; Komarek, 1972).

ATCC 29380 PCC 7432 (Waterbury \& Stanier, 1978). $\stackrel{\text { I }}{\leftarrow}$ J. Komarek $\leftarrow$ F. Hindak (Chroococcidiopsis thermalis, strain 1965/21), spring, near Santa Fé, Cuba, 1965 (Komarek \& Hindak, 1975; Komarek, 1972).

ATCC 29381 PCC 7433 (Waterbury \& Stanier, 1978). $\stackrel{\text { I }}{\leftarrow}$ J. Komarek $\leftarrow$ F. Hindak (Chroococcidiopsis thermalis, strain 1966/27), soil, dried pool, Pinar del Rio, Cuba, 1966 (Komarek \& Hindak, 1975; Komarek, 1972).

ATCC 29382 PCC 7434 (Waterbury \& Stanier, 1978). $\stackrel{\text { I }}{\leftarrow}$ J. Komarek $\leftarrow$ F. Hindak (Chroococcidiopsis cubana, strain 1965/19), pool, botanical garden, Havana, Cuba, 1965 (Komarek \& Hindak, 1975; Komarek, 1972).

ATCC 29383 PCC 7436 (Waterbury \& Stanier, 1978). $\stackrel{\text { I }}{\leftarrow}$ J. Komarek $\leftarrow$ F. Hindak (Chroococcidiopsis cubana, strain 1965/108), drainage ditch, Nueva Gerona, Cuba, 1965 (Komarek \& Hindak, 1975).

ATCC 29384 PCC 7439 (Waterbury \& Stanier, 1978). $\stackrel{\text { I }}{\leftarrow}$ J. Komarek $\leftarrow$ F. Hindak (Chroococcidiopsis doonensis, strain 1968/64), sand beach, near Mamaia, Romania, 1968 (Komarek \& Hindak, 1975).

Some properties of Chroococcidiopsis strains are summarized in Table 10. Excluding PCC 6712, and possibly 7434, the strains of this genus are probably independent isolates of one species: they cannot be distinguished by DNA base composition, structure and development, or other major phenetic properties. It should be noted that an earlier study of structure and development conducted with impure cultures (Komarek \& Hindak, 1975) resulted in the assignment of some of these strains to three different species of Chroococcidiopsis (see histories).

Reference strain: PCC 7203 
Table 10. Properties of Chroococcidiopsis strains

\begin{tabular}{|c|c|c|c|c|c|c|c|}
\hline \multirow[b]{2}{*}{ PCC no.* } & \multirow{2}{*}{$\begin{array}{c}\text { Mean DNA } \\
\text { base } \\
\text { composition } \\
\text { (mol } \% \text { GC) }\end{array}$} & \multicolumn{3}{|c|}{$\begin{array}{c}\text { Facultative photoheterotroph, } \\
\text { using: }\end{array}$} & \multirow{2}{*}{$\begin{array}{c}\text { Synthesis of } \\
\text { nitrogenase } \\
\text { in } \\
\text { anaerobiosis }\end{array}$} & \multicolumn{2}{|c|}{ Synthesis of: $†$} \\
\hline & & Glucose & Fructose & Sucrose & & $\mathrm{X}-\mathrm{PE}$ & PEC \\
\hline 6712 & 40 & + & + & + & + & + & - \\
\hline 7203$)$ & 46 & + & + & + & + & - & + \\
\hline 7431 & 46 & + & + & + & + & - & + \\
\hline 7432 & 46 & + & + & + & + & - & + \\
\hline 7433 & 46 & + & + & + & + & - & + \\
\hline 7436 & 46 & + & + & + & + & - & + \\
\hline 7439 & 46 & + & + & + & + & - & + \\
\hline 7434 & 46 & - & + & - & + & - & - \\
\hline
\end{tabular}

$*$ The bracketed strains are probably independent isolates of the same species.

$\dagger \mathrm{X}-\mathrm{PE}$, Phycoerythrinoid pigment tentatively designated as being spectroscopically distinct from C-phycoerythrin; PEC, phycoerythrocyanin.

\section{The Pleurocapsa group}

This is a provisional designation and is given to a group of strains that are diverse and variable in development; an example (PCC 7319) is shown in Fig. 16. This group of strains corresponds broadly to the organisms included by phycologists in the genera Pleurocapsa (Thuret) Hauck 1885, Hyella Bornet \& Flahaut 1888, Hydrococcus Kützing 1833, Onkonema Geitler 1933 and Tryponema Ercegovic 1929 (family Pleurocapsaceae or Hyellaceae). The histories of the strains are as follows:

ATCC 29385 PCC 7310 (Waterbury \& Stanier, 1978). J. B. Waterbury, snail shell, intertidal zone, Arizona Marine Station, Puerto Penasco, Mexico, 1971.

ATCC 29386 PCC 7314 (Waterbury \& Stanier, 1978). Isolator and source as for ATCC 29385.

ATCC 29387 PCC 7317 (Waterbury \& Stanier, 1978). Isolator and source as for ATCC 29385.

ATCC 29388 PCC 7319 (Waterbury \& Stanier, 1978). Isolator and source as for ATCC 29385.

ATCC 29389 PCC 7320 (Waterbury \& Stanier, 1978). Isolator and source as for ATCC 29385.

ATCC 29390 PCC 7321 (Waterbury \& Stanier, 1978). Isolator and source as for ATCC 29385.

ATCC 29391 PCC 7322 (Waterbury \& Stanier, 1978). Isolator and source as for ATCC 29385.

ATCC 29392 PCC 7324 (Waterbury \& Stanier, 1978). Isolator and source as for ATCC 29385.

ATCC 29393 PCC 7327 (Waterbury \& Stanier, 1978). $\stackrel{\text { }}{\leftarrow}$ R. Castenholz (Pleurocapsa minor OH-69-pm), Hunter's Spring, Oregon, U.S.A., 1969 (Castenholz, 1970).

ATCC 29394 PCC 7440 (Waterbury \& Stanier, 1978). J. B. Waterbury, rock chip, high intertidal zone, Deauville, Normandy, France, 1974.

ATCC 29395 PCC 7506 (Waterbury \& Stanier, 1978). J. B. Waterbury, rock chip, collected by T. Le Campion-Alsumard, Marseille, France, 1964.

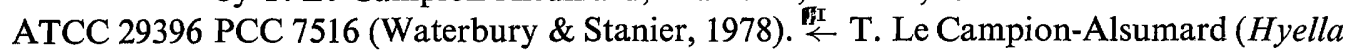
caespitosa), rock chip, station B, l'Ile Riou, Marseille, France, 1974 (Le Campion-Alsumard, 1972).

Some strain properties of the Pleurocapsa group are shown in Table 11. No reference strains are proposed. 
Table 11. Properties of strains of the Pleurocapsa group

\begin{tabular}{|c|c|c|c|c|c|c|c|c|c|}
\hline \multirow[b]{2}{*}{ PCC no. } & \multicolumn{3}{|c|}{$\begin{array}{c}\text { Facultative } \\
\text { photoheterotroph, using: }\end{array}$} & \multirow{2}{*}{$\begin{array}{l}\text { Synthesis of } \\
\text { nitrogenase } \\
\text { in } \\
\text { anaerobiosis }\end{array}$} & \multicolumn{2}{|c|}{ Synthesis of:* } & \multirow[b]{2}{*}{ Thermophil } & \multirow[b]{2}{*}{ Marinet: } & \multirow{2}{*}{$\begin{array}{c}\text { Vitamin } \\
\mathbf{B}_{12} \\
\text { require- } \\
\text { ment§ }\end{array}$} \\
\hline & Glucose & Fructose & Sucrose & & C-PE & $X-P E$ & & & \\
\hline 7310 & - & - & + & - & + & - & - & + & $+s$ \\
\hline 7314 & - & + & + & + & + & - & - & + & - \\
\hline 7317 & + & - & - & - & + & - & - & + & +0 \\
\hline 7319 & - & + & + & - & - & + & - & + & - \\
\hline 7320 & + & + & + & + & - & + & - & + & - \\
\hline 7321 & - & - & + & + & - & + & - & - & - \\
\hline 7322 & + & + & + & + & + & - & - & + & - \\
\hline 7324 & - & - & - & + & + & - & - & + & - \\
\hline 7327 & - & - & + & + & + & - & + & - & - \\
\hline 7440 & - & - & - & - & + & - & - & + & - \\
\hline 7506 & + & - & - & - & - & $N D$ & - & + & - \\
\hline 7516 & - & - & + & + & + & - & - & + & - \\
\hline
\end{tabular}

ND, Not determined.

* C-PE, C-phycoerythrin; X-PE, phycoerythrinoid pigment tentatively designated as being spectroscopically distinct from C-phycoerythrin.

$\dagger$ Maximum growth temperature, $55^{\circ} \mathrm{C}$.

+ Requirement for high concentrations of $\mathrm{Na}^{+}, \mathrm{Mg}^{2+}$ and $\mathrm{Ca}^{2+}$.

$\S$, Obligate requirement for vitamin $\mathrm{B}_{12} ; \mathrm{s}$, vitamin $\mathbf{B}_{12}$ stimulates growth, but is not an obligate requirement.

\section{Genera of Section III}

Of the 44 non-heterocystous, filamentous strains placed in this section, only 19 could be given definite generic assignments; the remainder are included in a provisional group (Table 12, Diagram 1). Many genera have been proposed for members of this large cyanobacterial assemblage, and phycologists are far from agreed about its generic sub-division. Geitler (1932) recognized 25 genera, reduced in a more recent treatment to 11 (Bourrelly, 1970).

Sheath formation has traditionally had a prominent place in the classification of these cyanobacteria, some genera being defined exclusively by properties such as the consistency of sheath material (Lyngbya Agardh 1824, Phormidium Kützing 1843); false branching, a consequence of the consistency of the sheath, (Plectonema Thuret 1875); and special arrangements of trichomes within a common sheath (Microcoleus Desmazières 1823, Schizothrix Kützing 1843). Consequently characters expressed by the structure of the trichome itself have served only to define genera that produce little or no sheath material, such as Spirulina Turpin 1827, Oscillatoria Vaucher 1803 and Pseudanabaena Lauterborn 1915.

Although many strains of Section III can form sheaths, characters connected with sheath formation have for the most part proved determinatively unsatisfactory for the generic identification of cultures. Only in strain PCC 7419 is the trichome regularly surrounded by a firm sheath under all growth conditions; this strain might accordingly be assigned to Lyngbya on the basis of its sheath structure. In other strains that produce sheaths, this character is much influenced by environmental parameters: cultivation in liquid or on solid media, presence or absence of a utilizable sugar, and age of cultures at the time of examination. In several strains received as Plectonema spp., false branching was so rare as to be virtually undetectable under conditions that supported abundant and apparently normal growth. Three strains received as Microcoleus spp. never showed in culture the arrangement of trichomes surrounded by a common sheath nominally characteristic for this genus. We concluded, therefore, that sheath-associated properties are too unreliable to permit generic identifications for strains that belong to Section III.

On the other hand, certain strains of Section III can be readily identified in culture as members of three form genera that produce motile trichomes not surrounded by wellmarked sheaths; each genus is traditionally defined by the properties of the trichomes. 
Table 12. Section III: Filamentous non-heterocystous cyanobacteria that divide in only one plane

\begin{tabular}{|c|c|c|}
\hline $\begin{array}{c}\text { Trichome } \\
\text { helical }\end{array}$ & $\begin{array}{l}\text { Cells composing trichome are iso- } \\
\text { diametric, cylindrical or } \\
\text { disc-shaped; little or no } \\
\text { constriction between adjacent } \\
\text { cells; reproduction by trans- } \\
\text { cellular trichome breakage (?) }\end{array}$ & $\begin{array}{l}\text { Trichome motile, either not ensheathed } \\
\text { or thinly sheathed } \\
\text { Spirulina }\end{array}$ \\
\hline \multirow{4}{*}{$\begin{array}{c}\text { Trichome } \\
\text { straight }\end{array}$} & \multirow{2}{*}{$\begin{array}{l}\text { Cells composing trichome are } \\
\text { disc-shaped and not separated by } \\
\text { deep constrictions; reproduction } \\
\text { by transcellular trichome } \\
\text { breakage }\end{array}$} & $\begin{array}{l}\text { Trichome motile, either not ensheathed } \\
\text { or thinly sheathed } \\
\text { Oscillatoria }\end{array}$ \\
\hline & & $\begin{array}{l}\text { Trichome immotile, enclosed by heavy } \\
\text { sheath; motility restricted to sheathless } \\
\text { or thinly sheathed hormogonia } \\
\text { LPP group A }\end{array}$ \\
\hline & \multirow{2}{*}{$\begin{array}{l}\text { Cells composing trichome are iso- } \\
\text { diametric or cylindrical; variable } \\
\text { degree of constriction between } \\
\text { adjacent cells; reproduction by } \\
\text { transcellular or intercellular } \\
\text { trichome breakage }\end{array}$} & $\begin{array}{l}\text { Trichome motile, not ensheathed; cells } \\
\text { contain polar gas vacuoles and are } \\
\text { separated by deep constrictions } \\
\qquad \text { Pseudanabaena }\end{array}$ \\
\hline & & $\begin{array}{l}\text { Not as above; with or without sheath, } \\
\text { motile or immotile } \\
\text { LPP group B }\end{array}$ \\
\hline
\end{tabular}

The trichome of Oscillatoria Vaucher 1803 is straight and composed of disc-shaped cells between which there is little if any constriction. The latter implies that the outer membrane layer participates little in the formation of the transverse walls (Lamont, 1969). Consequently, the trichome does not fragment very easily and often attains a considerable length $(>1 \mathrm{~cm})$. Reproduction occurs only by sacrificial (transcellular) trichome breakage, a process well described by Lamont (1969). The straight trichome of Pseudanabaena Lauterborn 1915 differs from that of Oscillatoria in several respects: the cells are cylindrical, they are separated by deep constrictions and they contain gas vacuoles, revealed by microscopic examination under phase contrast illumination as a light refractile granule at each cell pole (Figs 22 to 24). Reproduction occurs readily by intercellular trichome breakage, and the trichomes of many strains are very short ( 2 to 8 cells). Gas vacuolated species of Oscillatoria and Spirulina do not display the polar location of the gas vacuoles characteristic of Pseudanabaena.

It should be emphasized that the definitions of Pseudanabaena and Oscillatoria presented above are considerably more restrictive than those of many phycologists, being based on the described properties of the respective type species, Pseudanabaena catenata Lauterborn 1915 and Oscillatoria princeps Vaucher 1803.

The trichome of Spirulina Turpin 1827 is also composed of cells between which there is little constriction, and reproduction probably also occurs by transcellular fragmentation. In contrast to Oscillatoria, the trichome of Spirulina is helical, and its cells may be either discshaped, isodiametric or cylindrical. Bourrelly (1970) combines Oscillatoria and Spirulina; however, the helical shape of the trichome of Spirulina is a stable and constant property in culture.

The abandonment of genera defined by sheath-associated characters, as well as the relatively restrictive definitions of the three genera recognized, leaves many strains in Section III without clear-cut generic assignments. They are here provisionally placed in the 


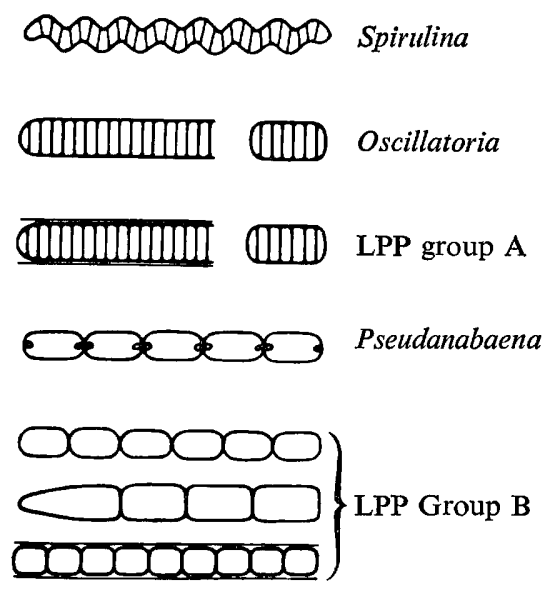

Diagram 1. Schematic presentation of the genera assigned to Section III. Thin lines surrounding trichomes designate sheath material. Polar bodies (Pseudanabaena) represent gas vacuoles.

LPP group, so called because many of the strains included fall within the broad confines of the genera Lyngbya, Phormidium and Plectonema.

\section{Genus Spirulina Turpin 1827}

Only two strains, with markedly different properties, belong to this genus (see Figs 17, 18). Their histories are as follows:

ATCC 29542 PCC 6313 (Kenyon et al., 1972). M. M. Allen, brackish water, Berkeley, California, U.S.A., 1963.

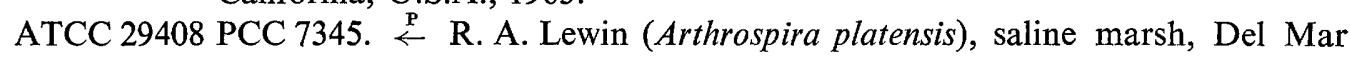
Slough, California, U.S.A., 1969.

Strain PCC 6313, briefly described by Kenyon et al. (1972), forms thin ( $2 \mu \mathrm{m})$ trichomes without gas vacuoles; although isolated from brackish water, it is not a marine strain. Strain PCC 7345 forms wide $(16 \mu \mathrm{m})$, more loosely coiled trichomes, which contain abundant gas vacuoles; it is a true marine strain. Both strains are obligate autotrophs, unable to synthesize nitrogenase anaerobically. Mean DNA base compositions are 44 and $54 \mathrm{~mol} \%$ GC for PCC 7345 and 6313, respectively (Herdman et al., 1979).

Strain PCC 7345, received as Arthrospira platensis, has the relatively thick trichome, containing cross-walls readily evident by light microscopy, that defines this form genus. However, the traditional generic distinction between Arthrospira Stizenberger 1852 and Spirulina Turpin 1827 appears trivial and is not recognized by Geitler (1932). The substantial difference in mean DNA base composition between strains PCC 6313 and 7345 nevertheless suggests that more solid genetic grounds for recognizing these two genera may eventually be found.

Reference strain: PCC 6313

\section{Genus Oscillatoria Vaucher 1803}

Nine strains are included in this genus. Three representatives are illustrated in Figs 19 to 21 . The histories of the strains are as follows:

ATCC 27930 PCC 6304 (Kenyon et al., 1972). $\stackrel{\text { P }}{\leftarrow}$ M. B. Allen, source unknown. Named as Microcoleus vaginatus in SAUG (1449/3) (Koch, 1964).

ATCC 29215 PCC 6401 (Kenyon et al., 1972). M. M. Allen, marine mud, California, U.S.A., 1964. 

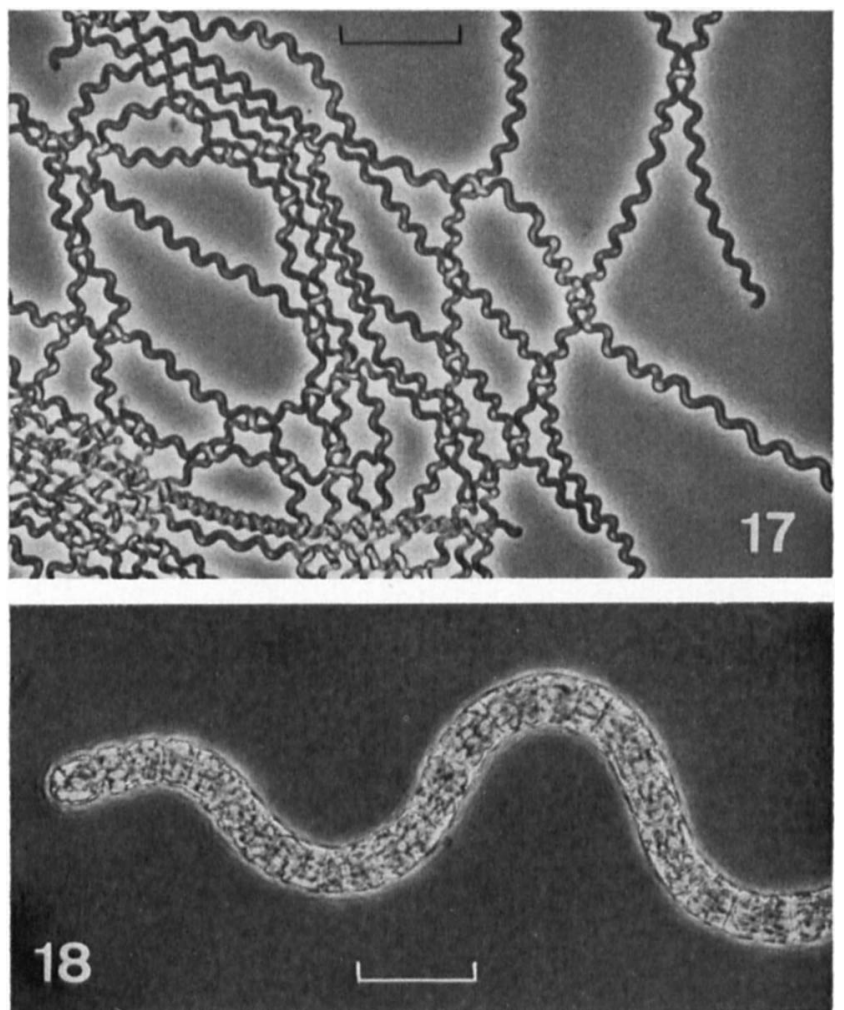

Figs 17 and 18. Spirulina PCC 6313 and PCC 7345, respectively. Both phase contrast; bar markers represent $20 \mu \mathrm{m}$.

ATCC $_{\llcorner} 27906$ PCC 6407 (Kenyon et al., 1972). M. M. Allen, fresh water, California, U.S.A., 1964.

ATCC 29205 PCC 6412 (Kenyon et al., 1972). M. M. Allen, fresh water, California, U.S.A., 1964. Named as Lyngbya sp. in UTEX (1546) (Starr, 1966).

ATCC 29081 PCC 6506 (Kenyon et al., 1972). $\stackrel{\mathrm{P}}{\leftarrow}$ E. G. Pringsheim, source unknown; does not correspond to description by isolator (Pringsheim, 1966). Named as Lyngbya kuetzingii in UTEX (1547) (Starr, 1966).

ATCC 27935 PCC 6602 (Kenyon et al., 1972). M. M. Allen, fresh water, California, U.S.A., 1966.

ATCC 29134 PCC 7112. A. Neilson, soil, orchid house, San Francisco, U.S.A., 1970.

ATCC 29135 PCC 7412. $\stackrel{\leftarrow}{\leftarrow}$ A. Neilson, greenhouse water tank, Stockholm, Sweden, 1972.

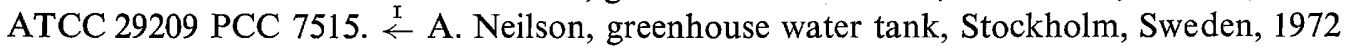

The range of mean DNA base composition is relatively narrow (40 to $50 \mathrm{~mol} \% \mathrm{GC}$; Herdman et al., 1979) and no clear-cut intrageneric sub-groups can be distinguished on this basis. As shown in Table 13, the strains fall into three sub-groups distinguished by the width of the trichome. In the sub-group with the narrowest trichomes (4 to $5 \mu \mathrm{m})$, two clusters of strains appear to be independent isolates of a single species, distinguished by differences with respect to facultative heterotrophy and the capacity to synthesize nitrogenase anaerobically.

Reference strain: PCC 7515 

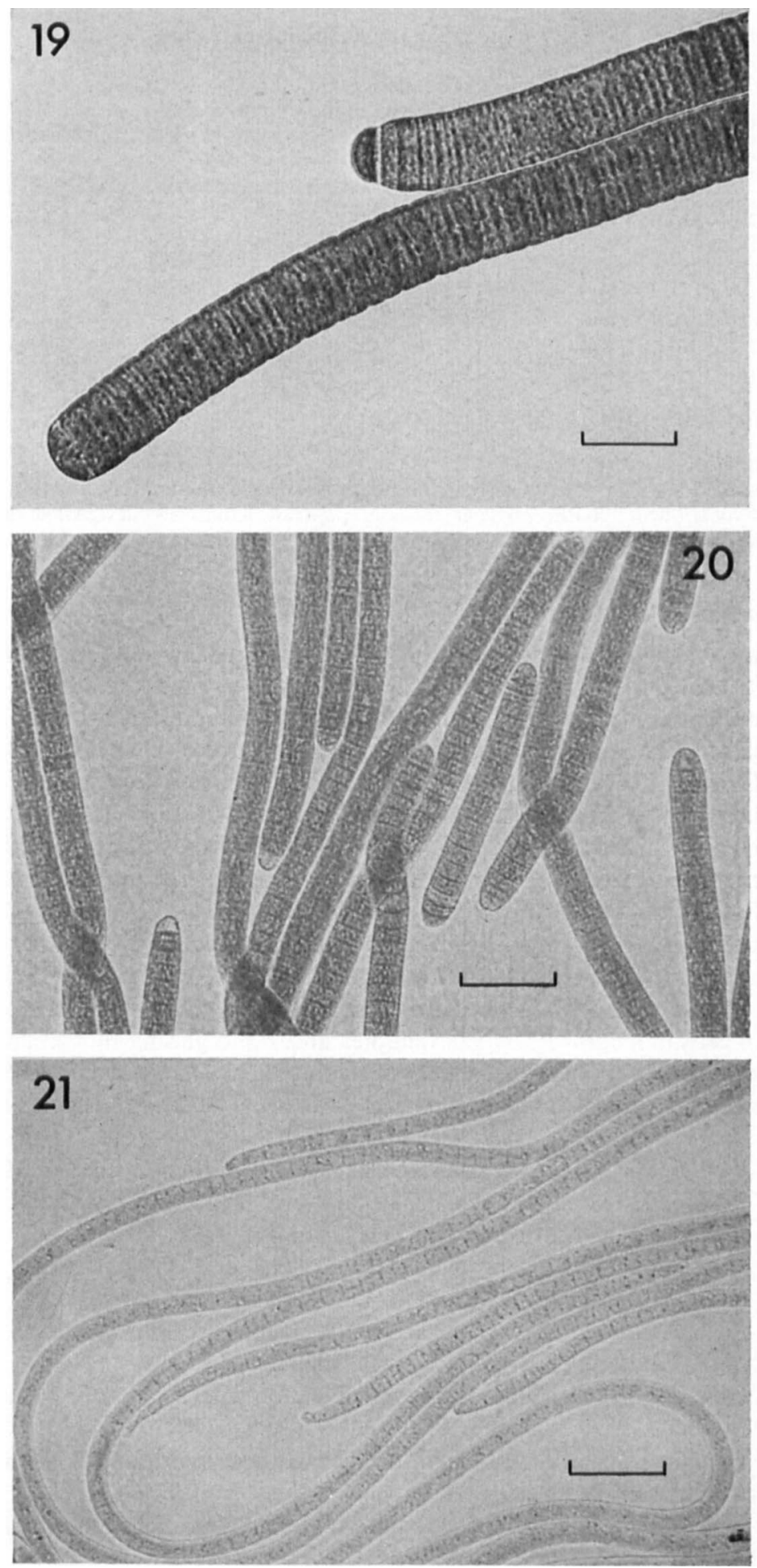

Figs 19 to 21. Oscillatoria PCC 7515, PCC 7112 and PCC 6506, respectively. All bright field; bar markers represent $20 \mu \mathrm{m}$. 
Table 13. Properties of Oscillatoria strains

\begin{tabular}{|c|c|c|c|c|c|c|}
\hline \multirow[b]{2}{*}{ PCC no.* } & \multirow{2}{*}{$\begin{array}{l}\text { Cell width } \\
\qquad(\mu \mathrm{m})\end{array}$} & \multicolumn{2}{|c|}{$\begin{array}{c}\text { Facultative } \\
\text { photoheterotroph, } \\
\text { using: }\end{array}$} & \multirow{2}{*}{$\begin{array}{l}\text { Synthesis of } \\
\text { nitrogenase } \\
\text { in } \\
\text { anaerobiosis }\end{array}$} & \multicolumn{2}{|c|}{ Synthesis of $: \uparrow$} \\
\hline & & Glucose & Fructose & & C-PE & $\mathrm{X}-\mathrm{PE}$ \\
\hline 6304) & $4-5$ & - & - & - & - & - \\
\hline 6401$\}$ & $4-5$ & - & - & - & - & - \\
\hline 7412 & $4-5$ & - & - & - & - & - \\
\hline 6407) & $4-5$ & $(+)$ & - & + & - & - \\
\hline 6412 & $4-5$ & $(+)$ & $(+)$ & + & - & - \\
\hline 6506 & $4-5$ & $(+)$ & - & + & - & - \\
\hline 6602 & $4-5$ & + & + & + & + & - \\
\hline 7112 & $7-8$ & - & - & - & + & - \\
\hline 7515 & $15-16$ & + & + & + & - & + \\
\hline
\end{tabular}

$(+)$, Weak growth.

* Strains bracketed together are probably independent isolates of the same species.

$\uparrow$ C-PE, C-phycoerythrin; X-PE, phycoerythrinoid pigment tentatively designated as being spectroscopically distinct from C-phycoerythrin.

\section{Genus Pseudanabaena Lauterborn 1915}

These cyanobacteria are found in widely diverse aquatic habitats including hot springs (Anagnostidis, 1961), the sulphide-rich anaerobic layer of ponds (Lauterborn, 1915) and marine environments. Nevertheless, some phycologists have long expressed doubts about the validity of the genus, since the trichomes resemble those of an Anabaena sp. without heterocysts (Geitler, 1932). Bourrelly (1970) recently reported that, exceptionally, Pseudanabaena spp. may form heterocysts and considered the boundary between this genus and Anabaena to be imprecise. However, Pringsheim (1968) had shown earlier that two strains of Pseudanabaena were incapable of fixing nitrogen aerobically or of forming heterocysts under a wide variety of growth conditions. We have confirmed Pringsheim's observations for many additional strains. The boundary vis-à-vis Anabaena is, accordingly, clear-cut.

Three of the eight strains assigned to this genus (PCC 6802, 6901 and 6903) were originally described by Stanier et al. (1971) as Synechococcus spp., since all form short trichomes, typically 2 to 6 cells in length. Polar gas vacuoles and rapid gliding movement are the principal properties that distinguish short-trichome strains of Pseudanabaena from Synechococcus. Three Pseudanabaena strains are shown in Figs 22 to 24. The strain histories are as follows:

ATCC 29118 PCC 6406. $\stackrel{\text { I }}{\leftarrow}$ M. M. Allen, fresh water, California, U.S.A., 1964.

ATCC 27183 PCC 6802 (Stanier et al., 1971). A. Neilson (Synechococcus sp.), pond water, University of California, Berkeley, U.S.A., 1968.

ATCC 27263 PCC 6901 (Stanier et al., 1971). A. Neilson (Synechococcus sp.), shallow stream, Tres Pinos, California, U.S.A., 1969.

ATCC 27190 PCC 6903 (Stanier et al., 1971). A. Neilson (Synechococcus sp.), brackish pool, Coos Bay, Oregon, U.S.A., 1969.

ATCC 29137 PCC 7367. J. B. Waterbury, snail shell, intertidal zone, Puerto Penasco, Mexico, 1971.

ATCC 29207 PCC 7402. $\stackrel{\text { I }}{\leftarrow}$ J. A. Houghton, pond heavily polluted with pig manure, Ireland, 1972.

ATCC 29210 PCC 7403. R. Rippka, sphagnum bog, near Kastanienbaum, Vierwaldstättersee, Switzerland, 1972.

ATCC 29536 PCC 7429. R. Rippka, sphagnum bog, near Kastanienbaum, Vierwaldstättersee, Switzerland, 1972.

The range of mean DNA base composition is 44 to $52 \mathrm{~mol} \%$ GC (Stanier et al., 1971; 

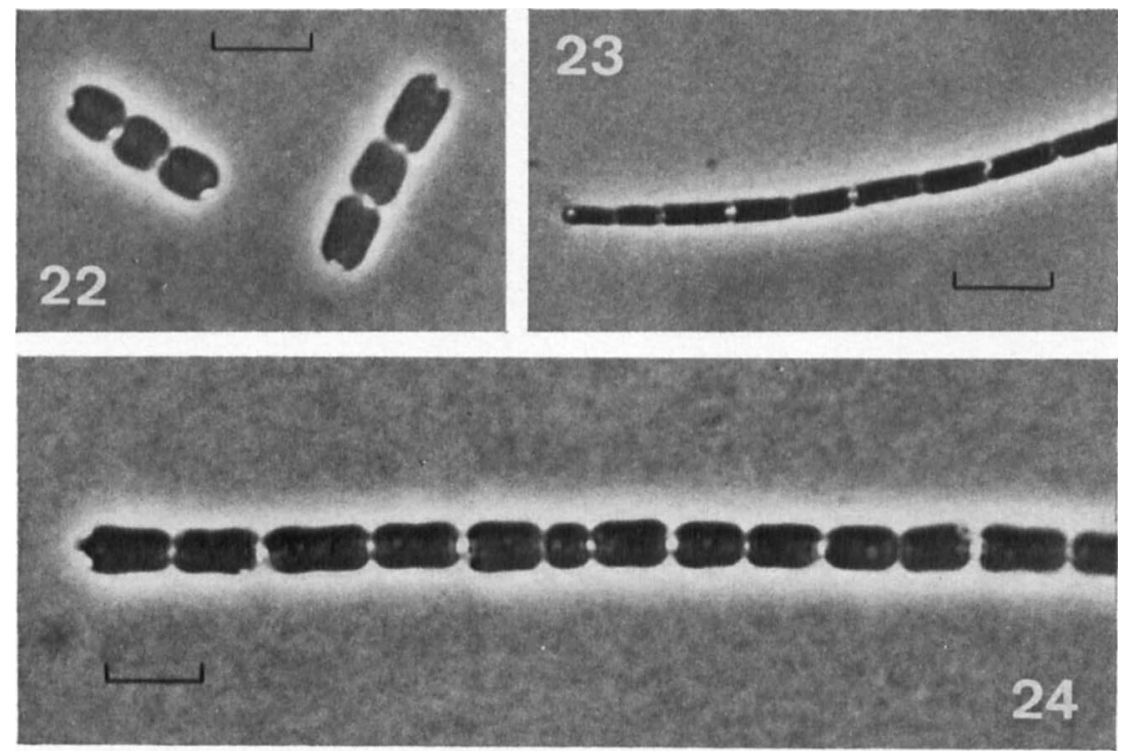

Figs 22 to 24. Pseudanabaena PCC 7402, PCC 6406 and PCC 7429, respectively. All phase contrast; bar markers represent $5 \mu \mathrm{m}$.

Table 14. Properties of Pseudanabaena strains

\begin{tabular}{cccccccc} 
No. of & $\begin{array}{c}\text { Noll width } \\
\text { cells in a } \\
\text { trichome }\end{array}$ & $\begin{array}{c}\text { Cell } \begin{array}{c}\text { Synthesis of } \\
\text { nitrogenase } \\
\text { in }\end{array} \\
\text { PCC no. }\end{array}$ & \multicolumn{2}{c}{ Synthesis of:* } & & \\
6802 & $1-3$ & $2 \cdot 0-2 \cdot 5$ & + & + & - & - & - \\
6901 & $3-6$ & $1 \cdot 3-1 \cdot 8$ & - & - & - & + & - \\
6903 & $3-6$ & $2 \cdot 5-3 \cdot 0$ & - & - & - & + & - \\
7402 & $3-6$ & $2 \cdot 0-2 \cdot 5$ & - & - & - & + & - \\
7403 & $3-6$ & $1 \cdot 8-2 \cdot 3$ & + & - & - & - & - \\
7367 & $4-10$ & $1 \cdot 3-1 \cdot 8$ & - & + & - & + & + \\
6406 & $>10$ & $0 \cdot 8-1 \cdot 3$ & + & - & + & + & - \\
7429 & $>10$ & $2 \cdot 0-2 \cdot 5$ & - & - & - & + & -
\end{tabular}

All strains are obligate photoautotrophs.

* C-PE, C-phycoerythrin; PEC, phycoerythrocyanin.

$\dagger-$, Loss of motility on repeated subculturing in liquid medium.

$\$$ Requirement for high concentrations of $\mathrm{Na}^{+}, \mathrm{Mg}^{2+}$ and $\mathrm{Ca}^{2+}$.

Herdman et al., 1979) and no clear-cut intrageneric separations can be made on this basis. All strains are obligate photoautotrophs. Other properties are shown in Table 14.

\section{Reference strain: PCC 7429}

\section{The LPP group}

Some representatives of the 25 strains assigned to this provisional assemblage are shown in Figs 25 to 32. The histories of the strains are as follows:

ATCC 27894 PCC 6306 (Kenyon et al., 1972). $\stackrel{\text { P }}{\leftarrow}$ M. B. Allen $\stackrel{\text { P }}{\leftarrow}$ M. Dyar (Plectonema notatum), source unknown (Allen, 1952). Named as Plectonema boryanum in UTEX (581) (Starr, 1964) and (1542) (Starr, 1966) and in CCAP (1463/1) (Culture Collection of Algae and Protozoa: List of Strains, 1971).

ATCC 27902 PCC 6402 (Kenyon et al., 1972). M. M. Allen, pond water, California, U.S.A., 1964. Named as Plectonema sp. in UTEX (1541) (Starr, 1966). 

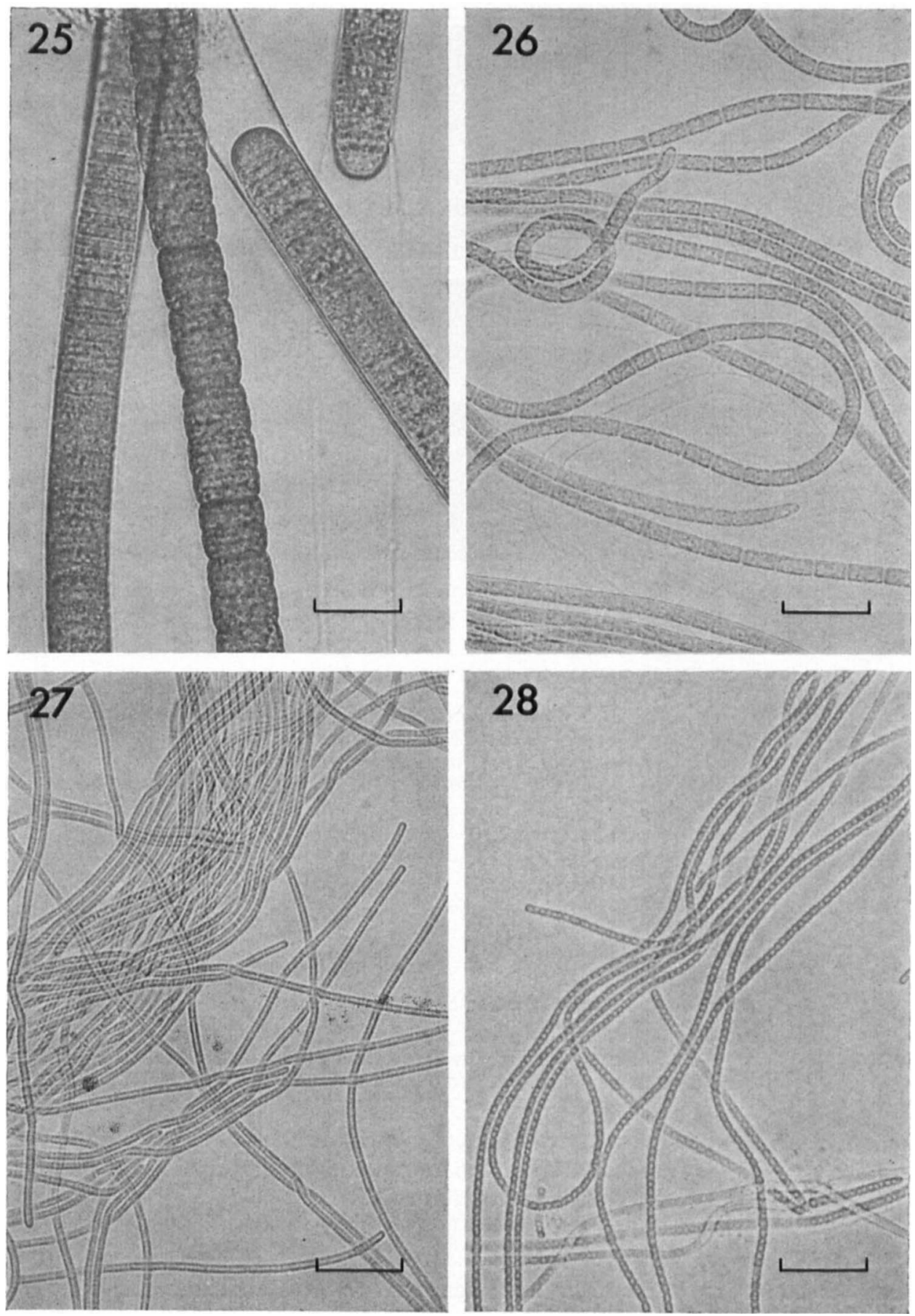

Figs 25 to 28. Representatives of the LPP group. Strain PCC 7419 (Fig. 25), strain PCC 7113 (Fig. 26), strain PCC 7105 (Fig. 27) and strain PCC 7505 (Fig. 28). All bright field; bar markers represent $20 \mu \mathrm{m}$. 

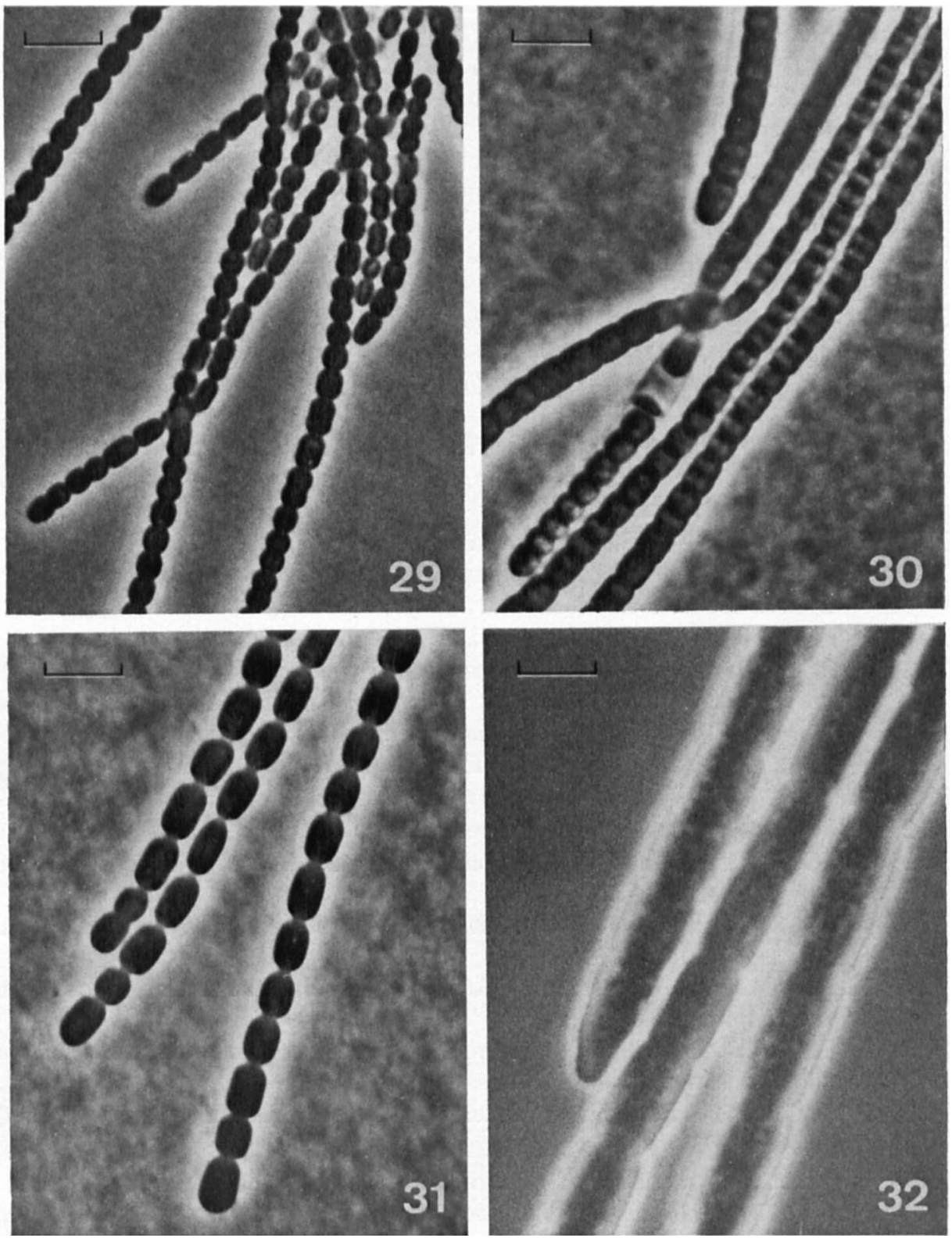

Figs 29 to 32. Representatives of the LPP group at a higher magnification to illustrate cell shape. Strain PCC 7376 (Fig. 29), strain PCC 7505 (Fig. 30), strain PCC 7408 (Fig. 31) and strain PCC 7420 (Fig. 32). All phase contrast; bar markers represent $5 \mu \mathrm{m}$.

ATCC 29119 PCC 6409 (Kenyon et al., 1972). M. M. Allen, pond water, California, U.S.A., 1964. Named as Phormidium sp. in UTEX (1540) (Starr, 1966).

ATCC 27907 PCC 6703 (Kenyon et al., 1972). $\stackrel{\text { I }}{\leftarrow}$ G. Cohen-Bazire, Lake Washington, U.S.A., 1967.

ATCC 27913 PCC 7004 (Kenyon et al., 1972). $\stackrel{\text { P }}{\leftarrow}$ C. Van Baalen (Schizothrix calcicola MAN), mangrove root, Lydia Ann Channel, Port Aransas, Texas, U.S.A., 1962.

ATCC 29117 PCC 7104 (Kenyon et al., 1972). $\stackrel{\text { P }}{\leftarrow}$ C. Van Baalen (Lyngbya lagerheimii 
MONT), rock at shoreline, Montauk Point, Long Island, New York, U.S.A., 1960 (Van Baalen, 1962).

ATCC 29120 PCC 7105. $\stackrel{\text { P }}{\leftarrow}$ C. Van Baalen (Oscillatoria williamsii MEV) $\stackrel{\text { }}{\leftarrow}$ J. J. A. McLaughlin, Haskins Laboratories, 1960, source unknown (Van Baalen \& Marler, 1963).

ATCC 29206 PCC 7113. A. Neilson, soil, orchid house, San Francisco, U.S.A., 1971.

ATCC 29121 PCC 7114. A. Neilson, soil, orchid house, San Francisco, U.S.A., 1971.

ATCC 29122 PCC 7123. A Neilson, soil, orchid house, San Francisco, U.S.A., 1971.

ATCC 29123 PCC 7124. A. Neilson, low salinity brine pond, Port Hedland, Western Australia, 1970.

ATCC 29409 PCC 7375. $\stackrel{\text { P }}{\leftarrow}$ R. A. Lewin (Phormidium ectocarpi) $\stackrel{\text { I }}{\leftarrow}$ P. Strout, plankton, Woods Hole region, Massachusetts, U.S.A., 1958.

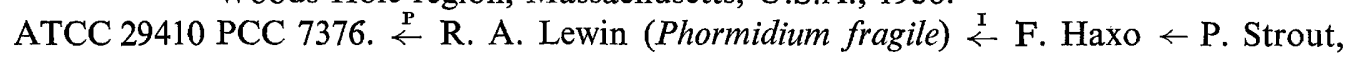
source unknown, 1958.

ATCC 29407 PCC 73110. $\stackrel{P}{\leftarrow}$ M. Shilo $\leftarrow$ UTEX $\leftarrow$ M. Dyar (unidentified filamentous alga no. 3), source unknown (Allen, 1952). Named as Plectonema boryanum in UTEX (594) (Starr, 1964).

ATCC 29165 PCC 7404. $\stackrel{\text { I }}{\leftarrow}$ R. Kunisawa, Lake Washington, U.S.A., 1967.

ATCC 29125 PCC 7406. $\stackrel{\text { I }}{\leftarrow}$ A. Neilson, epiphyte on Azolla filiculoides, Berkeley, California, U.S.A., 1971.

ATCC 29126 PCC 7407. $\stackrel{\text { I }}{\leftarrow}$ SAUG (Microcoleus vaginatus), 1970, source unknown.

ATCC 29344 PCC 7408. \& SAUG, E. G. Pringsheim, 'by river Thames', England, 1940 (Pringsheim, 1951). Named as Pseudanabaena catenata in CCAP (1464/1) (Culture Collection of Algae and Protozoa: List of Strains, 1971), SAUG (1464/1) (Koch, 1964) and UTEX (425) (Starr, 1964).

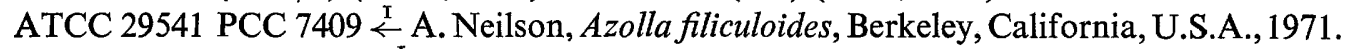

ATCC 29136 PCC 7410. $\stackrel{\text { I }}{\leftarrow}$ A. Neilson, swimming pool, Davis, California, U.S.A., 1972.

ATCC 29127 PCC 7411. $\stackrel{\text { I }}{\leftarrow}$ A. Neilson, sulphide-rich water, Keene Wonder Mine, Death Valley, U.S.A., 1972.

ATCC 29346 PCC 7419. J. B. Waterbury (Lyngbya sp.), salt marsh, Woods Hole, Massachusetts, U.S.A., 1974.

ATCC 29128 PCC 7420. J. B. Waterbury (Microcoleus sp.), salt marsh, Woods Hole, Massachusetts, U.S.A., 1974.

ATCC 29129 PCC 7427. R. Rippka, sphagnum bog, near Kastanienbaum, Vierwaldstättersee, Switzerland, 1972.

ATCC 29170 PCC 7505. $\stackrel{\text { I }}{\leftarrow}$ A. Neilson, moderate hot spring, Amparai District, Maha Oya, Ceylon, 1973.

Table 15 summarizes structural and physiological properties of the 25 strains placed in the LPP group. The range of mean DNA base composition for 24 strains extends from 42 to $59 \mathrm{~mol} \%$ GC (Herdman et al., 1979), without any sharp discontinuity. One exceptional strain, PCC 7411, has a DNA base composition of $67 \mathrm{~mol} \%$ GC.

Seven strains form straight, highly motile trichomes which produce little or no sheath material. In five of them (PCC 7113, 7420, 7105, 7407 and 7411), there are no marked constrictions between adjacent cells of the trichome and some authors would no doubt assign them to the genus Oscillatoria, broadly defined. We have excluded them because the cells of the trichome are cylindrical, not disc-shaped. The trichomes of PCC 7408 and 7409 resemble those of Pseudanabaena, the cylindrical cells being separated by deep constrictions. PCC 7408 was, in fact, identified as Pseudanabaena catenata by its original isolator, E. G. Pringsheim, and is carried impure under this name in the UTEX, CCAP and SAUG collections. Both strains have been excluded from Pseudanabaena because they do not produce polar gas vacuoles. 
Table 15. Properties of strains in the LPP group

$\begin{array}{cc}\text { Cell } & \begin{array}{c}\text { Constric- } \\ \text { tions } \\ \text { width }\end{array} \\ \text { between }\end{array}$

Polar
gas Motil- Facultative photoheterotroph, using:

Synthesis

of nitro-

High

genase Syn- PC

anaero- of (red

Vitamin

$\mathrm{B}_{12}$

$(\mathrm{mol} \% \mathrm{GC})$ no.* group shape $\dagger(\mu \mathrm{m})$ cells Sheath vacuoles ity Glucose Fructose Ribose Sucrose Glycerol biosis C-PE $\ddagger$ colour) Marine $\S$ ment $\|$

\begin{tabular}{|c|c|c|}
\hline$\uparrow$ & 7419 & A \\
\hline & 7420 & B \\
\hline & 7113 & B \\
\hline & 7406 & B \\
\hline & 7375 & B \\
\hline & 7376 & B \\
\hline & 7404 & B \\
\hline & 7427 & B \\
\hline & 7408 & B \\
\hline $42-52$ & 7409 & B \\
\hline & 6306 ) & B \\
\hline & 6402 & B \\
\hline & 73110 & B \\
\hline & 7410 & B \\
\hline & $7505 J$ & B \\
\hline & 7004 & B \\
\hline & 6409 & B \\
\hline & 6703 & B \\
\hline & 7114 & B \\
\hline$\uparrow$ & 7105 & B \\
\hline & $740 ?$ & B \\
\hline $53-59$ & 7123 & B \\
\hline & 7104 & B \\
\hline$\downarrow$ & 7124 & B \\
\hline
\end{tabular}

$\begin{array}{lllll}15-16 & - & + & - & (+)\end{array}$

$4 \cdot 5-5 \cdot 0-$

$3 \cdot 5-4 \cdot 0$

$1 \cdot 5-2 \cdot 0 \quad(+)$

$1 \cdot 0-1 \cdot 5 \quad(+)$

$1 \cdot 3-1 \cdot 8 \quad(+)$

$0 \cdot 8-1 \cdot 3 \quad(+)$

$1 \cdot 0-1 \cdot 5 \quad(+)$

$2 \cdot 0-2 \cdot 5+$

$1 \cdot 0-1 \cdot 5+$

$1 \cdot 8-2 \cdot 3$
$1 \cdot 8-2 \cdot 3$

1.8-2.3 (+)

$\begin{array}{ll}1 \cdot 8-2 \cdot 3 & (+) \\ 1 \cdot 8-2 \cdot 3 & (+)\end{array}$

$\begin{array}{ll}1 \cdot 8-2 \cdot 3 & (+) \\ 1 \cdot 8-2 \cdot 3 & (+)\end{array}$

$1 \cdot 8-2 \cdot 3$

$1 \cdot 8+2 \cdot 3$

$\begin{array}{ll}1 \cdot 8-2 \cdot 3 & (+) \\ 1 \cdot 8-2 \cdot 3 & (+)\end{array}$

1.5-2.0 (+)

2.0-2.5

$1 \cdot 5-2 \cdot 0$

$1 \cdot 0-1 \cdot 5 \quad(+)$

$1 \cdot 0-1 \cdot 5 \quad(+)$

$1 \cdot 0-1 \cdot 5$

(t)

(t) -

(+)

$(+)$

(+)

(t)

$-$

$(+)$
$(+)$

(t)

$(+)$
$(+)$

$(+)$
$(+)$

(+)

$(+)$
$(+)$

$(+)$
$(+)$

(t) \begin{tabular}{l}
- \\
v \\
- \\
$\mathrm{v}$ \\
- \\
- \\
- \\
- \\
- \\
- \\
- \\
$\mathrm{v}$ \\
- \\
- \\
- \\
\hline \\
v \\
$\mathrm{v}$
\end{tabular}

+
+
+
+
+
+
+
+
+
+
+
+
+

-
-


-
-
-
-
+
+
+
+
+
+
+
+
+

$-$

$-$

-

ND

$-$

ND, Not determined; v, variable; $(+)$, present, but not pronounced.

* The bracketed strains are probably independent isolates of the same species.

$\dagger$ d, Disc-shaped; c, cylindrical; i, isodiametric

† C-PE, C-phycoerythrin; PC, phycocyanin.

$\S$ Requirement for high concentrations of $\mathrm{Na}^{+}, \mathrm{Mg}^{2+}$ and $\mathrm{Ca}^{2+}$.

$\| \mathrm{o}$, Obligate requirement for vitamin $\mathrm{B}_{12} ; \mathrm{s}$, vitamin $\mathrm{B}_{12}$ stimulates growth, but is not an obligate requirement. 
In other strains of the LPP group, motility is less evident and appears to be restricted to hormogonia. Strain PCC 7419 (LPP group A) is distinguished by the width of its trichome (15 to $16 \mu \mathrm{m}$ ), composed of disc-shaped cells not separated by marked constrictions. Reproduction occurs by transcellular trichome breakage. Each trichome is enclosed by a firm sheath, a character that might permit assignment of this strain to the genus Lyngbya. In terms of trichome structure, it closely resembles PCC 7515, the reference strain of Oscillatoria.

The remaining 17 strains of the LPP group all produce trichomes less than $3 \mu \mathrm{m}$ wide and composed of cells that are either cylindrical or isodiametric. Some of them (PCC 7406, 7404, 7004,7123 and 7124) have occasionally been observed to form polar gas vacuoles. However, in contrast to Pseudanabaena, gas vacuolation in these strains seems to be variable and is not displayed under all culture conditions. A cluster of freshwater strains (PCC 6306, 6402, 73110,7410 and 7505) appear to be independent isolates of one species. They are structurally indistinguishable (except for the sheathless strain 73110); they synthesize nitrogenase anaerobically; they grow extremely well with glucose, fructose, sucrose and ribose, of which the latter is rarely used by other cyanobacteria; and the DNA base compositional span is narrow (46 to $50 \mathrm{~mol} \%$ GC; Herdman et al., 1979). Strains PCC 6306, 6402 and 73110 were received as Plectonema spp. and the first two strains display rare false branching in old cultures. This structural property is absent from PCC 73110 since it does not form a sheath. Strain PCC 73110 (as Plectonema boryanum 594) has been used for studies on anaerobic nitrogen fixation (Stewart \& Lex, 1970), heterotrophy (Raboy et al., 1976) and the development of cyanophage LPP-1 (Padan et al., 1967; Ginzburg et al., 1968).

Stam \& Venema (1977) have determined by DNA-DNA hybridization in vitro the genetic relatedness of 13 filamentous cyanobacteria known to be hosts for cyanophage LPP-1 (Safferman \& Morris, 1963, 1964) and carried by UTEX. All, including PCC 6306 (UTEX 581) and PCC 73110 (UTEX 594), share such a high level of genetic homology that they can be construed as members of one genospecies. UTEX numbers of genetically related strains not carried in the PCC are: 426, 485, 487, 488, 597, 598 and 790 (axenic), and 427, 482, 595 and 596 (impure). Certain of these strains are listed in the UTEX catalogue as three different species of Plectonema, as two different species of Phormidium and as a Lyngbya sp. Four of the strains examined by Stam \& Venema (UTEX 485, 488, 594 and 597) had also been included in an earlier DNA-DNA hybridization study by Kelly \& Cowie (1971). Kelly \& Cowie's results concerning the genetic relatedness of these strains were similar to those obtained by Stam \& Venema but, in addition, they found the same high degree of homology with a strain of yet another generic assignment: Oscillatoria prolifera (UTEX 1270). No better illustration of the nomenclatural chaos that prevails in this group of cyanobacteria could be provided.

\section{Genera of Section IV}

The 36 strains of this section are assigned to six genera, all long recognized by phycologists. However, many of these genera are defined and distinguished (Table 16, Diagram 2) by developmental properties that have no place in the traditional definitions. These properties are difficult to determine on field material, but are readily evident in pure cultures.

In some genera of Section IV, exemplified by Anabaena Bory de St Vincent 1822, reproduction occurs by random fragmentation of the vegetative trichomes into shorter cell chains that are structurally indistinguishable from the parental trichomes. If akinetes are formed, they germinate to produce short filaments that are likewise structurally indistinguishable from mature vegetative trichomes. In other genera, exemplified by Nostoc Vaucher 1803, reproduction occurs both by random trichome breakage and by the formation of hormogonia. As first described in detail by Harder (1917), hormogonia arise from vegetative cells of the mature trichome under conditions that favour rapid cell division (e.g. transfer to fresh medium). This becomes clearly evident (in medium BG-11 $1_{0}$ ) in Nostoc 
species that produce hormogonia composed of cells that are markedly reduced in size. In such strains the small-celled hormogonia are initially located adjacent to one heterocyst or between two heterocysts that differentiated from the vegetative cells in the mature trichome, and consequently share their larger dimensions (Figs 41, 45). Subsequently, the heterocysts degenerate and the (heterocyst-less) hormogonia are released.

The distinction between Nostoc and Anabaena has been traditionally based on the character of colony formation; however, the gelatinous colonies typical of Nostoc spp. growing under natural conditions are rarely formed in culture. In their descriptions of Nostoc, Bornet \& Flahaut (1888b) and Geitler (1932) imply that strains of this genus undergo a developmental cycle that is absent from Anabaena species. Furthermore, the developmental stages of numerous Nostoc species have been described in detail (Thuret, 1844; Sauvageau, 1897; Harder, 1917; Lazaroff \& Vishniac, 1961; Mollenhauer, 1970). Nevertheless, the presence or absence of a developmental cycle has never been proposed as a discriminatory character. Its taxonomic utility was first recognized by Kantz \& Bold (1969) as the outcome of a comparative study in culture of many strains identified as Nostoc or Anabaena species. They observed that in typical Anabaena strains all trichomes are motile: in typical Nostoc strains, on the other hand, motility is restricted to hormogonia, the cells of which are often smaller than those of the vegetative trichomes. Present observations confirm the validity of this distinction.

A generic differentiation based essentially on motility, however, does not permit the placement of immotile strains, not uncommon in the Nostoc-Anabaena group. In such cases, smaller cell size, gas vacuolation and the absence of heterocysts can serve as additional properties that distinguish hormogonia from mature trichomes. On this basis, strains that produce non-heterocystous immotile hormogonia, either composed of smaller cells than the mature trichomes (PCC 6314, 7524) or containing gas vacuoles (PCC 6719), have been assigned to Nostoc. Although some Nostoc strains are said to divide in a plane parallel to the long axis of the trichome in the course of development (Bornet \& Flahaut, 1888 $b$; Harder, 1917; Geitler, 1932; Lazaroff \& Vishniac, 1961), we have never observed a change in the plane of division in any of the strains included in Nostoc. This observation is confirmed by the fact that none of the Nostoc strains forms lateral heterocysts.

As shown in Table 16, the other genera of Section IV are also distinguishable by hormogonium formation or its absence. Like Anabaena, Cylindrospermum Kützing 1843 and Nodularia Mertens 1822 do not produce hormogonia. These two genera are readily distinguished from Anabaena by the traditional discriminatory properties, always displayed in culture. The vegetative cells in the trichome of Nodularia are disc-shaped, not spherical or cylindrical. The trichomes of Cylindrospermum bear a terminal heterocyst at each end and form subterminal akinetes as growth approaches the stationary phase.

Members of the genus Scytonema Agardh 1824 and Calothrix Agardh 1824 share with Nostoc the ability to form differentiated hormogonia, but their subsequent development diverges from that of Nostoc. In all three genera, the hormogonia are initially devoid of heterocysts. As shown by Kantz \& Bold (1969) and confirmed here, the developing hormogonium of Nostoc soon differentiates two heterocysts, both usually terminal (Figs 39, 43, 53, 54). Subsequent growth and elongation of the hormogonium gives rise to mature trichomes in which intercalary heterocysts may also be produced. In Scytonema and Calothrix only one heterocyst, invariably terminal, is formed in the developing hormogonium (Figs 60, 61, 66, 67).

In Scytonema, growth and elongation of the developing hormogonium eventually leads to the differentiation of trichomes of even width, in which the heterocysts are predominantly intercalary. In Calothrix, the juvenile hormogonia are composed of small cells of even width (Figs 64 to 67). The basal-apical tapering characteristic of this genus is determined by the location of the first terminal heterocyst produced, which is invariably a small one since its development begins at the juvenile stage. However, as development proceeds, the subterminal vegetative cell itself differentiates into a terminal heterocyst, the dimensions of 
Table 16. Section IV: Filamentous heterocystous cyanobacteria that divide in only one plane

\begin{tabular}{|c|c|c|}
\hline \multirow{3}{*}{$\begin{array}{l}\text { Reproduction by random } \\
\text { trichome breakage, and } \\
\text { (in some) by germination } \\
\text { of akinetes, to produce } \\
\text { trichomes indistinguishable } \\
\text { from the mature vegeta- } \\
\text { tive trichomes }\end{array}$} & \multirow{2}{*}{$\begin{array}{l}\text { Heterocysts are intercalary or } \\
\text { terminal; position of akinetes } \\
\text { (if produced) is variable }\end{array}$} & $\begin{array}{l}\text { Vegetative cells are spherical, } \\
\text { ovoid or cylindrical } \\
\text { Anabaena }\end{array}$ \\
\hline & & $\begin{array}{l}\text { Vegetative cells are disc-shaped } \\
\text { Nodularia }\end{array}$ \\
\hline & $\begin{array}{l}\text { Heterocysts are exclusively } \\
\text { terminal and are formed at both } \\
\text { ends of the trichome; akinetes } \\
\text { are always adjacent to } \\
\text { heterocysts }\end{array}$ & $\begin{array}{l}\text { Vegetative cells are iso- } \\
\text { diametric or cylindrical } \\
\qquad \text { Cylindrospermum }\end{array}$ \\
\hline \multirow{3}{*}{$\begin{array}{l}\text { Reproduction as above, } \\
\text { and also by formation of } \\
\text { hormogonia distinguish- } \\
\text { able from mature tri- } \\
\text { chomes by the absence of } \\
\text { heterocysts and by one or } \\
\text { more of the following } \\
\text { characters: rapid gliding } \\
\text { motility, smaller cell size, } \\
\text { cell shape and gas } \\
\text { vacuolation }\end{array}$} & $\begin{array}{l}\text { Hormogonia give rise to young } \\
\text { filaments that bear a terminal } \\
\text { heterocyst at both ends of the } \\
\text { cellular chain }\end{array}$ & $\begin{array}{c}\text { Vegetative cells are spherical, } \\
\text { ovoid or cylindrical; akinetes } \\
\text { (if produced) are not initiated } \\
\text { adjacent to heterocysts and } \\
\text { are often formed in chains } \\
\text { Nostoc }\end{array}$ \\
\hline & \multirow{2}{*}{$\begin{array}{l}\text { Hormogonia give rise to young } \\
\text { filaments that bear a terminal } \\
\text { heterocyst at only one end of } \\
\text { the cellular chain }\end{array}$} & $\begin{array}{l}\text { Mature trichome is composed } \\
\text { of cells of even width; } \\
\text { heterocysts are predominantly } \\
\text { intercalary; vegetative } \\
\text { cells are disc-shaped, iso- } \\
\text { diametric or cylindrical } \\
\text { Scytonema }\end{array}$ \\
\hline & & $\begin{array}{c}\text { Mature trichome tapers from } \\
\text { base, which bears a terminal } \\
\text { heterocyst, to apex; vegetative } \\
\text { cells are disc-shaped, iso- } \\
\text { diametric or cylindrical } \\
\text { Calothrix }\end{array}$ \\
\hline
\end{tabular}

which will depend on the degree of tapering attained at the time of its differentiation. In some strains, a whole series of terminal heterocysts may remain attached to the basal end of the developing trichome, thus demonstrating nicely the course of developmental events (Figs 62, 66). Any break in the filament [e.g. by necridium formation (Lamont, 1969)] may lead to the development of a new terminal heterocyst on one or both sides of the break (Fig. 62). Hormogonia are always formed from the apical end of the trichome. The size of the cells composing hormogonia is constant for any given strain, whereas the size of cells in maturing trichomes increases with age.

From the summary account of the development of Calothrix given above, it follows that cell dimensions of these organisms in the mature (tapering) state are wholly without taxonomic significance: the only reliable estimate of cell size is that determined on the juvenile hormogonium.

The genera Rivularia (Roth 1802) Agardh 1812 and Gloeotrichia Agardh 1842 are traditionally distinguished from Calothrix Agardh 1824 by their development under natural conditions as gelatinous, usually hemispherical, colonies (composed of non-akinete forming and akinete producing tapered trichomes, respectively). Strains PCC 7111, 7116 and 7204 were isolated from natural colonies identified as Rivularia spp. but do not produce gelatinous colonies in culture. They have accordingly become indistinguishable from Calothrix spp. and are included in this genus. 
(a)
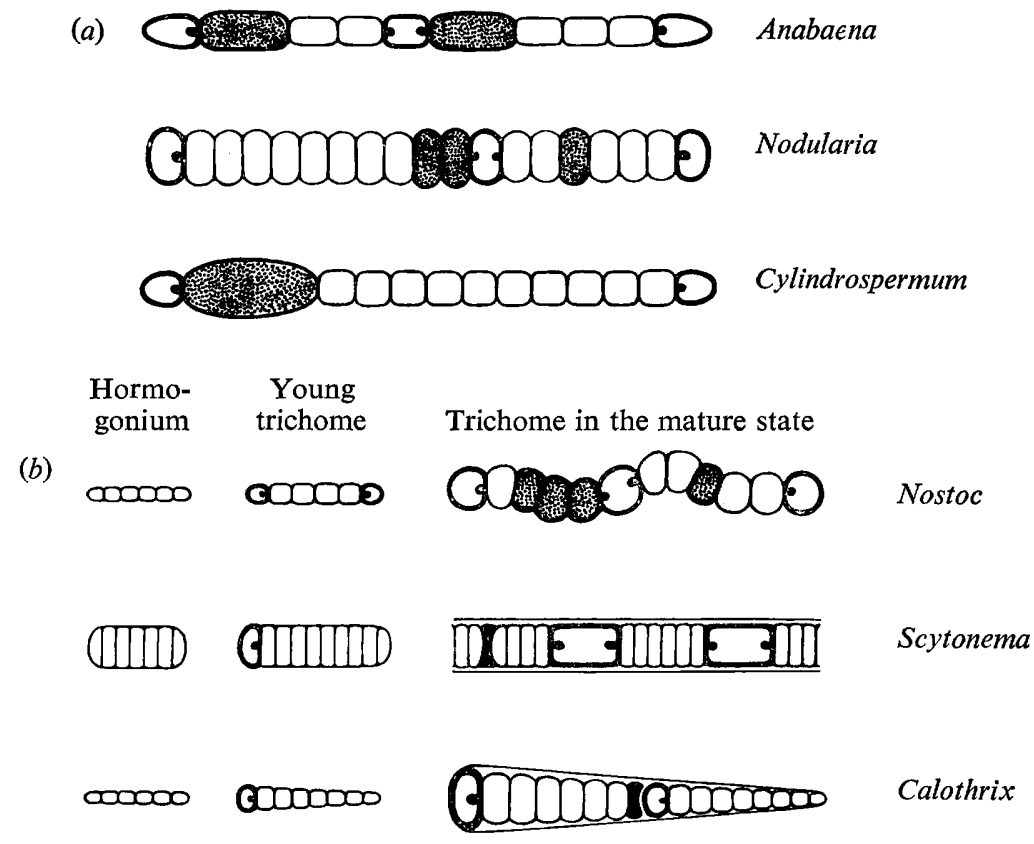

Diagram 2. Schematic presentation of the genera assigned to Section IV: $(a)$ without developmental cycle; $(b)$ with developmental cycle. Heavy walled cells with polar granules represent heterocysts; heavy walled cells that are dotted represent akinetes; thin lines surrounding trichomes designate sheath material.

Genera based on the occurrence of coiled and multiple trichomes enclosed by a common sheath (e.g. Dichothrix Zanardini 1858 and Polythrix Zanardini 1872) have also been ignored, since our observations suggest that this phenomenon is a crowding effect of rapidly growing trichomes within a firm sheath and therefore of no taxonomic value (Fig. 63).

The mean DNA base composition characteristic of all heterocystous cyanobacteria is narrow: values for the 36 strains of Section IV range from 38 to $47 \mathrm{~mol} \%$ GC (Herdman et al., 1979). This character is of little value for making either intergeneric or intrageneric distinctions.

\section{Genus Anabaena Bory de St Vincent 1822}

Examples of this genus (PCC 7120 and 7122) are shown in Figs 33 and 34. Two strains (PCC 7119 and 7120) were originally described as Nostoc muscorum (Adolph \& Haselkorn, 1971) but do not possess the character of the genus Nostoc as defined here. Strain PCC 7118, originally identified as Anabaena variabilis (Kratz \& Myers, 1955), has been incapable of fixing nitrogen or forming heterocysts in culture for over 20 years (Kratz \& Myers, 1955; Leach \& Carr, 1971). Its identity as an Anabaena sp. was recently confirmed by the isolation of a spontaneous heterocystous mutant, capable of aerobic nitrogen fixation (Rippka \& Stanier, 1978). The strain histories are as follows:

ATCC 29211 PCC 6309 (Kenyon et al., 1972). $\stackrel{\text { I }}{\leftarrow}$ M. Shilo $\leftarrow$ UTEX, source unknown. Named as Anabaena variabilis Kütz. in UTEX (377) (Starr, 1964) and in CCAP (1403/4b) (Culture Collection of Algae and Protozoa: List of Strains, 1971); named as Anabaena cylindrica Lemm. in SAUG (1403/4b) (Pringsheim, 1951).

ATCC 27898 PCC 6411 (Kenyon et al., 1972). M. M. Allen, pond water, California, U.S.A., 1964. Named as Nostoc sp. in UTEX (1597) (Starr, 1971). 

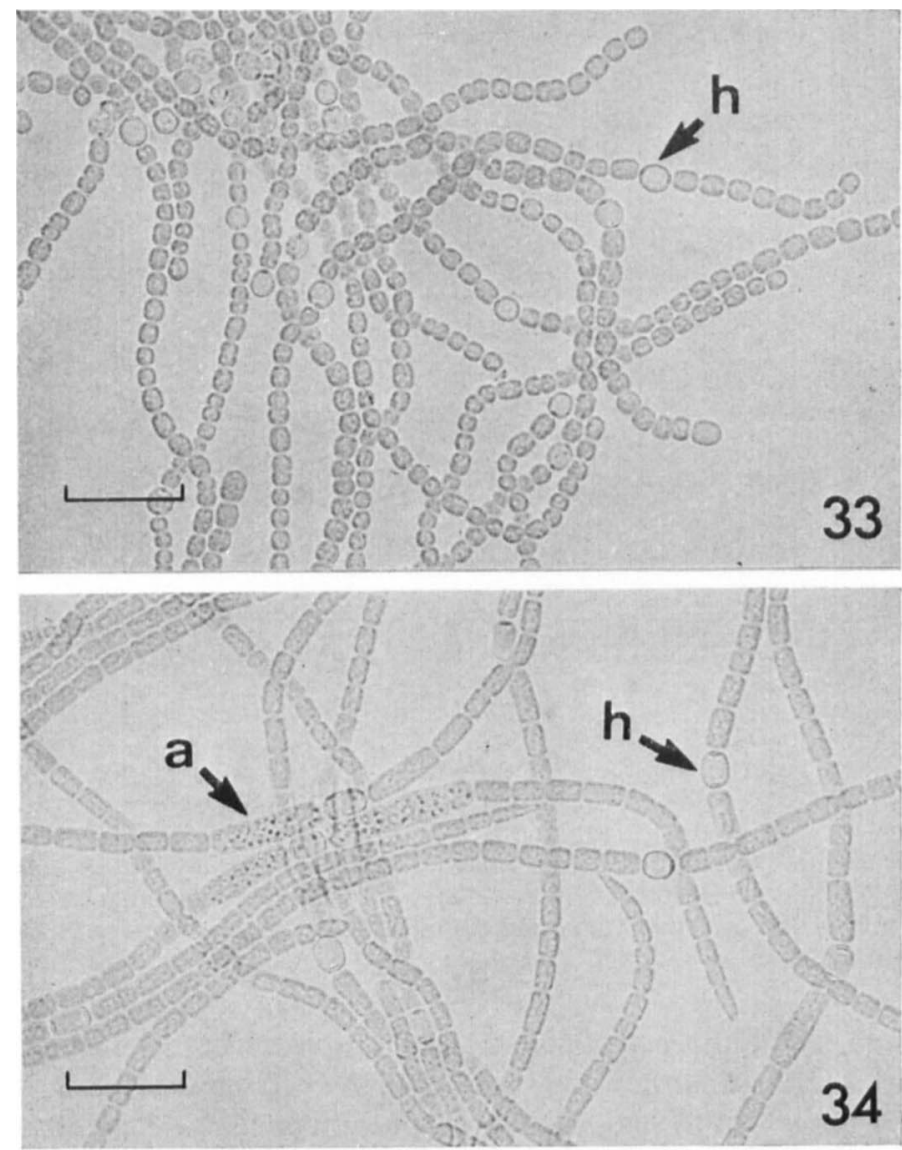

Figs 33 and 34. Anabaena PCC 7120 and PCC 7122, respectively: h, heterocysts; a, akinetes. Both bright field; bar markers represent $20 \mu \mathrm{m}$.

ATCC 29208 PCC 7108. J. B. Waterbury, intertidal zone, Moss Beach, California, U.S.A. 1970.

ATCC 27892 PCC 7118. $\stackrel{\text { P }}{\leftarrow}$ N. G. Carr $\stackrel{\text { P}}{\leftarrow}$ J. Myers (Anabaena variabilis Kütz.) $\leftarrow$ R. C. Hecker (Cylindrospermum sp.), source unknown (Kratz \& Myers, 1955).

ATCC 29151 PCC 7119. $\stackrel{P}{\leftarrow}$ R. Haselkorn $\stackrel{P}{\leftarrow}$ University of Wisconsin (Nostoc muscorum UW), source unknown (Adolph \& Haselkorn, 1971).

ATCC 27893 PCC $7120 . \stackrel{\text { P }}{\leftarrow}$ R. Haselkorn $\stackrel{\text { P }}{\leftarrow}$ Iowa State University (Nostocmuscorum ISU), source unknown (Adolph \& Haselkorn, 1971).

ATCC 27899 PCC 7122. $\stackrel{\text { P }}{\leftarrow}$ D. Arnon $\stackrel{\text { P }}{\leftarrow}$ UTEX $\stackrel{P}{\leftarrow}$ G. E. Fogg $\stackrel{\text { P }}{\leftarrow}$ S. P. Chu, pond water, Cambridge, England, 1939 (Fogg, 1942). Named as Anabaena cylindrica Lemm. in CCAP (1403/2a) (Culture Collection of Algae and Protozoa: List of Strains, 1971), SAUG (1403/2) (Pringsheim, 1951), UTEX (629) (Starr, 1964).

All strains assigned to Anabaena are obligate autotrophs. The range of mean DNA base composition is 38 to $44 \mathrm{~mol} \%$ GC (Herdman et al., 1979). As shown in Table 17, they are divisible into two sub-groups, each of which shares many common properties. The bracketed strains are almost certainly independent isolates of a single species. In strains that form akinetes, these always develop from vegetative cells adjacent to a heterocyst.

\section{Reference strain: PCC 7122}


Table 17. Properties of Anabaena strains

\begin{tabular}{|c|c|c|c|c|c|c|}
\hline PCC no.* & Motility & $\begin{array}{l}\text { Conical } \\
\text { end cells }\end{array}$ & $\begin{array}{l}\text { Akinetes } \\
\text { produced }\end{array}$ & $\begin{array}{c}\text { Lysed by } \\
\text { phage } \\
\mathrm{N}-1 \dagger\end{array}$ & $\begin{array}{c}\text { Synthesis } \\
\text { of } \\
\text { PEC } \$\end{array}$ & $\begin{array}{l}\text { Grows as } \\
\text { even } \\
\text { suspension } \\
\text { in liquid } \\
\text { culture }\end{array}$ \\
\hline $\begin{array}{l}6411 \\
7118\end{array}$ & - & - & - & + & + & + \\
\hline 7118 & - & - & - & + & + & + \\
\hline $7119 \mid$ & - & - & - & + & + & + \\
\hline $7120 /$ & - & - & - & + & + & + \\
\hline 6309$\}$ & + & + & + & - & + & - \\
\hline 7122$\}$ & + & + & + & - & + & - \\
\hline 7108 & + & + & + & - & + & - \\
\hline
\end{tabular}

All strains are obligate photoautotrophs.

* Bracketed strains are probably independent isolates of the same species.

$\uparrow$ Spot test on a lysate produced by the host strain Anabaena PCC 7120.

† PEC, Phycoerythrocyanin.
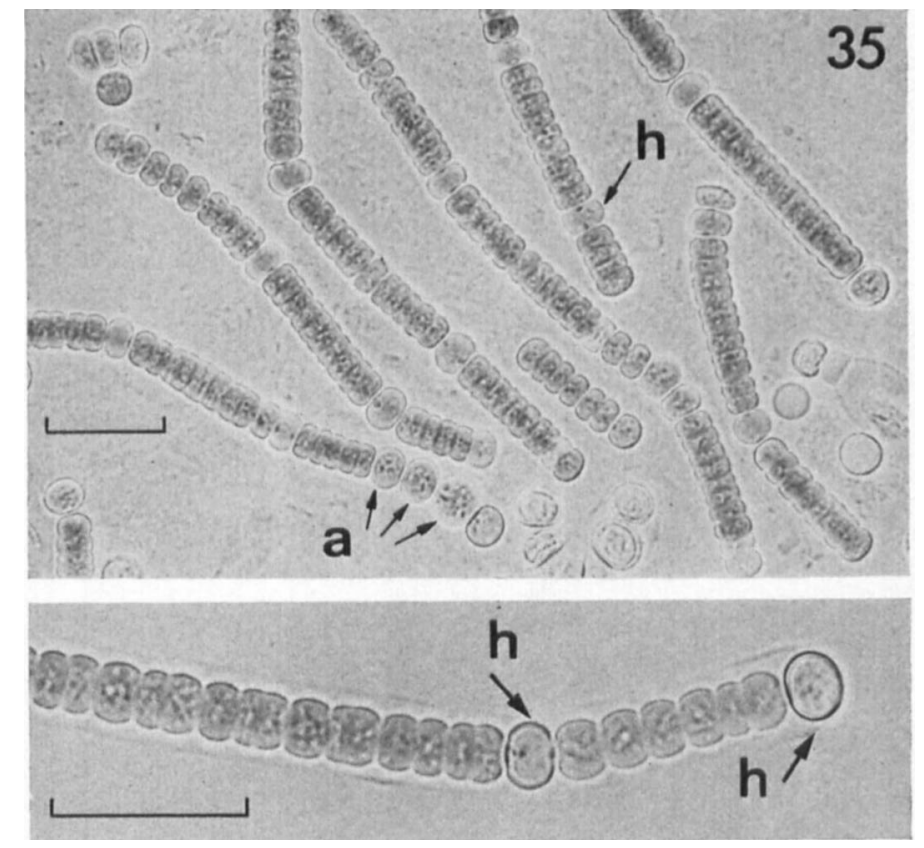

Fig. 35. Nodularia PCC 73104: h, heterocysts; a, akinetes. Bright field; bar markers represent $20 \mu \mathrm{m}$.

\section{Genus Nodularia Mertens 1822}

Only one strain of this genus is represented in the PCC collection; it is illustrated in Fig. 35. ATCC 29167 PCC 73104. $\stackrel{\text { I }}{\leftarrow}$ R. N. Nordin, highly alkaline pond, British Columbia, Canada.

This strain is a facultative heterotroph which grows with glucose, fructose and, more poorly, with sucrose. The mean DNA base composition is $40.5 \mathrm{~mol} \% \mathrm{GC}$ (Herdman et al., 1979). Heterocysts are predominantly intercalary; akinetes are formed, often in chains, either adjacent to heterocysts or distant from them. No phycoerythrinoid pigment is formed. Although this strain can synthesize nitrogenase aerobically, aerobic growth at the expense of $\mathrm{N}_{2}$ is very slow. 


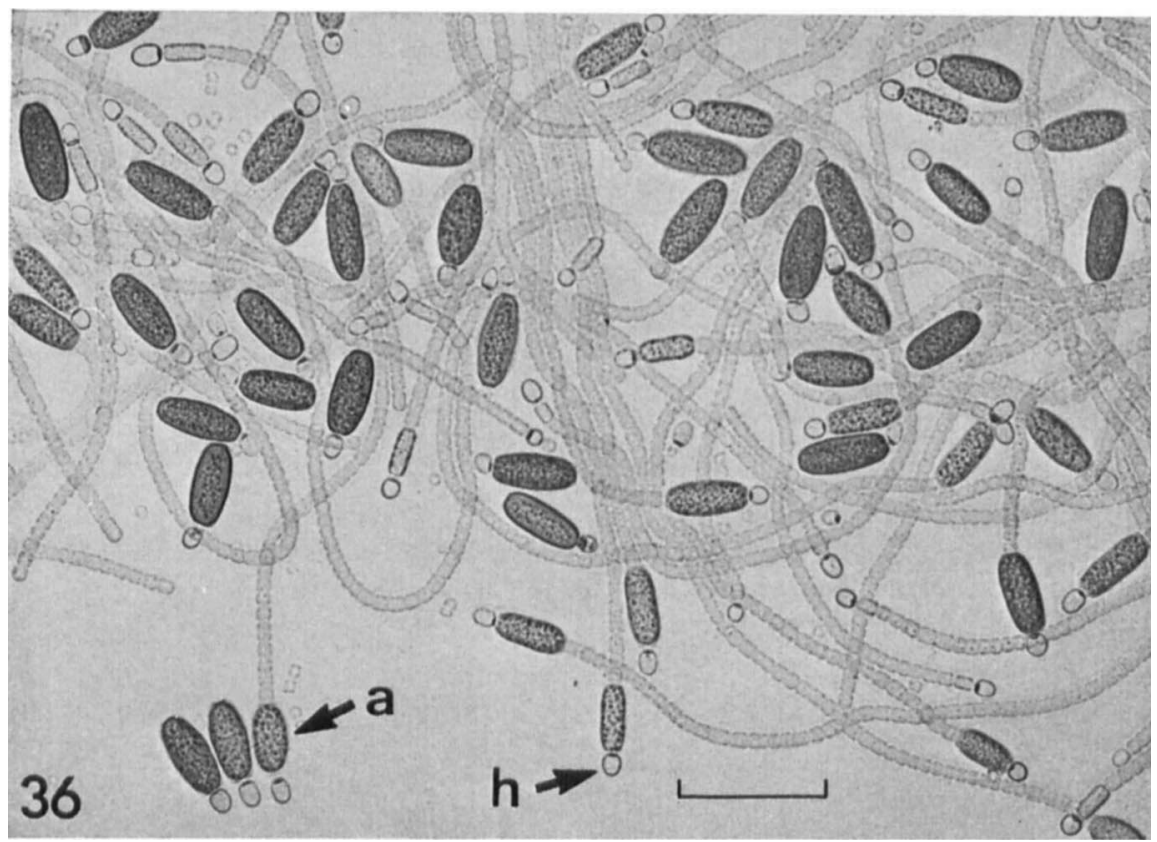

Fig. 36. Cylindrospermum PCC 73101: h, heterocysts; a, akinetes. Bright field; bar marker represents $50 \mu \mathrm{m}$.
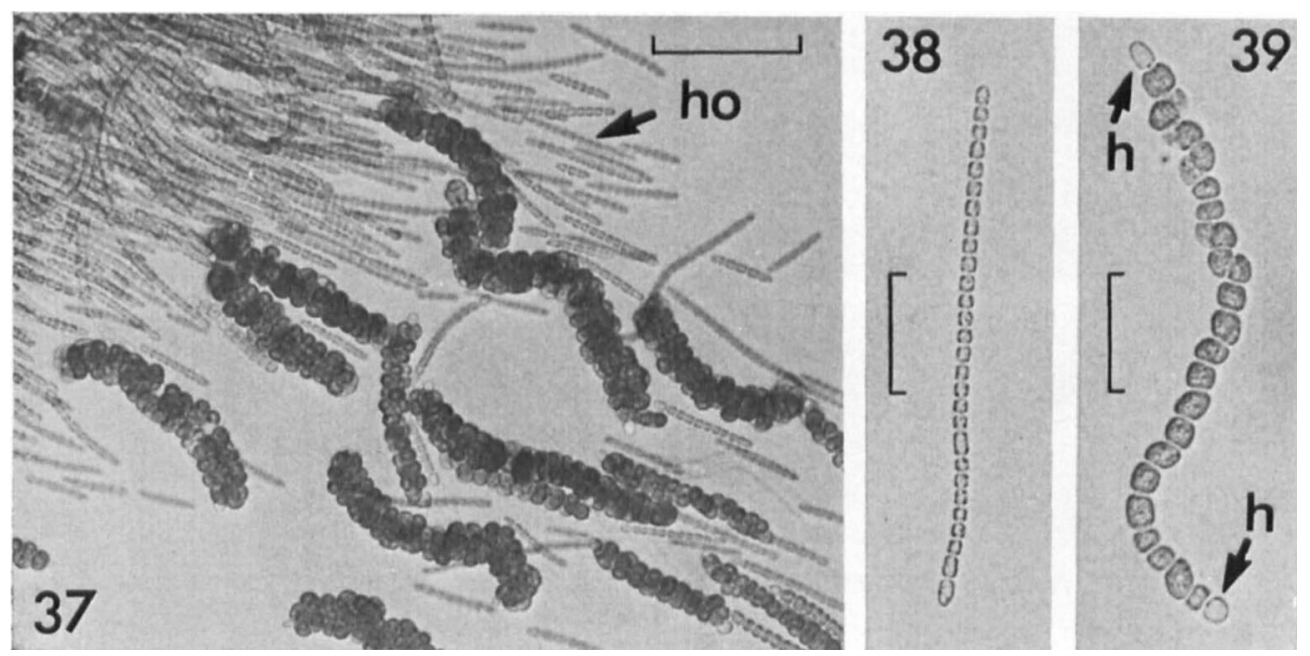

Figs 37 to 39. Nostoc PCC 73102. Fig. 37 shows coiled vegetative filaments together with hormogonia (ho). Fig. 38 shows an enlarged view of a hormogonium, and Fig. 39 shows a mature, but still uncoiled vegetative trichome, with terminal heterocysts (h). All bright field; bar markers represent $50 \mu \mathrm{m}$ in Fig. 37 and $20 \mu \mathrm{m}$ in Figs 38 and 39. 


\section{Genus Cylindrospermum Kützing 1843}

One of the three strains in this genus (PCC 73101) is shown in Fig. 36. The histories of the strains are as follows:

ATCC 29535 PCC 73101. $\stackrel{\text { I }}{\leftarrow}$ SAUG Cylindrospermum stagnale; source unknown.

ATCC 29204 PCC 7417. $\stackrel{\text { r }}{\leftarrow}$ A. Neilson, soil, greenhouse, Stockholm, Sweden, 1972.

ATCC 33001 PCC 7604. $\stackrel{\mathrm{I}}{\leftarrow}$ M. Wilcox [Cylindrospermum maius (CCAP 415/2) (Culture Collection of Algae and Protozoa: List of Strains, 1971)] $\leftarrow$ J. Komarek.

The three strains are similar in structure. The range of DNA base composition is 42 to $47 \mathrm{~mol} \%$ GC (Herdman et al., 1979). Strains PCC 73101 and 7604 are obligate autotrophs whereas 7417 is a facultative heterotroph that grows on fructose and sucrose. All produce phycoerythrocyanin.

Reference strain: PCC 7417

\section{Genus Nostoc Vaucher 1803}

The diversity of the strains comprising this genus and some aspects of their developmental processes are illustrated in Figs 37 to 58. Several strains included in this genus were received under other generic designations: PCC 6302 and 6310 as Anabaena spp., 6720 as Anabaenopsis and 7413 as Cylindrospermum. Partial descriptions of several strains, designated as 'Anabaena-type', are given in Kenyon et al. (1972). The strain histories are as follows:

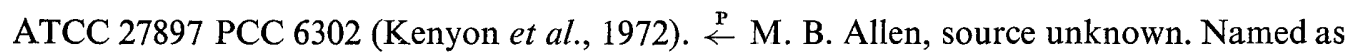
Anabaena sp. in UTEX (1551) (Starr, 1966).

ATCC 27896 PCC 6310 (Kenyon et al., 1972). $\stackrel{\text { I }}{\leftarrow}$ M. Shilo (Anabaena spiroides), fish pond, Northern Galilee, Israel, 1963. In UTEX (1552) (Starr, 1966).

ATCC 27904 PCC 6314 (Kenyon et al., 1972). M. M. Allen, crude algal material, 1963. Named as Nostoc muscorum in UTEX (1545) (Starr, 1966).

ATCC 29131 PCC 6705 (Kenyon et al., 1972). $\stackrel{\text { I }}{\leftarrow}$ G. Cohen-Bazire, Botanical Garden, University of California, Berkeley, U.S.A., 1967.

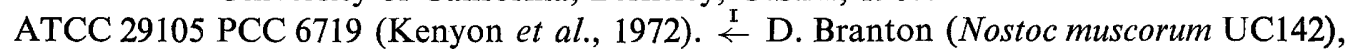
soil water culture, microgarden collection, University of California, Berkeley, U.S.A. (Waaland \& Branton, 1969; Waaland et al., 1970).

ATCC 27895 PCC 6720 (Kenyon et al., 1972). $\stackrel{\mathrm{P}}{\leftarrow}$ R. A. Lewin $\stackrel{P}{\leftarrow}$ A. Watanabe (Anabaenopsis circularis), soil sample, Sumatra, 1950 (Watanabe, 1959). In CCAP (1402/1) (Culture Collection of Algae and Protozoa: List of Strains, 1971).

ATCC 29150 PCC 7107. A. Neilson, shallow pond, Point Reyes Peninsula, California, U.S.A., 1970.

ATCC 29133 PCC 73102. R. Rippka, root section, Macrozamia sp., Australia, 1973.

ATCC 29106 PCC 7413. $\stackrel{\text { I }}{\leftarrow}$ G. E. Fogg (Cylindrospermum licheniforme), surface garden soil, St Albans, Hertfordshire, England, 1950 (purified by ultraviolet radiation).

ATCC 29107 PCC 7416. A. Neilson, shallow pool, San Andreas valley, California, U.S.A., 1972.

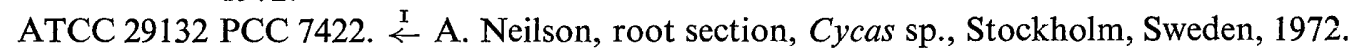

ATCC 29168 PCC 7423. ㄴ $\leftarrow$ P. Roger, dried soil sample, Senegal, 1973.

ATCC 29411 PCC 7524. $\stackrel{\text { I }}{\leftarrow}$ A. Neilson, moderate hot spring, Amparai District, Maha Oya, Ceylon, 1973.

The range of mean DNA base composition for the 13 Nostoc strains is very narrow: 39 to $45 \mathrm{~mol} \%$ GC (Herdman et al., 1979). In phenotypic respects (Table 18) the strains appear highly diverse: only PCC 7107 and 7416 are sufficiently similar to suggest that they are independent isolates of a single species. Most strains produce akinetes, often formed in 

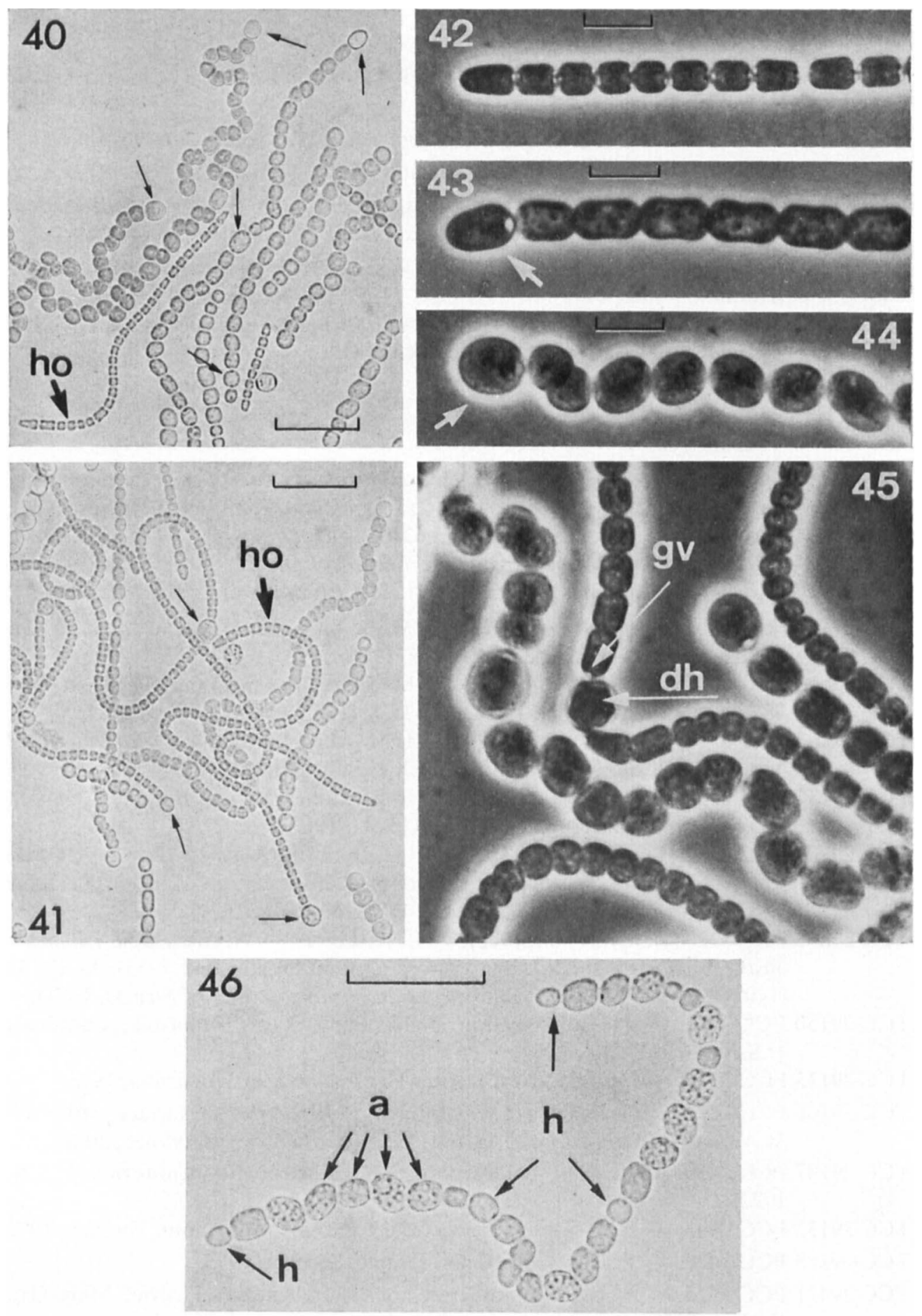

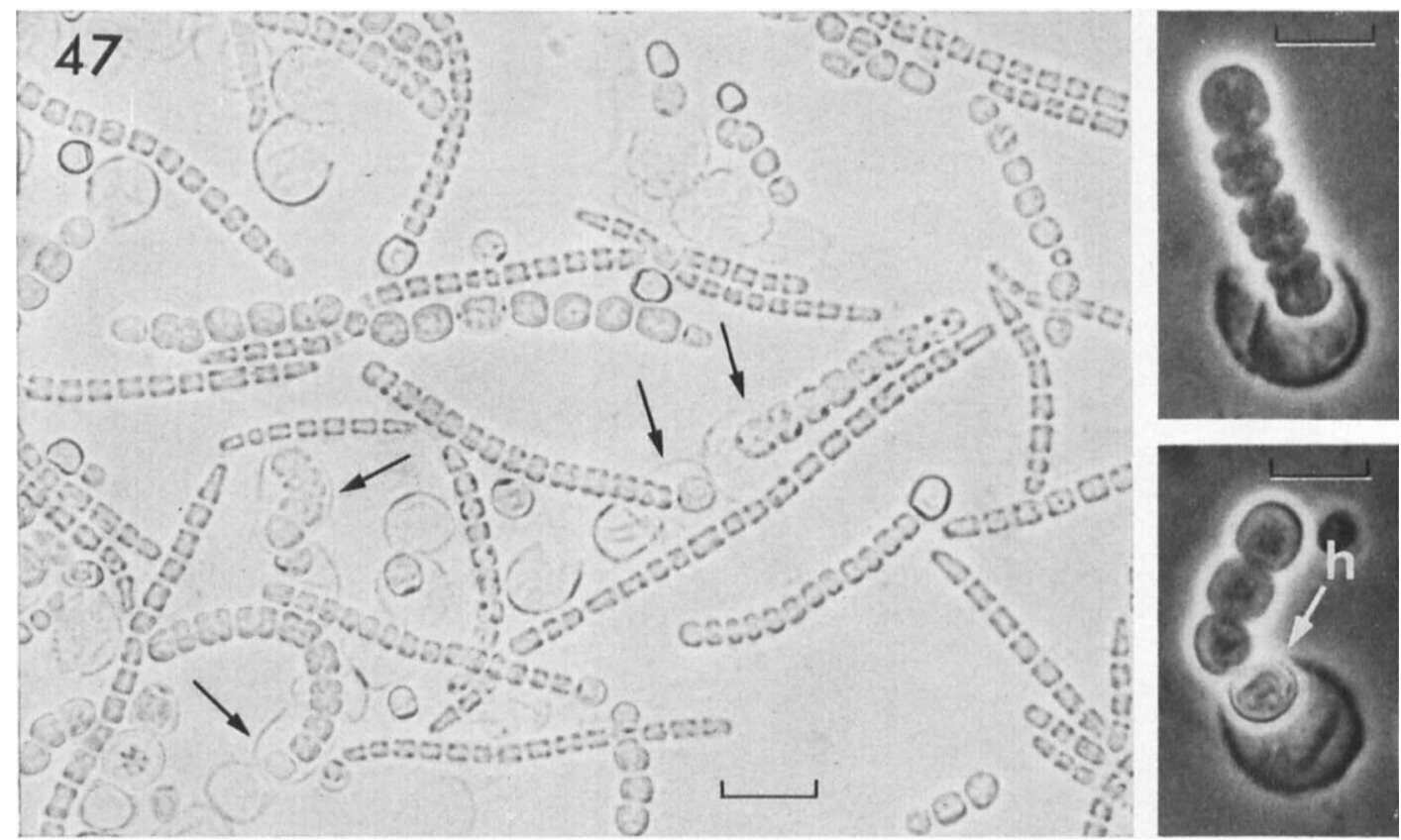

Fig. 47. Nostoc PCC 6720. Germination of akinetes (arrows). Note that germination does not give rise to a differentiated hormogonium (in this strain characterized by polar gas vacuoles, Fig. 42) but to a short trichome composed of cells that differ little from the cells in a vegetative trichome. Heterocysts (h) may be formed at a relatively early stage of akinete germination. Bright field (insets, phase contrast); bar marker represents $10 \mu \mathrm{m}$ (insets, $5 \mu \mathrm{m}$ ).

chains. Akinete development is never initiated adjacent to heterocysts, as it is in the akineteproducing strains of Anabaena carried in the PCC. The majority of strains are photoheterotrophs. Most strains produce either C-phycoerythrin or phycoerythrocyanin. PCC 6302,6314 and 7524 have lost the ability to fix nitrogen aerobically as a result of prolonged cultivation in medium BG-11. Dark growth and chromatic light have been reported to influence the developmental cycle of Nostoc muscorum (Lazaroff, 1966) and Nostoc commune 584 (Robinson \& Miller, 1970). A systematic survey of these parameters on Nostoc strains in the PCC collection is in progress.

\section{Reference strain: PCC 73102}

Figs 40 to 46. Nostoc PCC 6720. Fig. 40 shows mature filaments and hormogonia (ho); arrows indicate heterocysts. Bright field. Fig. 41 shows the formation of hormogonia (ho) next to heterocysts (arrows) that differentiated from the vegetative cells in the mature trichome and consequently share their larger dimensions. Bright field. Figs 42 to 44 show the successive developmental stages of a freshly released hormogonium to a mature vegetative trichome. Note the resemblance of the hormogonium (Fig. 42) to a Pseudanabaena species (intercellular constrictions, polar gas vacuoles) as well as the cellular enlargement, loss of gas vacuolation and the formation of heterocysts (arrows) that accompany hormogonial development (Figs 43, 44). Phase contrast. Fig. 45 shows a degenerating intercalary heterocyst (dh) from which a rapidly dividing, newly formed hormogonium will subsequently detach; gas vacuoles (gv) are already present in the cells adjacent to the heterocyst. Phase contrast. Fig. 46 shows a mature trichome with rows of akinetes (a). As typical for Nostoc (Bornet \& Flahaut, 1888b), akinete differentiation is initiated midway between two heterocysts (h), never adjacent to a heterocyst. Successive akinete differentiation on both sides of the first akinete produced may eventually also lead to akinetes that are adjacent to heterocysts. Bright field. Bar markers represent $20 \mu \mathrm{m}$ in Figs 40,41 and 46 and $5 \mu \mathrm{m}$ in Figs 42 to 45 . 

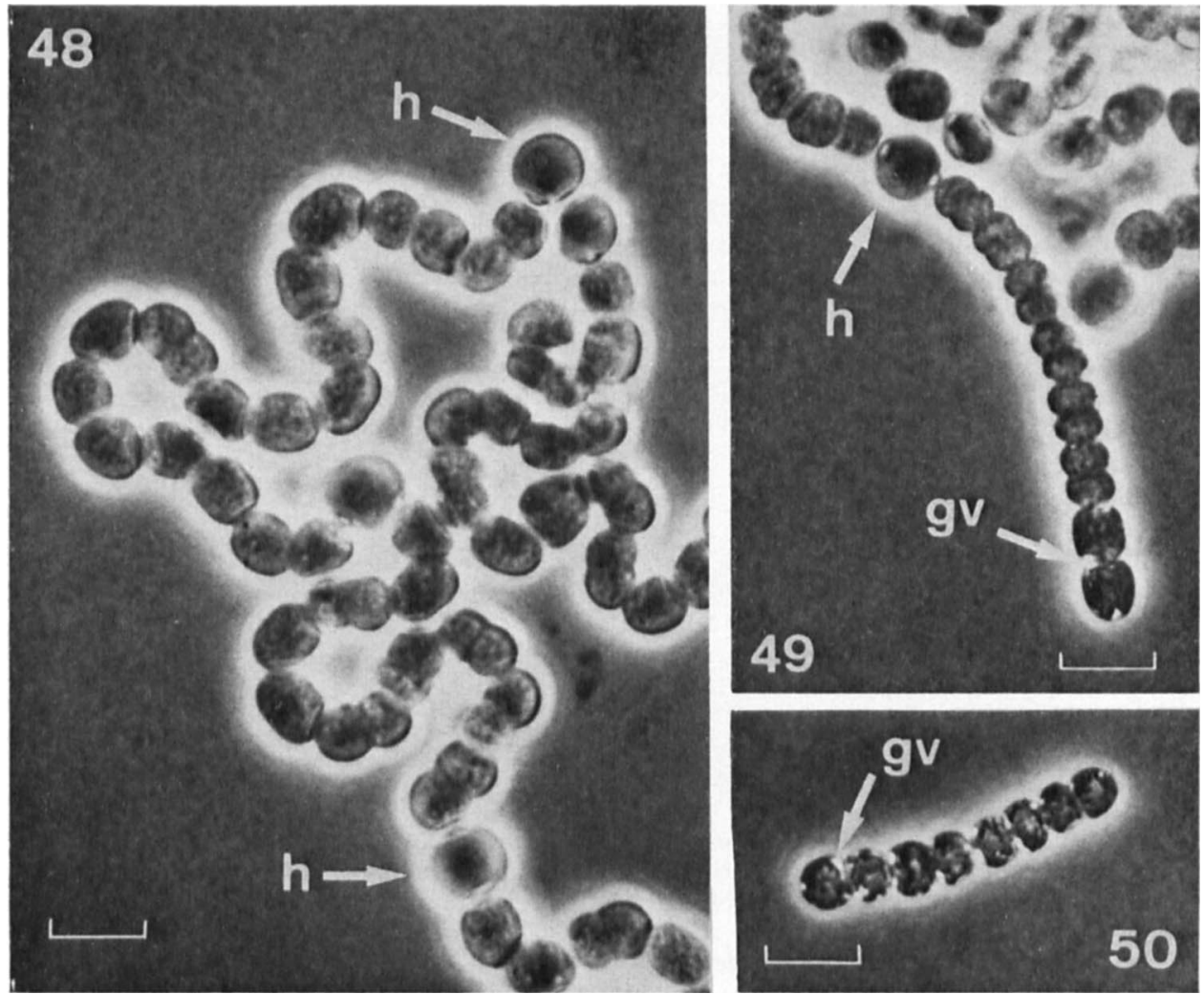

Figs 48 to 50. Nostoc PCC 6705, a strain that produces hormogonia containing irregularly distributed gas vacuoles (gv). Fig. 48 shows mature trichomes with terminal and intercalary heterocysts (h). Fig. 49 shows the manner of hormogonium formation immediately prior to its release. Fig. 50 shows a short gas vacuolated hormogonium. All phase contrast; bar markers represent $5 \mu \mathrm{m}$.

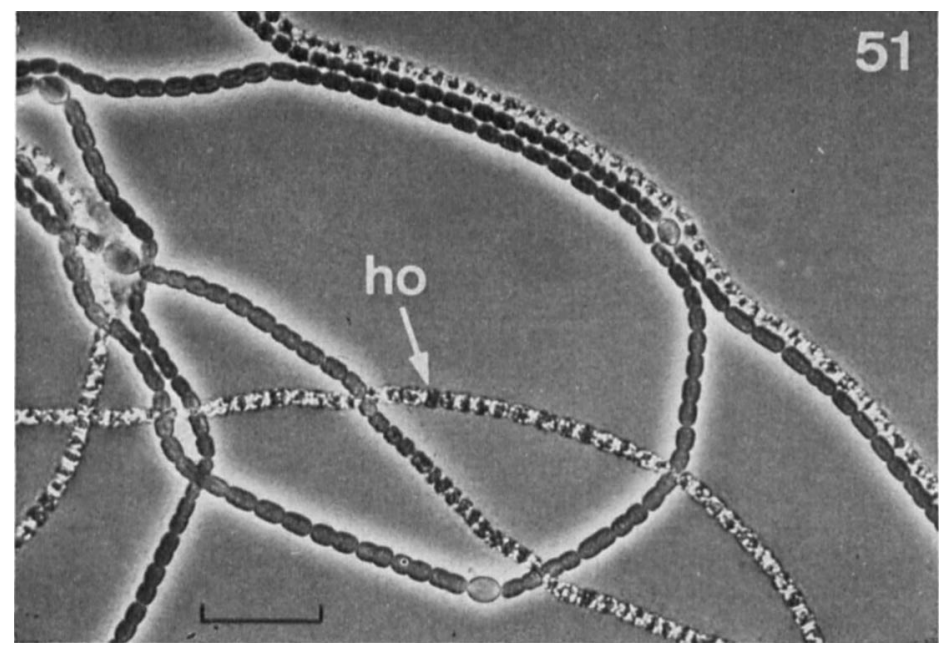

Fig. 51. Nostoc PCC 6719 (strain of Waaland \& Branton, 1969), showing the long, gas vacuolated hormogonia (ho) that are characteristic of this strain. Phase contrast; bar marker represents $20 \mu \mathrm{m}$. 

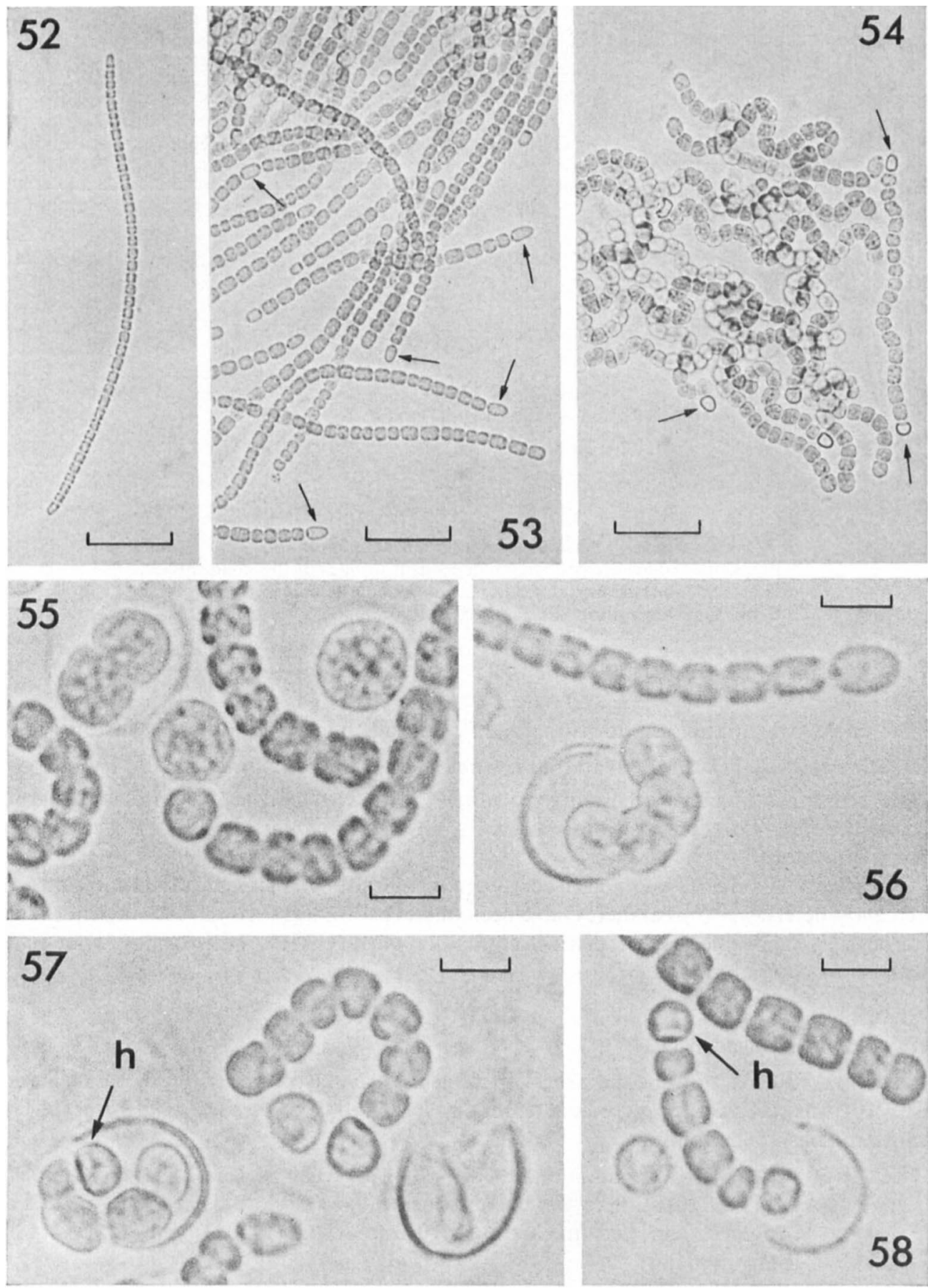

Figs 52 to 58. Nostoc PCC 7107. Figs 52 to 54 show the development of a hormogonium to a mature vegetative trichome; arrows indicate heterocysts. Figs 55 to 58 show stages in the germination of akinetes: two-celled stage (Fig. 55); four-celled stage (Fig. 56); five-celled stage, including a heterocyst (h) (Fig. 57); six-celled stage, including a heterocyst (h) (Fig. 58). All bright field; bar markers represent $20 \mu \mathrm{m}$ in Figs 52 to 54 and $5 \mu \mathrm{m}$ in Figs 55 to 58 . 
Table 18. Properties of Nostoc strains

\begin{tabular}{|c|c|c|c|c|c|c|c|c|c|c|}
\hline \multirow{2}{*}{$\begin{array}{l}\text { PCC } \\
\text { no.* }\end{array}$} & \multirow{2}{*}{$\begin{array}{l}\text { Perma- } \\
\text { nently } \\
\text { immotile }\end{array}$} & \multirow{2}{*}{$\begin{array}{l}\text { Hormo- } \\
\text { gonia } \\
\text { gas } \\
\text { vacuo- } \\
\text { lated } \dagger\end{array}$} & \multirow{2}{*}{$\begin{array}{l}\text { Akinetes } \\
\text { pro- } \\
\text { duced }\end{array}$} & \multirow{2}{*}{$\begin{array}{l}\text { Trichomes } \\
\text { break up } \\
\text { in old } \\
\text { cultures } \\
\text { into } \\
\text { isolated } \\
\text { cells }\end{array}$} & \multicolumn{4}{|c|}{$\begin{array}{l}\text { Facultative photoheterotroph, } \\
\text { using: }\end{array}$} & \multicolumn{2}{|c|}{$\begin{array}{l}\text { Synthesis } \\
\text { of: }\end{array}$} \\
\hline & & & & & Glucose & Fructose & Ribose & Sucrose & C-PE & PEC \\
\hline 6302 & - & - & + & - & + & + & + & + & + & - \\
\hline 6310 & - & - & + & - & + & + & $(+)$ & + & + & - \\
\hline 6314 & + & - & + & + & - & - & - & $+^{v}$ & - & + \\
\hline 6705 & - & $t^{1}$ & + & - & - & - & - & $+^{v}$ & - & + \\
\hline 6719 & + & $+^{1}$ & - & - & - & - & - & - & - & + \\
\hline 6720 & - & $t^{2}$ & + & - & + & + & - & - & - & + \\
\hline 7107 & - & - & + & - & - & + & - & - & - & + \\
\hline 7416$\}$ & - & - & + & - & - & + & - & - & - & + \\
\hline 73102 & - & $t^{2}$ & + & - & + & + & + & $(+)$ & + & - \\
\hline 7413 & - & - & - & - & - & - & - & - & - & - \\
\hline 7422 & - & - & - & - & - & - & - & - & + & - \\
\hline 7423 & + & - & + & - & - & + & - & - & - & - \\
\hline 7524 & + & - & + & + & - & - & - & + & - & + \\
\hline
\end{tabular}

$(+)$, Weak growth; $+^{\nabla}$, variable, probably reflecting mutation.

* Bracketed strains are probably independent isolates of the same species.

$\dagger 1$, Gas vacuoles throughout cells; 2 , gas vacuoles confined to cell poles.

¥ C-PE, C-phycoerythrin; PEC, phycoerythrocyanin.

\section{Genus Scytonema Agardh 1824}

The one representative is shown in Figs 59 and 60. It has the following history:

ATCC 29171 PCC 7110. J. B. Waterbury, Crystal Cave (limestone), Bermuda, 1971.

This strain is a facultative heterotroph which grows with glucose, fructose and sucrose. The mean DNA base composition is $44 \mathrm{~mol} \%$ GC (Herdman et al., 1979). Phycoerythrocyanin is produced.

The mature filaments, characterized by frequent false branching, produce cylindrical intercalary heterocysts; no akinetes have been observed. In hormogonia, the single terminal heterocyst is hemispherical. A distinctive feature of PCC 7110, best displayed on plate cultures, is its aerial growth.

\section{Genus Calothrix Agardh 1824}

Structural features of some members of this genus are illustrated in Figs 61 to 69. Strain PCC 7101 was received as Tolypothrix tenuis and PCC 7103 as Nodularia sphaerocarpa. The strain histories are as follows:

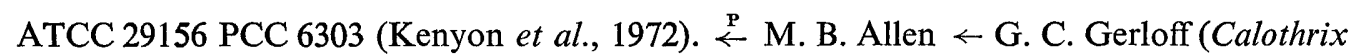
purietina 1018), lake water, Wisconsin, 1948 (Gerloff et al., 1950). Named as Calothrix parietina in CCAP (1410/3), SAUG (1410/3) and UTEX (484) (Starr, 1964).

ATCC 27914 PCC 7101 (Kenyon et al., 1972). $\stackrel{\text { P }}{\leftarrow}$ SAUG $(1482 / 3)($ Koch, 1964) $\stackrel{\text { P }}{\leftarrow}$ A. Watanabe (Tolypothrix tenuis Kütz.), soil sample, Borneo, 1950 (Watanabe, 1959). In CCAP (1482/3a and 1482/3b) (Culture Collection of Algae and Protozoa: List of Strains, 1971).

ATCC 27901 PCC 7102 (Kenyon et al., 1972). $\stackrel{\text { I }}{\leftarrow}$ SAUG $\stackrel{\text { x}}{\leftarrow}$ G. H. Schwabe (Calothrix desertica), fine desert sand, near La Pertada, Antofagasta, Chile, 1958 (Schwabe, 1960). 

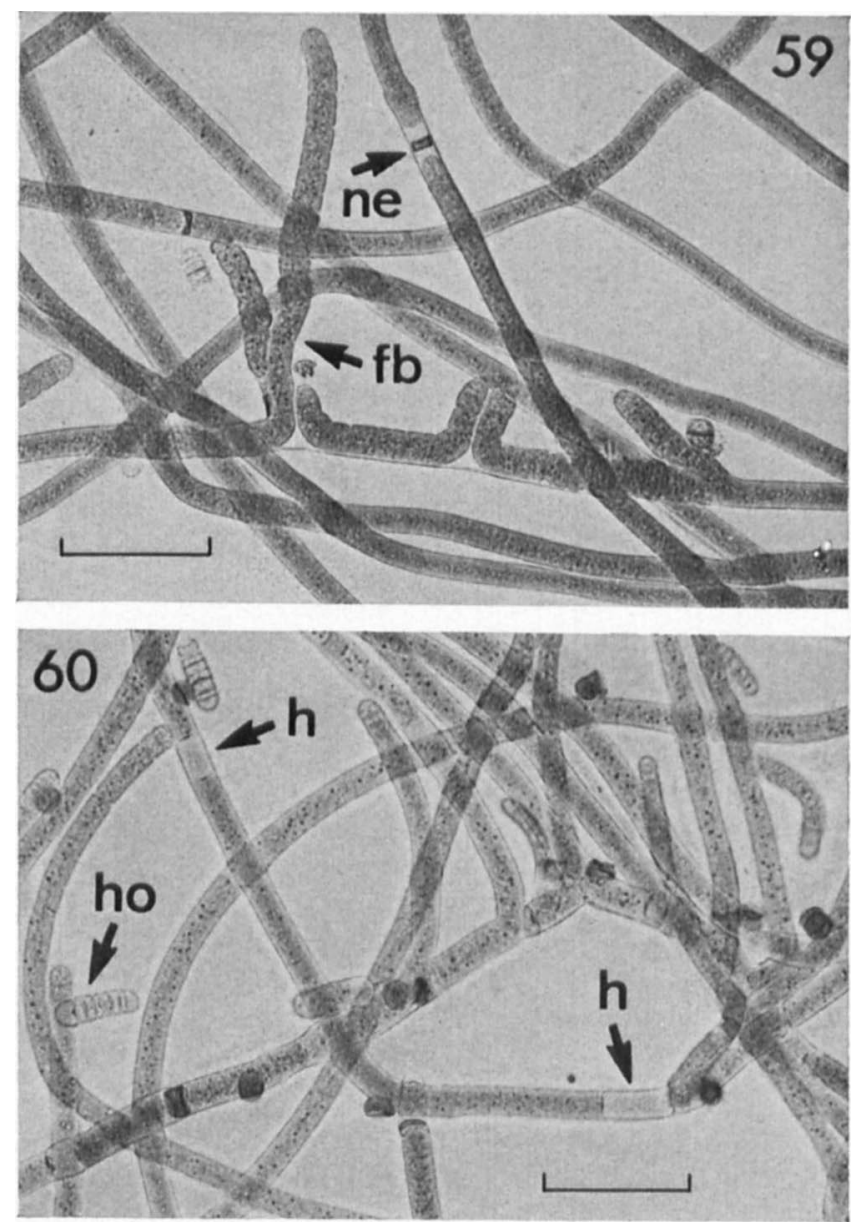

Figs 59 and 60. Scytonema PCC 7110, grown in BG-11 (Fig. 59) and BG-11 (Fig. 60), showing necridia (ne) and false branching (fb) (Fig. 59) and mature trichomes with intercalary heterocysts (h) and a short hormogonium (ho) bearing a terminal heterocyst (Fig. 60). Both bright field; bar markers represent $50 \mu \mathrm{m}$.

ATCC 27905 PCC 7103 (Kenyon et al., 1972). $\stackrel{\text { I }}{\leftarrow}$ SAUG (1466/1) Nodularia sphaerocarpa (Koch, 1964) $\leftarrow$ M. B. Allen, source unknown. In UTEX (583) (Starr, 1964). ATCC 29199 PCC 7111. J. B. Waterbury, hemispherical macroscopic colony, intertidal zone, Bodega, California, U.S.A., 1970.

ATCC 29111 PCC 7116. A. Neilson $\stackrel{\text { I }}{\leftarrow}$ R. A. Lewin, La Paz, Baja California, U.S.A., 1968. ATCC 29190 PCC 7204. J. B. Waterbury, hemispherical macroscopic colony, intertidal zone, Bodega, California, U.S.A., 1970.

ATCC 29157 PCC 7415. A. Neilson, soil, greenhouse, Stockholm, Sweden, 1972.

ATCC 29345 PCC 7426. J. B. Waterbury $\stackrel{\mathrm{I}}{\leftarrow}$ G. Guglielmi (Isactis sp.), flattened thallus on rock, intertidal zone, Banyuls-sur-Mer, France, 1974.

ATCC 29158 PCC 7504. $\stackrel{\text { I }}{\leftarrow}$ A. Neilson, fresh water aquarium, Stockholm, Sweden, 1972. ATCC 29112 PCC 7507. R. Rippka, sphagnum bog, near Kastanienbaum, Vierwaldstättersee, Switzerland, 1972.

The range of mean DNA base composition is 40 to $44 \mathrm{~mol} \% \mathrm{GC}$ (Herdman et al., 1979). Other strain properties are shown in Table 19. Hair formation, nominally typical for many Calothrix species (Bourrelly, 1970; Geitler, 1932), has recently been found to be dependent 

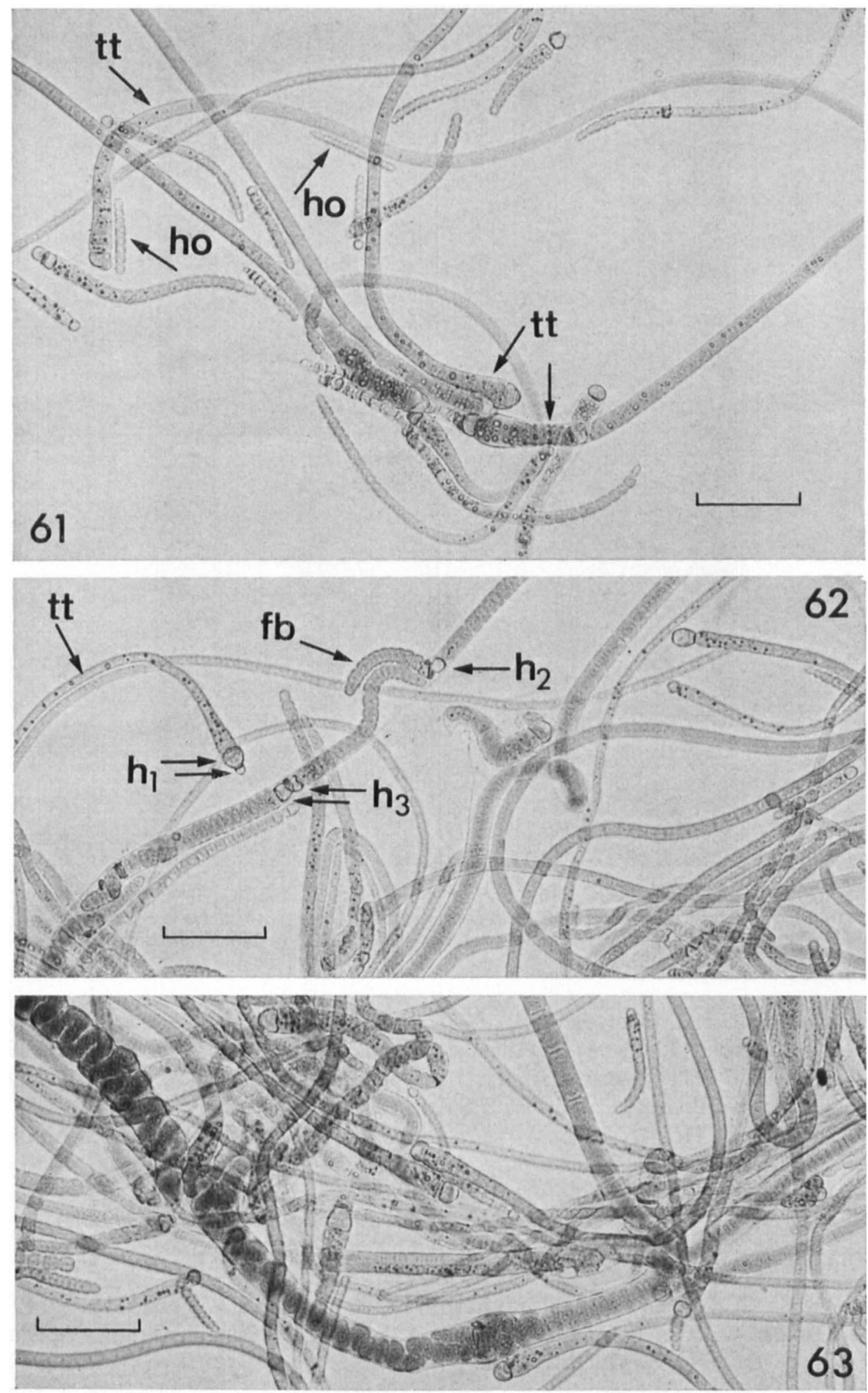

Figs 61 to 63. Calothrix PCC 7102. Fig. 61 shows the characteristic tapering of mature trichomes (tt) bearing basal heterocysts, aheterocystous hormogonia (ho) composed of cells of even width, and various stages of filament development. Fig. 62 shows a tapering trichome ( $\mathrm{tt}$ ) with two basal heterocysts $\left(\mathrm{h}_{1}\right)$ of markedly differing size, demonstrating the increase in cell width during the course of filament development. Also visible in this field are: false branching (fb) at the level of a terminal heterocyst $\left(h_{2}\right)$ within the trichome; and two terminal heterocysts $\left(h_{3}\right)$, which have differentiated on adjacent sides of a dead cell (necridium). Fig. 63 shows the coiling within a tightly enclosing sheath often found in Calothrix 7102, nominally distinctive for the genera Dichothrix and Polythrix. All bright field; bar markers represent $50 \mu \mathrm{m}$. 

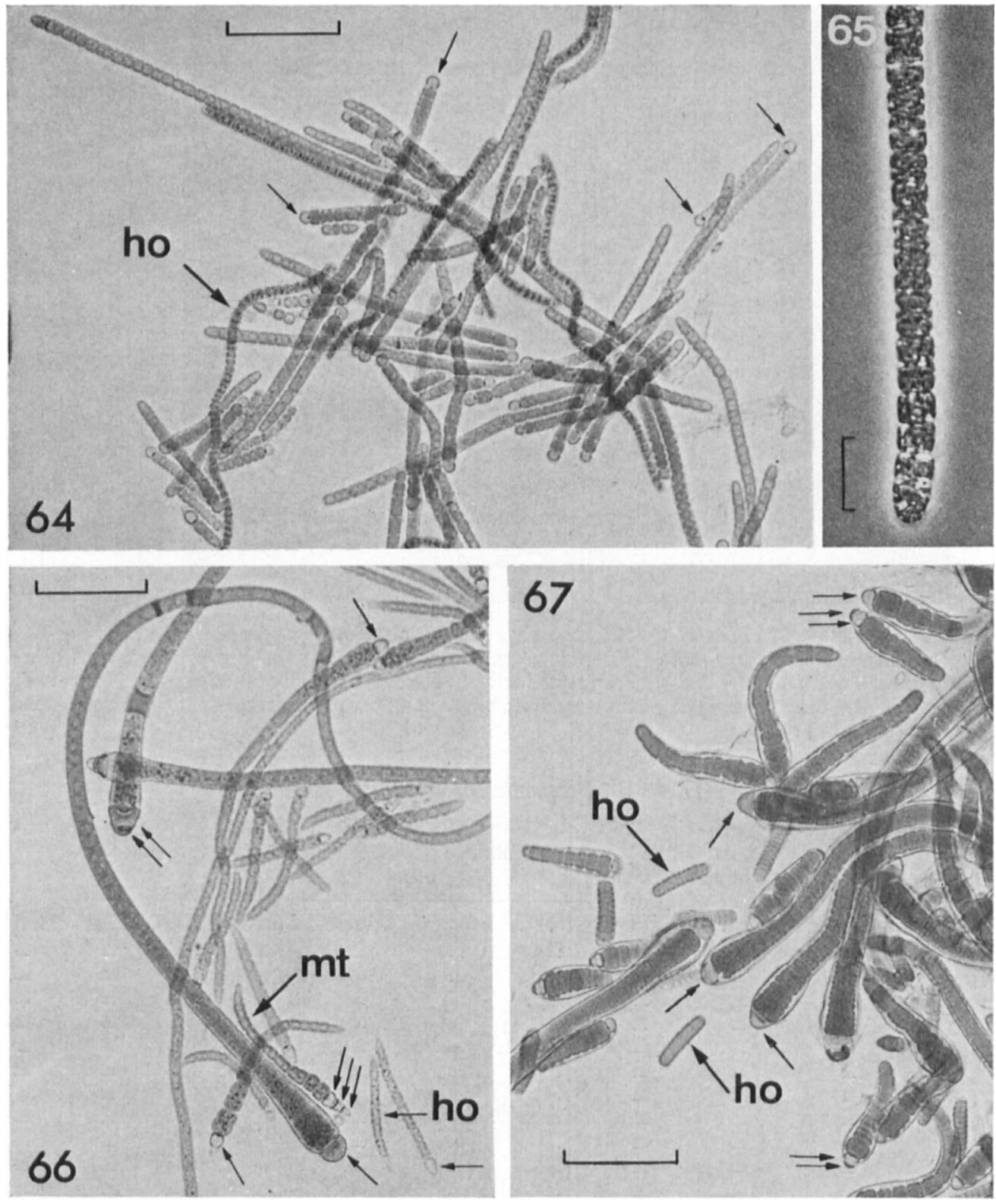

Figs 64 and 65. Calothrix PCC 7101 ('Tolypothrix tenuis', Watanabe, 1959). Fig. 64 shows the low degree of tapering of the mature trichomes, the exclusively terminal heterocysts (arrows) and the long gas-vacuolated hormogonia (ho). Bright field. Fig. 65 is an enlargement of a hormogonium, showing the irregularly distributed gas vacuoles typical of this strain. Phase contrast. Bar markers represent $50 \mu \mathrm{m}$ in Fig. 64 and $10 \mu \mathrm{m}$ in Fig. 65.

Fig. 66. Calothrix PCC 7103. Note the high degree of tapering of this strain, the aheterocystous hormogonia (ho) and the terminal heterocysts (arrows). One maturing trichome (mt) bears three terminal heterocysts of different sizes, demonstrating the increase of cell width during the course of successive heterocyst differentiation. Bright field; bar marker represents $50 \mu \mathrm{m}$.

Fig. 67. Calothrix PCC 7116. Note the sheathless aheterocystous hormogonia (ho) and the heavily ensheathed tapering trichomes that bear terminal heterocysts (arrows). Bright field; bar marker represents $50 \mu \mathrm{m}$. 

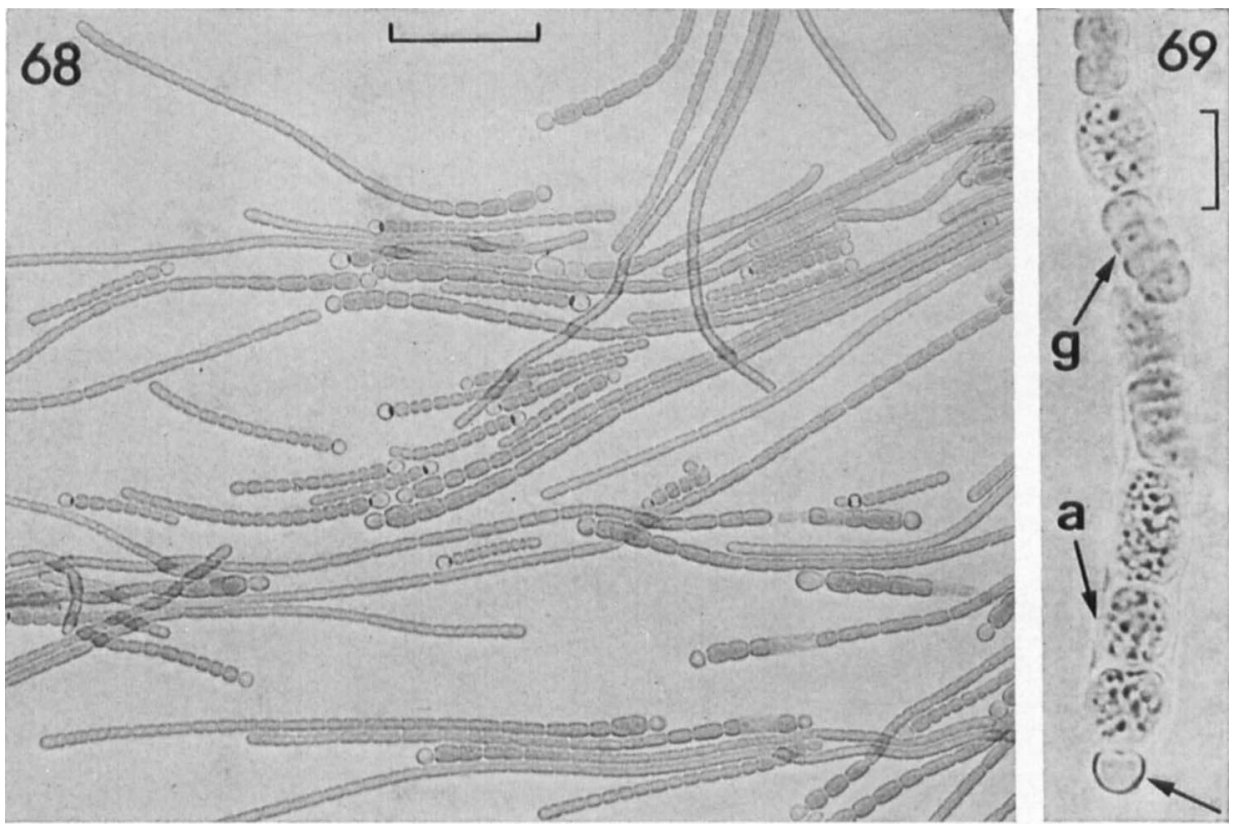

Figs 68 and 69. Calothrix PCC 7507, the only strain of this genus that produces akinetes. Fig. 68 shows the relatively low degree of tapering characteristic of this strain. Fig. 69 shows part of a mature filament bearing a basal heterocyst (arrow) adjacent to a chain of akinetes (a), several of which are in the course of germination (g). Both bright field; bar markers represent $50 \mu \mathrm{m}$ in Fig. 68 and $10 \mu \mathrm{m}$ in Fig. 69.

Table 19. Properties of Calothrix strains

\begin{tabular}{|c|c|c|c|c|c|c|c|c|c|c|}
\hline \multirow{2}{*}{$\begin{array}{l}\text { PCC } \\
\text { no.* }\end{array}$} & \multirow{2}{*}{$\begin{array}{l}\text { Hormo- } \\
\text { gonia } \\
\text { gas } \\
\text { vacuolated }\end{array}$} & \multirow{2}{*}{$\begin{array}{l}\text { Hetero- } \\
\text { cysts } \\
\text { sometimes } \\
\text { inter- } \\
\text { calary }\end{array}$} & \multirow{2}{*}{$\begin{array}{c}\text { Akinetes } \\
\text { pro- } \\
\text { duced }\end{array}$} & \multicolumn{4}{|c|}{$\begin{array}{l}\text { Facultative photoheterotroph, } \\
\text { using: }\end{array}$} & \multicolumn{2}{|c|}{$\begin{array}{l}\text { Synthesis } \\
\text { of: } \dagger\end{array}$} & \multirow[b]{2}{*}{ Marinet } \\
\hline & & & & Glucose & Fructose & Ribose & Sucrose & C-PE & PEC & \\
\hline 6303 & - & - & - & $-\S$ & - & - & + & + & - & - \\
\hline 7101$\}$ & + & - & - & + & + & + & - & + & - & - \\
\hline 7504$\}$ & + & + & - & + & + & + & - & + & - & - \\
\hline 7102 & - & - & - & + & + & - & - & - & - & - \\
\hline 7103 & - & - & - & + & + & - & + & + & - & - \\
\hline 7111 & - & - & - & + & $(+)$ & - & + & - & - & - \\
\hline 7116 & - & - & - & $(+)$ & $(+)$ & $(+)$ & + & - & + & + \\
\hline 204 & - & - & - & + & $(+)$ & - & + & - & + & - \\
\hline & - & + & - & + & + & - & + & + & - & - \\
\hline 20 & - & - & - & $(+)$ & $(+)$ & + & + & - & + & + \\
\hline 7507 & - & + & + & - & + & - & - & - & + & - \\
\hline
\end{tabular}

(+), Weak growth.

* Bracketed strains are probably independent isolates of the same species.

+ C-PE, C-phycoerythrin; PEC, phycoerythrocyanin.

* Requirement for high concentrations of $\mathrm{Na}^{+}, \mathrm{Mg}^{2+}$ and $\mathrm{Ca}^{2+}$.

$\S$ Although previously reported to grow on glucose (Kenyon et al., 1972), subsequent tests were always negative. 
on phosphate and iron deficiency (Whitton \& Sinclair, 1976) and is rarely observed under the culture conditions employed here. Although heterocysts are typically terminal in this genus, a few strains (PCC 7415, 7504 and 7507) produce rare intercalary heterocysts in longer trichomes. Only PCC 7507 has been observed to produce akinetes (Fig. 69); akinetes begin to develop adjacent to the terminal heterocyst, and may occur in chains. All 11 strains are heterotrophs, with differing patterns of sugar utilization. With the exception of PCC 7102 and 7111, all produce either C-phycoerythrin or phycoerythrocyanin. Only PCC 7101 and 7504 are sufficiently similar in both structural and physiological respects to suggest that they may be independent isolates of one species.

\section{Reference strain: PCC 7102}

\section{Genera of Section $V$}

The nine strains placed in this section are assigned to two genera: Fischerella Gomont 1895 and Chlorogloeopsis Mitra \& Pandey 1966, distinguished by the properties shown in Table 20 and Diagram 3.

Choice of the generic name Fischerella for the branched, filamentous strains of Section V, all of which are thermophiles, is based on the following considerations. A thermophilic cyanobacterium of this type was first described by Schwabe (1837) as Fischera thermalis. Cohn (1863) described in detail a similar organism from the same hot spring as Mastigocladus laminosus; creation of the new genus was justified primarily by smaller cell size. Since the name Fischera had previously been applied to a genus of higher plants, it was changed to Fischerella by Bornet \& Flahaut (1887), who reduced this taxon to a subgenus of Stigonema. Gomont (1895) once again elevated Fischerella to the generic level.

In subsequent phycological treatises (e.g. Geitler, 1932; Bourrelly, 1970), both Fischerella and Mastigocladus are recognized. However, the descriptions of the genus Mastigocladus presented are widely divergent and depart more or less extensively from the original description by Cohn (1863). The status of this genus consequently has now become very confused. For this reason, we have chosen to assign the branching filamentous strains of Section $\mathrm{V}$ to Fischerella Gomont 1895.

The structure and development of Chlorogloeopsis fritschii, type species of this monotypic genus, were well described by Mitra (1950), Fay et al. (1964) and by Mitra \& Pandey (1966). Recently, Evans et al. (1976) studied the effect of culture conditions on the morphology of Chlorogloeopsis fritschii (strain PCC 6912) and found that the filamentous phase of development is repressed under photoheterotrophic and chemoheterotrophic growth conditions. The ability of this heterocystous organism to divide in more than one plane precludes an assignment to Nostoc, which was suggested by Schwabe \& El Ayouty (1966). The significance of its division pattern was first recognized by Mitra \& Pandey (1966), who suggested inclusion of the new genus in the order Stigonematales, even though Chlorogloeopsis never displays the branched, filamentous structure characteristic for other members of this order. The placement of Chlorogloeopsis proposed by these authors is adopted here, since Section $\mathrm{V}$ is taxonomically equivalent to the phycological order Stigonematales.

The mean DNA base composition of the strains of Section V ranges from 42 to $46 \mathrm{~mol} \%$ GC (Herdman et al., 1979).

\section{Genus Fischerella Gomont 1895}

Six of the seven strains assigned to this genus were received as Mastigocladus sp. or Mastigocladus laminosus. The confusion surrounding the names Fischerella and Mastigocladus is discussed above. Three representative Fischerella strains are shown in Figs 70 to 78. The strain histories are as follows:

ATCC 27929 PCC 7115. $\stackrel{\text { P }}{\leftarrow}$ A. Neilson $\stackrel{\text { P }}{\leftarrow}$ F. Haxo (Mastigocladus sp. $\mathrm{H}_{2}$ ), thermal spring, Tassajara, California, U.S.A., 1971. 
Table 20. Section V: Filamentous heterocystous cyanobacteria that divide in more than one plane

\begin{tabular}{|c|c|c|}
\hline \multirow{2}{*}{$\begin{array}{l}\text { Reproduction by } \\
\text { random trichome } \\
\text { breakage, by } \\
\text { formation of } \\
\text { hormogonia and } \\
\text { (if produced) by } \\
\text { germination of } \\
\text { akinetes }\end{array}$} & $\begin{array}{l}\text { Hormogonia composed of small } \\
\text { cylindrical cells which enlarge } \\
\text { and become spherical; hetero- } \\
\text { cysts develop in terminal and } \\
\text { intercalary positions }\end{array}$ & $\begin{array}{l}\text { Cells in the mature trichome divide in } \\
\text { more than one plane; associated } \\
\text { detachment of groups of cells leads } \\
\text { to irregular Gloeocapsa-like aggre- } \\
\text { gates containing terminal hetero- } \\
\text { cysts; hormogonia are produced } \\
\text { within such aggregates } \\
\text { Chlorogloeopsis }\end{array}$ \\
\hline & $\begin{array}{l}\text { Hormogonia composed of small } \\
\text { cylindrical cells which enlarge and } \\
\text { become rounded; heterocysts } \\
\text { develop almost exclusively in an } \\
\text { intercalary position }\end{array}$ & $\begin{array}{l}\text { Cells in the mature trichome divide in } \\
\text { more than one plane to produce a } \\
\text { partly multiseriate trichome with } \\
\text { lateral uniseriate branches; hetero- } \\
\text { cysts in the primary trichome are } \\
\text { predominantly terminal or lateral; } \\
\text { hormogonia are produced from the } \\
\text { ends of trichomes or from lateral } \\
\text { branches } \\
\text { Fischerella }\end{array}$ \\
\hline
\end{tabular}

$\begin{array}{ccc}\text { Young } & \\ \text { Hormogonium } & \text { trichome } \quad \text { Culture in the mature state }\end{array}$
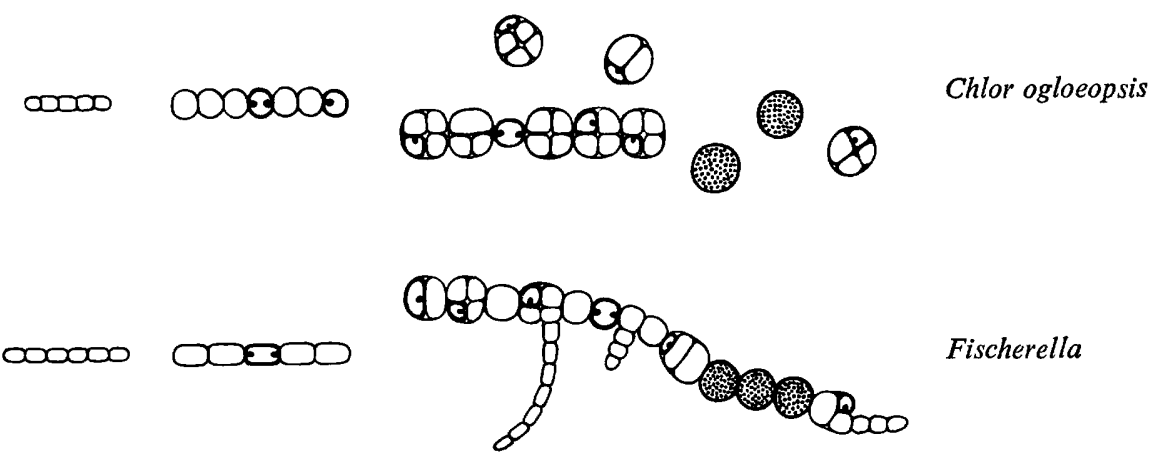

Diagram 3. Schematic presentation of the genera assigned to Section V. Heavy walled cells with polar granules represent heterocysts; heavy walled cells that are dotted represent akinetes; thin lines surrounding groups of cells designate sheath material.

ATCC 29114 PCC 73103. $\stackrel{\text { I }}{\leftarrow}$ SAUG $(1427 / 1)$ (Koch, 1964) $\leftarrow$ A. K. Mitra (Fischerella muscicola), rice field, near Allahabad, India (Mitra, 1951). In CCAP (1427/1) (Culture Collection of Algae and Protozoa: List of Strains, 1971) and UTEX (1301) (Starr, 1966).

ATCC 29161 PCC 7414. $\stackrel{\text { I }}{\leftarrow}$ SAUG $(1447 / 1) \leftarrow$ G. E. Fogg (Mastigocladus laminosus), hot spring, New Zealand. In CCAP (1447/1) (Culture Collection of Algae and Protozoa: List of Strains, 1971).

ATCC 29537 PCC 7520. $\stackrel{\mathrm{P}}{\leftarrow} \mathrm{R}$. Castenholz (Mastigocladus laminosus I-Kris-m), hot spring, Krisuvik, Iceland.

ATCC 29538 PCC 7521. $\stackrel{\mathrm{P}}{\leftarrow} \mathrm{R}$. Castenholz (Mastigocladus laminosus Y-16-m), hot spring, 

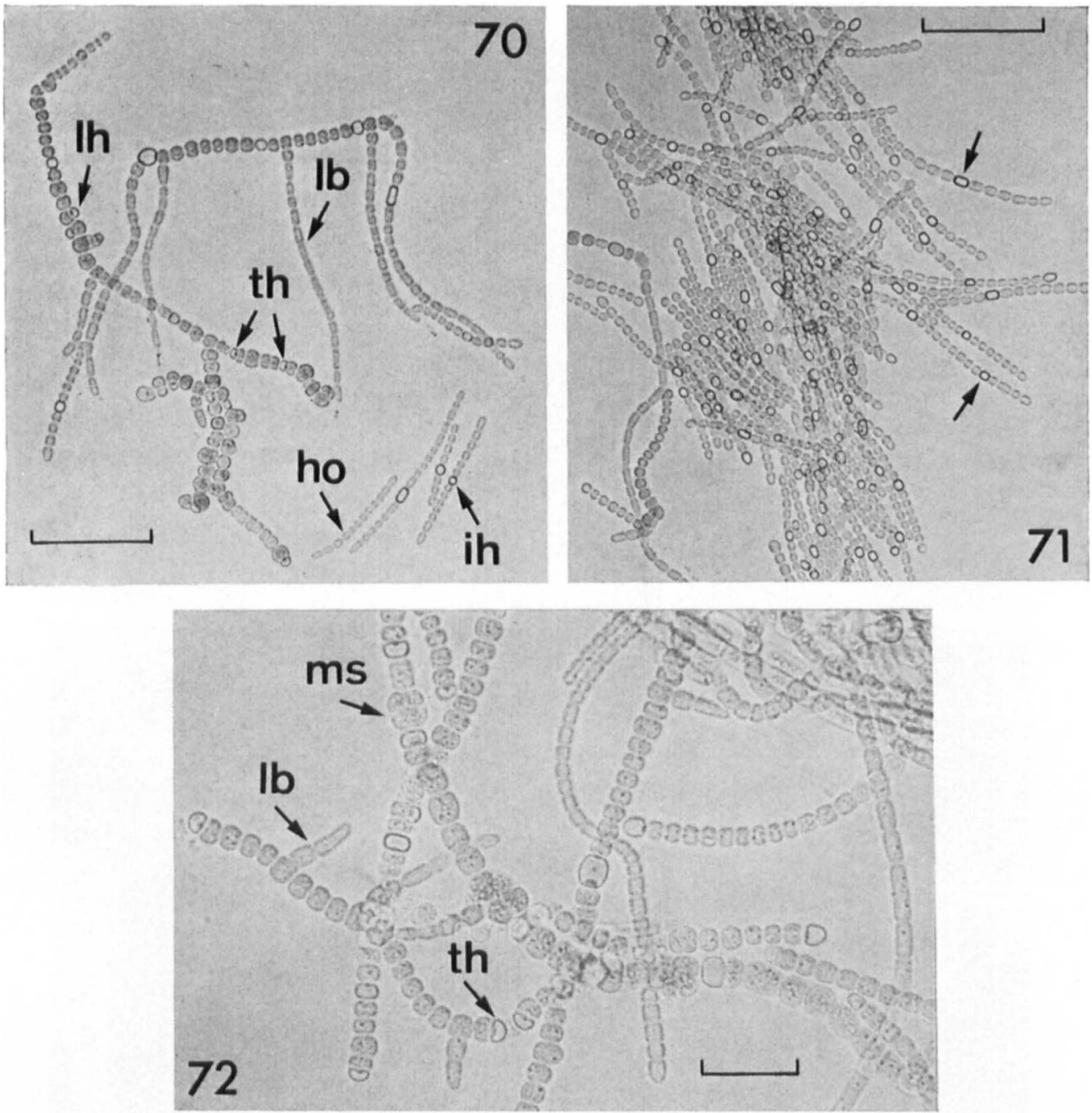

Figs 70 and 71. Fischerella PCC 7115. Fig. 70 shows mature trichomes with lateral branches (lb) from which hormogonia (ho) arise; heterocysts in the developing hormogonia are in an intercalary position (ih). The mature and partly multiseriate trichomes have intercalary heterocysts, terminal heterocysts (th) in an intercalary position, as well as lateral heterocysts (lh). Fig. 71 shows young trichomes composed of small cylindrical cells, with intercalary heterocysts (arrows). Both bright field; bar markers represent $50 \mu \mathrm{m}$.

Fig. 72. Fischerella PCC 7521 ('Mastigocladus laminosus' MTF, Y-16-m, Castenholz, 1969). Note the terminal heterocysts (th) in an intercalary position within the primary trichome, the lateral branches (lb) and multiseriate parts of the primary trichome (ms). Bright field; bar marker represents $20 \mu \mathrm{m}$.

Mammoth Sinkhole III, Yellowstone National Park, U.S.A., 1969 (Castenholz, 1969).

ATCC 29539 PCC 7522. $\stackrel{\text { P }}{\leftarrow}$ R. Castenholz (Mastigocladus laminosus NZ-86-m), hot spring, Whakarewarewa, New Zealand, 1969.

ATCC 29540 PCC 7523. $\stackrel{\text { P }}{\leftarrow}$ R. Castenholz (Mastigocladus laminosus OH-CW-m), hot spring, Oregon, U.S.A.

The mean DNA base composition of the Fischerella strains ranges from 42 to $46 \mathrm{~mol} \%$ GC (Herdman et al., 1979). The seven strains, despite their highly diverse geographical 

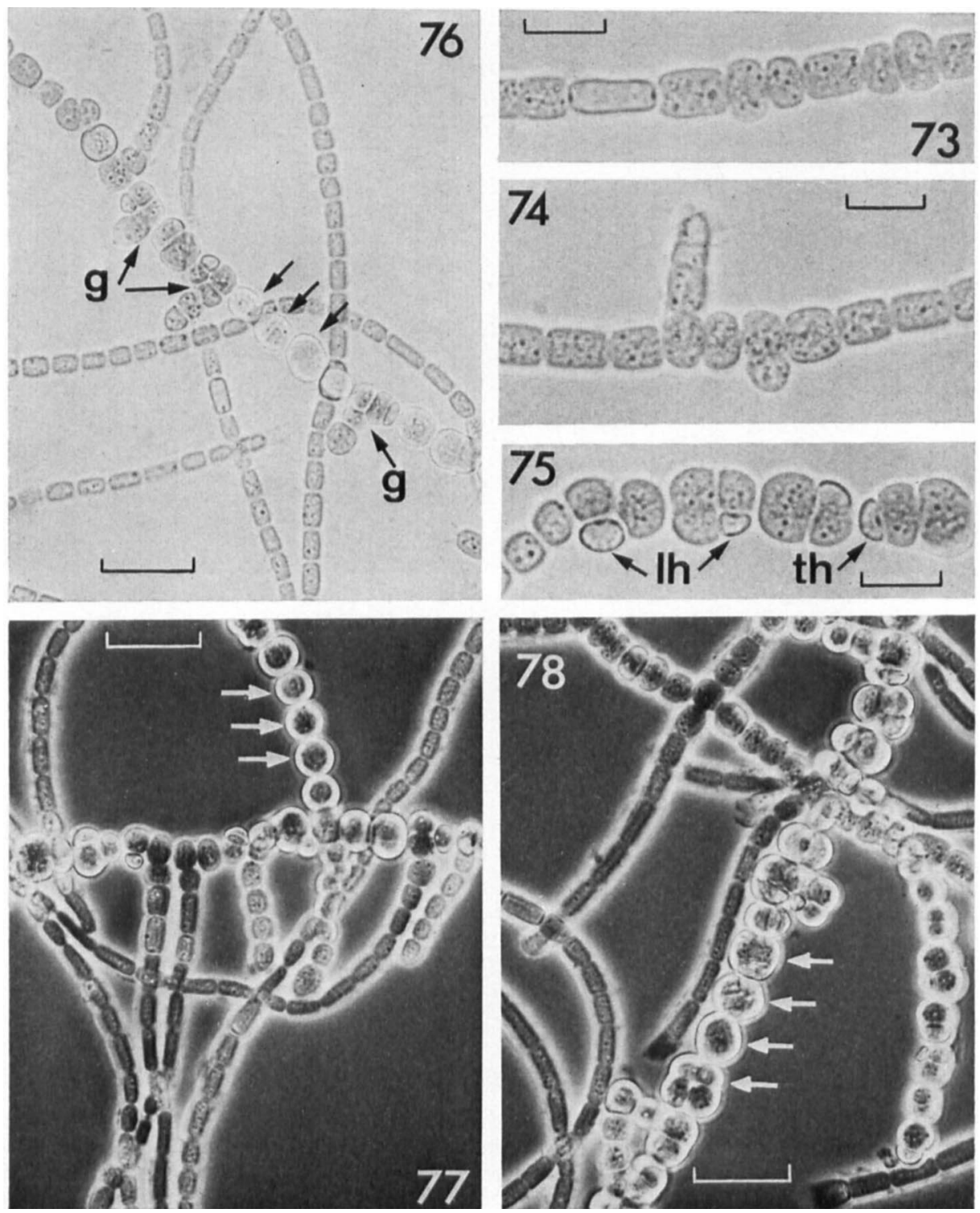

Figs 73 to 78 . Fischerella PCC 7414. Figs 73 and 74 show successive developmental stages in the formation of lateral branches: trichome just prior to branch formation (Fig. 73); lateral branches at the two-celled stage and at the four-celled stage (Fig. 74). Bright field. Fig. 75 shows part of a multiseriate trichome with lateral $(\mathrm{lh})$ and terminal (th) heterocysts. Note the distinctive gaps between groups of cells attributable to the intercellular deposition of a fibrous wall layer (Thurston \& Ingram, 1971). Bright field. Fig. 76 shows a mature filament with rows of akinetes (arrows), several of which are in the course of germination $(\mathrm{g})$ giving rise to lateral branches. Bright field. Figs 77 and 78 show comparable fields taken under phase contrast illumination to reveal more clearly the light refractile akinetes (arrows). Bar markers represent $10 \mu \mathrm{m}$ in Figs 73 to 75 and $20 \mu \mathrm{m}$ in Figs 76 to 78 . 

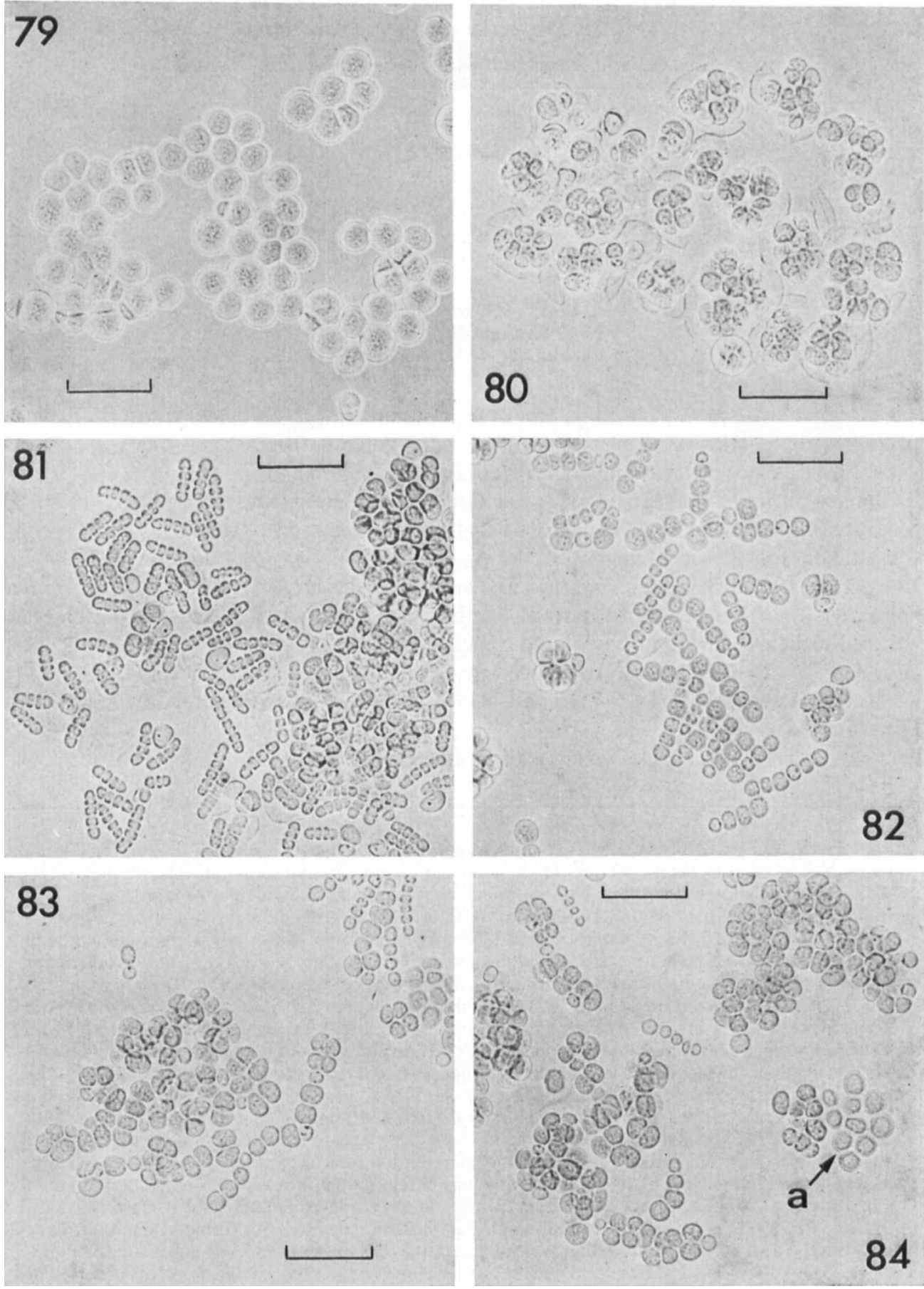

Figs 79 to 84. Developmental stages of Chlorogloeopsis fritschii PCC 6718. Fig. 79 shows a field of akinetes in a culture in late-stationary phase of growth. Fig. 80 shows the same culture several days after transfer to fresh medium. Akinete germination occurs by division in several planes and leads to a Gloeocapsa-like mode of growth. Note the shedding of the extra wall layers that enclosed the akinetes. Subsequent division of many cells in only one plane leads to massive production of short trichomes (hormogonia), that are composed of small cylindrical cells (Fig. 81). The development of hormogonia leads to the formation of trichomes of larger cell size and the differentiation of terminal and intercalary heterocysts (Fig. 82). Figs 83 and 84 show fields of cultures in early-stationary phase of growth, with young akinetes (a). All bright field; bar markers represent $20 \mu \mathrm{m}$. 
Table 21. Properties of Fischerella strains

\begin{tabular}{|c|c|c|c|c|c|c|c|}
\hline \multirow[b]{2}{*}{ PCC no. } & \multicolumn{4}{|c|}{ Facultative photoheterotroph, using: } & \multirow{2}{*}{$\begin{array}{l}\text { Akinetes } \\
\text { readily } \\
\text { evident }\end{array}$} & \multirow{2}{*}{$\begin{array}{c}\text { Synthesis } \\
\text { of } \\
\text { PEC }^{*}\end{array}$} & \multirow[b]{2}{*}{ Thermophil $\dagger$} \\
\hline & Glucose & Fructose & Ribose & Sucrose & & & \\
\hline 7115 & + & + & - & + & + & + & + \\
\hline 73103 & + & + & - & + & - & + & + \\
\hline 7414 & + & + & - & + & + & + & + \\
\hline 7520 & + & + & - & + & - & + & + \\
\hline 7521 & + & + & $(+)$ & + & - & + & + \\
\hline 7522 & + & + & + & - & - & + & + \\
\hline 7523 & + & + & + & + & - & + & + \\
\hline & & $\begin{array}{l}(+), W \\
* \text { PEC } \\
\dagger \text { Max }\end{array}$ & $\begin{array}{l}\text { growt } \\
\text { aycoery } \\
\text { Im grov }\end{array}$ & $\begin{array}{l}\text { ocyanin. } \\
\text { temperat }\end{array}$ & $50^{\circ} \mathrm{C}$. & & \\
\hline
\end{tabular}

origins, differ little in morphology, and appear similar in physiological respects (Table 21). All strains are facultative heterotrophs, growing on glucose, fructose and sucrose; some also utilize ribose. All synthesize phycoerythrocyanin.

Akinetes in Fischerella are not always readily recognizable (Martin \& Wyatt, 1974), and the large round cells of the primary trichome that are enclosed by the fibrous wall layer may be mistaken for young akinetes or vice versa. The only property (observable by light microscopy) that distinguishes mature akinetes from the large round cells of the primary trichome is their weaker pigmentation. Furthermore, since the germination of akinetes as well as the development of the round vegetative cells leads to the formation of lateral branches, the distinction between the two types of cells often becomes very difficult. Only two strains of Fischerella (PCC 7115 and 7414) form akinetes that can readily be recognized (Figs 76 to 78 ).

\section{Reference strain: PCC 7414}

Figs 85 to 99 . Details of the developmental stages of Chlorogloeopsis fritschii PCC 6718. Fig. 85 shows a field of akinetes. Figs 86 to 90 show the early stages in akinete germination. Uneven cell division in more than one plane without concomitant growth leads to the formation of cells of differing size. After the first uneven division, the daughter cell often differentiates into a heterocyst (arrow) (Fig. 87). However, heterocyst differentiation may also occur only after additional cell divisions, thus resulting in a heterocyst (arrow) of smaller size (Fig. 89). More than one heterocyst (arrows) per germinating akinete may occasionally be observed (Fig. 90). Fig. 91 shows two cell clusters that developed from akinetes by division in several planes (arrows indicate heterocysts). Note the extra cell wall layers of the original akinetes that surround both groups of cells. Fig. 92 shows division stages in only one plane by which a single cell produces a four- to six-celled hormogonium. At this stage of development, one observes a high frequency of heterocysts that are shed by the rapidly gliding aheterocystous hormogonia (Fig. 93, arrow; also see Fig. 81). Fig. 94 shows two filaments that developed from a hormogonium. Note the increase in cell size, the intercalary heterocysts (arrows) and a cell that is dividing in a plane parallel to the long axis of the trichome (d). Fig. 95 shows part of a maturing filament in which cell divisions have occurred parallel to the long axis of the trichome. One of the resulting cells has differentiated into a lateral heterocyst (arrow). Further cell division in several planes leads to trichomes composed of multicellular clusters as seen in Figs 96 to 99 . They may bear terminal, intercalary or lateral heterocysts. Terminal and intercalary heterocysts (Figs 96 to 99) differentiated from vegetative cells of the young and uniseriate trichomes (Fig. 94, but also see Fig. 82); lateral heterocysts developed only after cell divisions had occurred in planes other than that at right-angles to the long axis of the trichome. Trichomes as seen in Figs 96 to 99 easily fall apart into irregular cell aggregates and can readily be observed only after growth on solid medium. Fig. 99 shows strain PCC 6718 just prior to the breaking up of the trichomes and massive differentiation of akinetes (a). All bright field; bar marker (applicable to all figures) represents $10 \mu \mathrm{m}$. 

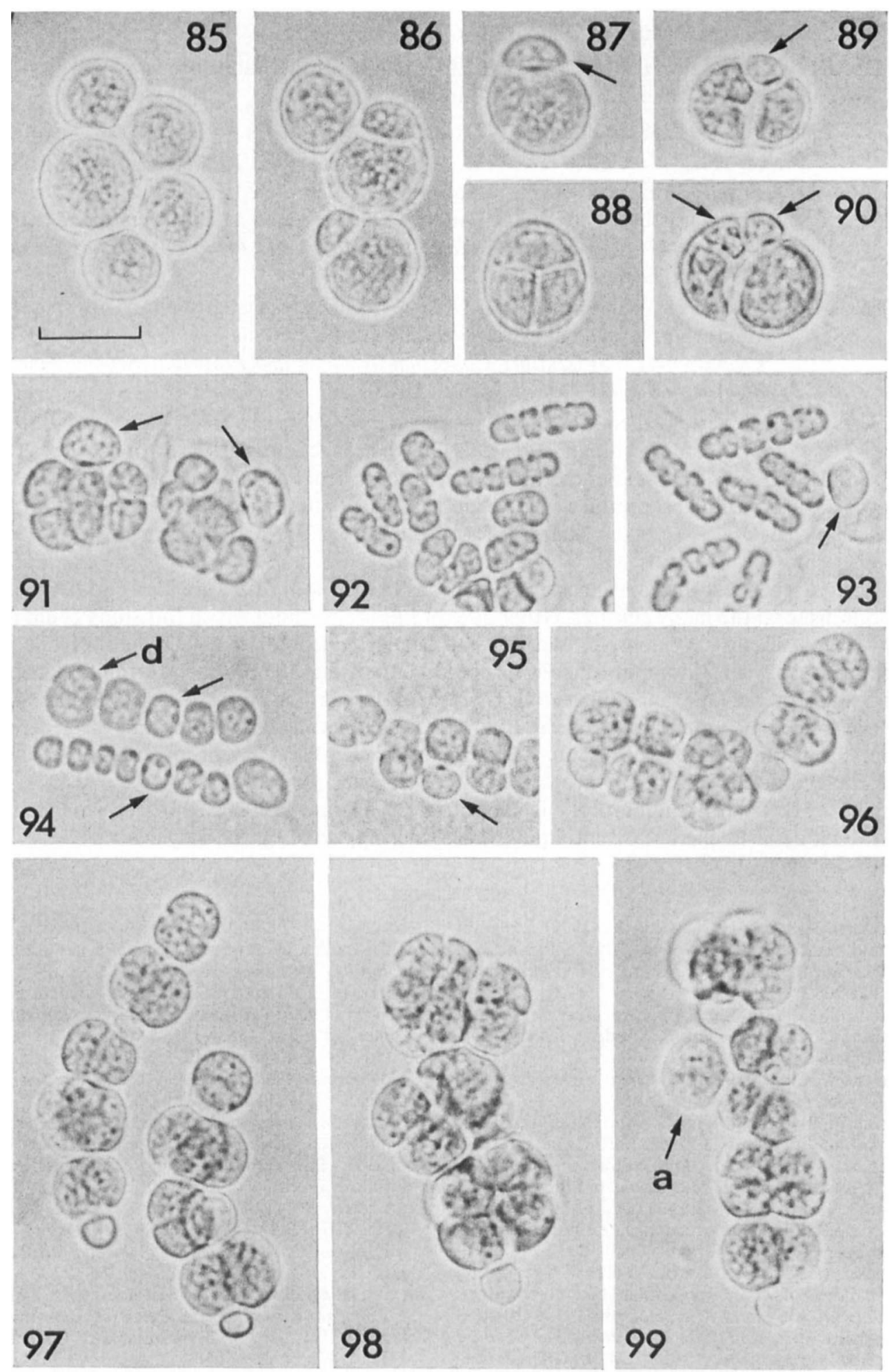


\section{Genus Chlorogloeopsis Mitra \& Pandey 1966}

Details of the development of one of the two strains in this genus are shown in Figs 79 to 99 . The histories of the strains are as follows:

ATCC 27193 PCC 6912 (Stanier et al., 1971; Kenyon et al., 1972). $\stackrel{\mathrm{P}}{\leftarrow}$ D. Hoare, University of Texas $\stackrel{\text { P }}{\leftarrow}$ CCAP $\stackrel{\text { P }}{\leftarrow}$ A. K. Mitra, soil sample, Allahabad, India (Mitra, 1950). Strain on which description of the type species, Chlorogloeopsis fritschii, is based (Mitra \& Pandey, 1966). Named as Chlorogloea fritschii in CCAP (1411/1) (Culture Collection of Algae and Protozoa: List of Strains, 1971) and SAUG (1411/1) (Koch, 1964).

ATCC 27181 PCC 6718 (Kenyon et al., 1972). $\stackrel{\text { I }}{\leftarrow}$ Botany Department, University of California, previous history unknown. Named as Chlorogloeopsis sp. in CCAP (1411/1b) (Culture Collection of Algae and Protozoa: Second Amendments to the 1971 List of Strains, 1973).

These two strains appear to be identical in all respects. The mean DNA base compositions are 42 to $43 \mathrm{~mol} \% \mathrm{GC}$ (Herdman et al., 1979). Both are facultative heterotrophs; they grow especially well with sucrose, but can also utilize glucose, fructose and ribose. Both synthesize phycoerythrocyanin and produce akinetes in stationary phase of growth.

\section{Reference strain: PCC 6912}

We wish to thank the colleagues, too numerous to mention, who were kind enough to put at our disposal the many cultures, either pure or impure, without which this study could not have been nearly so extensive. We are particularly indebted to Dr Donald Bryant for supplying us with still unpublished information concerning the phycoerythrinoid pigments of cyanobacteria. Our thanks also go to Thérèse Coursin for the preparation of the diagrams.

We are deeply grateful to $M$. Pierre Bourrelly for numerous discussions and for generous access to his library at the Museum d'Histoire Naturelle, Paris, even though his nihil obstat for the taxonomic part of this work is not necessarily acquired.

The work from our laboratory is supported by a grant (E.R.A. 398) from the Centre National de la Recherche Scientifique. M.H. was supported by the Royal Society.

\section{REFERENCES}

ADOLPH, K. W. \& HASELKoRN, R. (1971). Isolation and characterization of a virus infecting the blue-green alga Nostoc muscorum. Virology 46, 200-208.

AgardH, C. A. (1812). Dispositio Algarum Sueciae, D. IV, pp. 43-44, Lund, Sweden: Litteris Berlingianis.

AGARDH, C. A. (1824). Systema Algarum. Lund, Sweden: Litteris Berlingianis.

Agardh, J. G. (1842). Algae Maris Mediterranei et Adriatici, p. 8.Paris, France: Fortin, Masson et Cie.

Allen, M. B. (1952). The cultivation of Myxophyceae. Archiv für Mikrobiologie 17, 34-53.

ALleN, M. M. (1968). Simple conditions for growth of unicellular blue-green algae on plates. Journal of Phycology 4, 1-4.

Allen, M. M. \& Stanier, R. Y. (1968). Growth and division of some unicellular blue-green algae. Journal of General Microbiology 51, 199-202.

ANAGNosTIDIS, K. (1961). Untersuchungen über die Cyanophyceen einiger Thermen in Griechenland. Thessaloniki, Greece: Institut für Systematische Botanik und Pflanzengeographie der Universität, no. 7 .
Bornet, E. \& Flahaut, C. (1887). Révision des Nostocacées Hétérocystées. Annales des sciences naturelles (Botanique) 5, 51-129.

Bornet, E. \& Flahaut, C. $(1888 a)$. Note sur deux nouveaux genres d'algues perforantes. Journal de Botanique 2, 161-165.

Bornet, E. \& Flahaut, C. (1888b). Révision des Nostocacées Hétérocystées. Annales des sciences naturelles (Botanique) 7, 177-262.

Bory DE ST VINCENT, J. B. (1822). Anabaena. In Dictionnaire Classique d'Histoire Naturelle, vol. 1, p. 307. Paris, France: Rey \& Gravier, and Baudoin Frères.

Bourrelly, P. (1970). Les Algues d'Eau Douce. Tome III: Les Algues Bleues et Rouges. Les Eugléniens, Péridiniens et Cryptomonadines. Paris: Boubée.

BraUn, A. \& GRunow (1865). In Rabenhorst's Flora Europaea Algarum Aquae Dulcis et Submarinae, section II, pp. 148-149, Leipzig, Germany: Eduard Kummer.

Castenholz, R.W. (1969). The thermophilic cyanophytes of Iceland and the upper temperature limit. Journal of Phycology 5, 360-368. 
Castenholz, R. W. (1970). Laboratory culture of thermophilic cyanophytes. Schweizerische Zeitschrift für Hydrologie 32, 538-551.

Clements, F. E. \& Shantz, H. L. (1909). A new genus of blue-green algae. Minnesota Botanical Studies 4, 133-135.

CoHN, F. (1863). Über die Algen des Karlsbader Sprudels, mit Rücksicht auf die Bildung des Sprudelsinters. Abhandlungen der Schlesischen Gesellschaft für Vaterländische Kultur 2, 35-55.

Crouan, P. L. \& Crouan, H. M. (1858). Note sur quelques algues marines nouvelles de la rade de Brest. Annales des sciences naturelles (Botanique) 9, 69-75.

Culture Collection of Algae and Protozoa: List of Strains (1971). Cambridge: Culture Centre of Algae and Protozoa.

Culture Collection of Algae and Protozoa: SECOND AMENDMENTS TO THE 1971 LIST OF STRaIns (1973). Cambridge: Culture Centre of Algae and Protozoa.

Desikachary, T. V. (1959). Cyanophyta. New Delhi, India: Indian Council of Agricultural Research.

Desmazières, J. B. H. J. (1823). Catalogue des Plantes Omises dans la Botanographie Belge, et dans les Flores du Nord de la France. Lille, France: Leleux.

DYer, D. L. \& GAFFord, R. D. (1961). Some characteristics of a thermophilic blue-green alga. Science 134, 616-617.

Ercegovic, A. (1929). Sur quelques nouveaux types des cyanophycées lithophytes de la côte adriatique. Archiv für Protistenkunde 66, 164-174.

Evans, E. H., Foulds, I. \& Carr, N. G. (1976). Environmental conditions and morphological variation in the blue-green alga Chlorogloea fritschii. Journal of General Microbiology 92, 147155.

Fay, P., Kumar, H. D. \& FogG, G. E. (1964). Cellular factors affecting nitrogen fixation in the blue-green alga Chlorogloea fritschii. Journal of General Microbiology 35, 351-360.

FogG, G. E. (1942). Studies on nitrogen fixation by blue-green algae. I. Nitrogen fixation by Anabaena cylindrica Lemm. Journal of Experimental Biology 19, 78-87.

FogG, G. E., Stewart, W.D.P., Fay, P. \& WalsBy, A. E. (1973). The Blue-Green Algae, pp. 221-245. London: Academic Press.

Garlick, S., Oren, A. \& Padan, E. (1977). Occurrence of facultative anoxygenic photosynthesis among filamentous and unicellular cyanobacteria. Journal of Bacteriology 129, 623 $\rightarrow 629$.

Geitler, L. (1925). Synoptische Darstellung der Cyanophyceen in morphologischer und systematischer Hinsicht. Beihefte zum Botanischen Centralblatt 41, 163-294.

GeITLER, L. (1932). Cyanophyceae. In Rabenhorst's Kryptogamenflora von Deutschland, Österreich und der Schweiz, vol. 14. Edited by R. Kolkwitz. Leipzig, Germany: Akademische Verlagsgesellschaft.

GeITLER, L. (1933). Diagnosen neuer Blaualgen von den Sunda-Inseln. Archiv für Hydrobiologie Suppl. 12, 622-634.

Gerloff, G. C., Fitzgerald, G. P. \& Skoog, F.
(1950). The isolation, purification and nutrient solution requirements of blue-green algae. In Proceedings of the Symposium on the Culturing of Algae, pp. 27-44. Dayton, Ohio, U.S.A.: Charles F. Kettering Foundation.

Gerloff, G. C., Fitzgerald, G. P. \& Skoog, F. (1952). The mineral nutrition of Microcystis aeruginosa. American Journal of Botany 39, 26-32.

Ginzburg, D., Padan, E. \& Shilo, M. (1968). Effect of cyanophage infection on $\mathrm{CO}_{2}$ photoassimilation in Plectonema boryanum. Journal of Virology 2, 695-701.

Gomont, M. (1895). Note sur le Scytonema ambiguum Kütz. Journal de Botanique 9, 49-53.

HARDER, R. (1917). Ernährungsphysiologische Untersuchungen an Cyanophyceen, hauptsächlich dem endophytichen Nostoc punctiforme. Zeitschrift für Botanik 9, 149-242.

Hauck, F. (1885). Die Meeresalgen Deutschlands und Österreichs. In Rabenhorst's Kryptogamenflora von Deutschland, Österreich und der Schweiz, vol. 2, part 10. Leipzig, Germany: Eduard Kummer.

Herdman, M., JanVier, M., Waterbury, J. B., RIPPKA, R., STANiER, R. Y. \& MANDEL, M. (1979). Deoxyribonucleic acid base composition of cyanobacteria. Journal of General Microbiology 111, 63-71.

Hughes, E. O., Gorham, P. R. \& Zehnder, A. (1958). Toxicity of a unialgal culture of Microcystis aeruginosa. Canadian Journal of Microbiology 4, 225-236.

Kantz, T. \& Bold, H. C. (1969). Phycological Studies. IX. Morphological and Taxonomic Investigations of Nostoc and Anabaena in Culture. Publication no. 6924. Austin, U.S.A.: University of Texas.

Kelly, M. L. \& Cowie, D. B. (1971). DNA-DNA hybridization studies of blue-green algae. Yearbook of the Carnegie Institution of Washington 71, 276-281.

Kenyon, C. N., Rippka, R. \& Stanier, R. Y. (1972). Fatty acid composition and physiological properties of some filamentous blue-green algae. Archiv für Mikrobiologie 83, 216-236.

$\mathrm{KoCH}$, W. (1964). Verzeichnis der Sammlung von Algenkulturen am Pflanzenphysiologischen Institut der Universität Göttingen. Archiv für Mikrobiologie 47, 402-432.

KomareK, J. (1972). Reproduction process and taxonomy of unicellular endosporine blue-green algae. In Proceedings of the Symposium on Taxonomy and Biology of Blue-Green Algae, pp. 41-47. Edited by T. V. Desikachary. Madras, India: University of Madras.

KomAREK, J. (1976). Taxonomic review of the genera Synechocystis SAUV. 1892, Synechococcus NÄG. 1849, and Cyanothece gen.nov. (Cyanophyceae). Archiv für Protistenkunde 118, 119-179.

KomareK, J. \& HindaK, F. (1975). Taxonomy of new isolated strains of Chroococcidiopsis (Cyanophyceae). Archiv für Hydrobiologie Suppl. 46, 311-329.

Komarek, J., Ludvik, J. \& Pokorny, V. (1975). Cell structure and endospore formation in the blue-green alga Chroococcidiopsis. Archiv für Hydrobiologie Suppl. 46, 205-223. 
Kratz, W. A. \& MYers, J. (1955). Nutrition and growth of several blue-green algae. American Journal of Botany 42, 282-287.

KüTZING, F. T. (1833). Beitrag zur Kenntniss über die Entstehung und Metamorphose der niedern vegetabilischen Organismen, nebst einer systematischen Zusammenstellung der hierher gehörigen niedern Algenformen. Linnaea 8, 335-385.

KÜTzING, F. T. (1843). Phycologia Generalis, oder Anatomie, Physiologie und Systemkunde der Tange. Leipzig, Germany: F. A. Brockhaus.

LAMONT, H. C. (1969). Sacrificial cell death and trichome breakage in an oscillatoriacean bluegreen alga: the role of murein. Archiv für Mikrobiologie 69, 237-259.

Lapage, S. P., Sneath, P. H. A., Lessel, E. F., Skerman, V. B. D., Seeliger, H. P. R. \& Clark, W. A. (editors) (1975). International Code of Nomenclature of Bacteria. Washington, U.S.A.: American Society for Microbiology.

LAUTERBORN, R. (1915). Die sapropelische Lebewelt. Verhandlungen des Naturhistorisch-Medizinischen Vereins zu Heidelberg NF13, 437-438.

LAZARoff, N. (1966). Photoinduction and photoreversal of the nostocacean developmental cycle. Journal of Phycology 2, 7-17.

LAZAROFF, N. \& VishniaC, W. (1961). The effect of light on the developmental cycle of Nostoc muscorum, a filamentous blue-green alga. Journal of General Microbiology 25, 365-374.

LeACH, C. K. \& CARR, N. G. (1971). Pyruvate: ferredoxin oxidoreductase and its activation by A.TP in the blue-green alga Anabaena variabilis. Biochimica et biophysica acta 245, 165-174.

Le Campion-Alsumard, T. (1972). Quelques remarques sur la culture et le cycle de développement de la cyanophycée lithophyte: Hyella caespitosa Bornet et Flahaut. Tethys 4, 391-396.

LemmermanN, E. (1907). Die Algenflora der Chatham Islands. Englers Botanische Jahrbuch der Systematischen Pflanzengeschichte und Pflanzengeographie 38, 343-382.

MCCuRDY, H. D. (1974). The fruiting Myxobacteria. In Bergey's Manual of Determinative Bacteriology, 8 th edn, pp. 76-127. Edited by R. E. Buchanan \& N. E. Gibbons. Baltimore, U.S.A.: Williams \& Wilkins.

Martin, T. C. \& WYatT, J. T. (1974). Comparative physiology and morphology of six strains of stigonematacean blue-green algae. Journal of Phycology 10, 57-65.

Mertens, K. H. (1822). In Jürgens Algae Aquaticae, Decas XV, no. 4.

MeYen, F. J. F. (1839). Neues System der Pflanzenphysiologie, 3 Bände, 1837-1839. Berlin, Germany: Haude und Spenersche Buchhandlung.

Mitra, A. K. (1950). Two new algae from Indian soils. Annals of Botany 14, 457-464.

Mitra, A. K. (1951). The algal flora of certain Indian soils. Indian Journal of Agricultural Science 21, 357-373.

Mit'RA, A. K. \& PANDEY, D. C. (1966). On a new genus of the blue-green alga Chlorogloeopsis with remarks on the heterocysts in the alga. Phykos 5, 106-114.

Mollenhauer, D. (1970). Beiträge zur Kenntnis der
Gattung Nostoc. Abhandlungen hrsg. von der Senckenbergischen naturforschenden Gesellschaft 524, 1-80.

NÄGELI, C. (1849). Gattungen einzelliger Algen, physiologisch und systematisch bearbeitet. Neue Denkschriften der Allgemeinen schweizerischen Gesellschaft für die gesamten Naturwissenschaften 8, 44-60.

PAdan, E., Shilo, M. \& Kislev, N. (1967). Isolation of 'cyanophages' from freshwater ponds and their interaction with Plectonema boryanum. Virology 32, 234-246.

Pringsheim, E. G. (1951). Die Sammlung von Algen-, Flagellaten- und Mooskulturen am Botanischen Institut der Universität Cambridge. Archiv für Mikrobiologie 16, 1-17.

Pringsheim, E. G. (1966). Der Polymorphismus von Lyngbya kuetzingii. Kleine Mitteilungen über Flagellaten und Algen XI. Archiv für Mikrobiologie 53, 402-412,

Pringsheim, E. G. (1968). Cyanophyceen-Studien. Archiv für Mikrobiologie 63, 331-355.

Printz, H. (1921). Subaerial algae from South Africa. Kongelige Norske videnskabernes selskabs skrifter 1, 35-36.

Raboy, B., Padan, E. \& Shllo, M. (1976). Heterotrophic capacities of Plectonema boryanum. Archives of Microbiology 110, 77-86.

RIPPKA, R. (1972). Photoheterotrophy and chemoheterotrophy among unicellular blue-green algae. Archiv für Mikrobiologie 87, 93-98.

RIPPKA, R. \& STANIER, R. Y. (1978). The effects of anaerobiosis on nitrogenase synthesis and heterocyst development by nostocacean cyanobacteria. Journal of General Microbiology 105, 83-94.

RIPPKA, R. \& WATERBURY, J. B. (1977). The synthesis of nitrogenase by non-heterocystous cyanobacteria. FEMS Microbiology Letters 2, 83-86.

RippKa, R., Neilson, A., Kunisawa, R. \& CohenBAZIRE, G. (1971). Nitrogen fixation by unicellular blue-green algae. Archiv für Mikrobiologie 76, 341-348.

RipPKa, R., WATERbury, J. B. \& CohEN-BAzIRE, G. (1974). A cyanobacterium which lacks thylakoids. Archives of Microbiology 100, 419-436.

Róbinson, B. L. \& Miller, J. H. (1970). Photomorphogenesis in the blue-green alga Nostoc commune 584. Physiologia plantarum 23, 461-472.

Roth, A. W. (1802). Neue Beiträge zur Botanik I. Frankfurt, Germany: Friedrich Wilmans.

SAFFerman, R. S. \& Morris, M. F. (1963). Algal viruses: isolation. Science 140, 679-680.

SAFFerman, R. S. \& Morris, M. F. (1964). Control of algae with viruses. Journal of American Waterworks Association 56, 1217-1225.

Sauvageau, C. (1892). Sur les algues d'eau douce récoltées en Algérie. Bulletin de la Société botanique de France 39, 115-117.

SaUvageau, C. (1897). Sur le Nostoc punctiforme. Annales des sciences naturelles (Botanique) 8 , $366-378$.

SchwaBe, H. (1837). Ueber die Algen der Karlsbader warmen Quellen. Linnaea 11, 109-127.

Schwabe, G. H. (1960). Zur autotrophen Vegetation in ariden Böden. Blaualgen und Lebensraum IV. 
Österreichische botanische Zeitschrift 107, 281309.

Schwabe, G. H. \& El Ayouty, E. (1966). Über drei hormogonale Blaualgen aus indischen Böden. Nova Hedwigia 10, 527-536.

Stafleu, F. A., Bonner, C. E. B., McVaugh, R., Meikle, R. D., Rollins, R. C., Ross, R., Schopf, J. M., Schulze, G. M., DE Vilmorin, R. \& Voss, E. G. (editors) (1972). International Code of Botanical Nomenclature. Utrecht, The Netherlands: A. Oosthoek.

Stam, W. T. \& Venema, G. (1977). The use of DNA-DNA hybridization for determination of the relationship between some blue-green algae (Cyanophyceae). Acta botanica neerlandica 26, 327-342.

Stanier, R. Y. \& CohEn-Bazire, G. (1977). Phototrophic prokaryotes: the cyanobacteria. Annual Review of Microbiology 31, 225-274.

Stanier, R. Y., Kunisawa, R., Mandel, M. \& Cohen-Bazire, G. (1971). Purification and properties of unicellular blue-green algae (order Chroococcales). Bacteriological Reviews 35, 171205.

Stanier, R. Y., Sistrom, W. R., Hansen, T. A., Whitton, B. A., Castenholz, R. W., Pfennig, N., Gorlenko, V. N., Kondratieva, E. N., Eimhjellen, K. E., WhitTEnbury, R., GHerna, R. L. \& TRÜPER, H. G. (1978). Proposal to place the nomenclature of the cyanobacteria (bluegreen algae) under the rules of the International Code of Nomenclature of Bacteria. International Journal of Systematic Bacteriology 28, 335-336.

STARr, R. C. (1964). Culture collection of algae at Indiana University. Division Cyanophyta. American Journal of Botany 51, 1034-1035.

STARr, R. C. (1966). Culture collection of algae at Indiana University. Additions to the collection July 1, 1963 - July 1, 1966. Privately printed: Department of Botany, Indiana University, Bloomington, Indiana 47401, U.S.A.

STARr, R. C. (1971). Culture collection of algae at Indiana University. Additions to the collection July 1966 - July 1971. Journal of Phycology 7, 350-362.

Stevens, C. L. R. \& Myers, J. (1976). Characterization of pigment mutants in a blue-green alga, Anacystis nidulans. Journal of Phycology 12, 99105.

Stewart, W. D. P. \& LeX, M. (1970). Nitrogenase activity in the blue-green alga Plectonema boryanum strain 594. Archiv für Mikrobiologie 73, $250-260$

Stewart, W. D. P., Haystead, A. \& Pearson, H. W. (1969). Nitrogenase activity in heterocysts of blue-green algae. Nature, London 224, 226-228.

Stizenberger, E. (1852). Spirulina und Arthrospira (nov. gen.). Hedwigia 1, 32-34.
Thuret, G. (1844). Note sur le mode de reproduction du Nostoc verrucosum. Annales des sciences naturelles (Botanique) 2, 319-323.

Thuret, G. (1875). Essai de classification des nostochinées. Annales des sciences naturelles (Botanique) 1, 372-382.

THURET, G. (1880). Xenococcus schousboei. In Notes Algologiques, pp. 73-75. Edited by E. Bornet \& G. Thuret. Paris: G. Masson.

Thurston, E. L. \& Ingram, L. O. (1971). Morphology and fine structure of Fischerella ambigua. Journal of Phycology 7, 203-210.

TURPIN, P. J. F. (1827). Spiruline oscillarioïde. In Dictionnaire des Sciences Naturelles, vol. 50, pp. 309-310. Paris: F. G. Lévrault.

VAN BAalen, C. (1962). Studies on marine bluegreen algae. Botanica marina 4, 129-139.

VAN BAAlen, C. \& MARLER, J. E. (1963). Characteristics of marine blue-green algae with uric acid as nitrogen source. Journal of General Microbiology 32, 457-463.

VAucher, J. P. (1803). Histoire des Trémelles. In Histoire des Conferves d'Eau Douce. Genève, Switzerland: J. J. Paschoud.

WAaland, J. R. \& Branton, D. (1969). Gas vacuole development in a blue-green alga. Science 163, 1339-1341.

WAaland, J. R., WAaland, S. D. \& BRanton, D. (1970). Gas vacuoles. Light shielding in bluegreen algae. Journal of Cell Biology 48, 212-215.

Watanabe, A. (1959). Distribution of nitrogenfixing blue-green algae in various areas of South and East Asia. Journal of General and Applied Microbiology 5, 21-29.

Waterbury, J. B. \& Stanier, R. Y. (1977). Two unicellular cyanobacteria which reproduce by budding. Archives of Microbiology 115, 249-257.

WATERbury, J. B. \& STANIER, R. Y. (1978). Patterns of growth and development in pleurocapsalean cyanobacteria. Bacteriological Reviews 42, 2-44.

Whitton, B. A. \& Sinclair, C. (1976). Hair formation in the Rivulariaceae. Proceedings of the Second International Symposium on Photosynthetic Prokaryotes, p. 34-35. Edited by G. A. Codd \& W. D. P. Stewart. Dundee: University of Dundee.

WyatT, J. T. \& Silvey, J. K. G. (1969). Nitrogen fixation by Gloeocapsa. Science 165, 908-909.

ZANARDINI, J. (1858). Plantarum in mari rubro hucusque collectarum enumeratio. Memorie del Reale Istituto Veneto 7, 89.

ZANARDINI, J. (1872). Phycearum indicarum pugillus. Memorie del Reale Istituto Veneto 17, 32-33.

ZEHNDER, A. \& GoRHAM, P. R. (1960). Factors influencing the growth of Microcystis aeruginosa Kütz. emend. Elenkin. Canadian Journal of Microbiology 6, 645-660. 